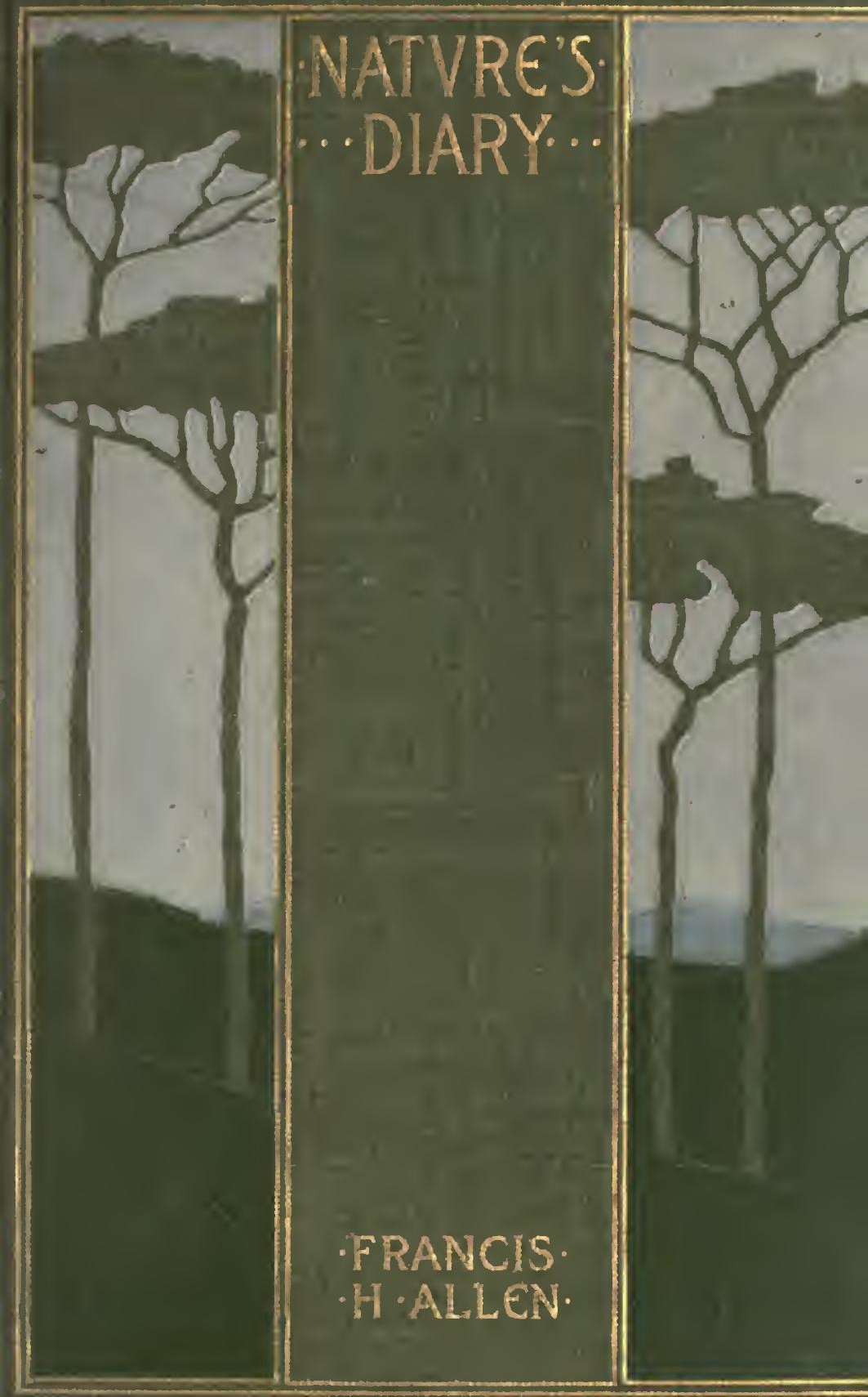



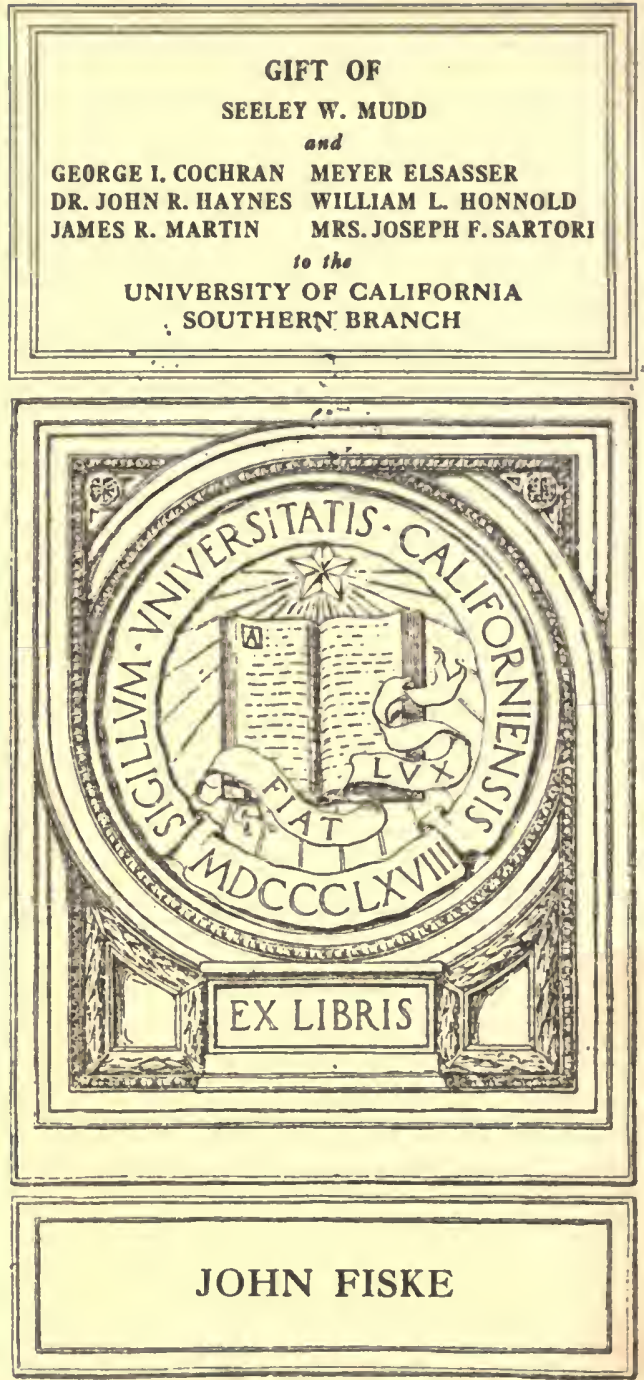
This book is DUE on the last date stamped below

NIV 27 1925) REC'D LD-URL

? NOV 191975

DEC \& $6 / 1013$

OEC $30^{\circ} 75$ 

Digitized by the Internet Archive in 2007 with funding from Microsoft Corporation 




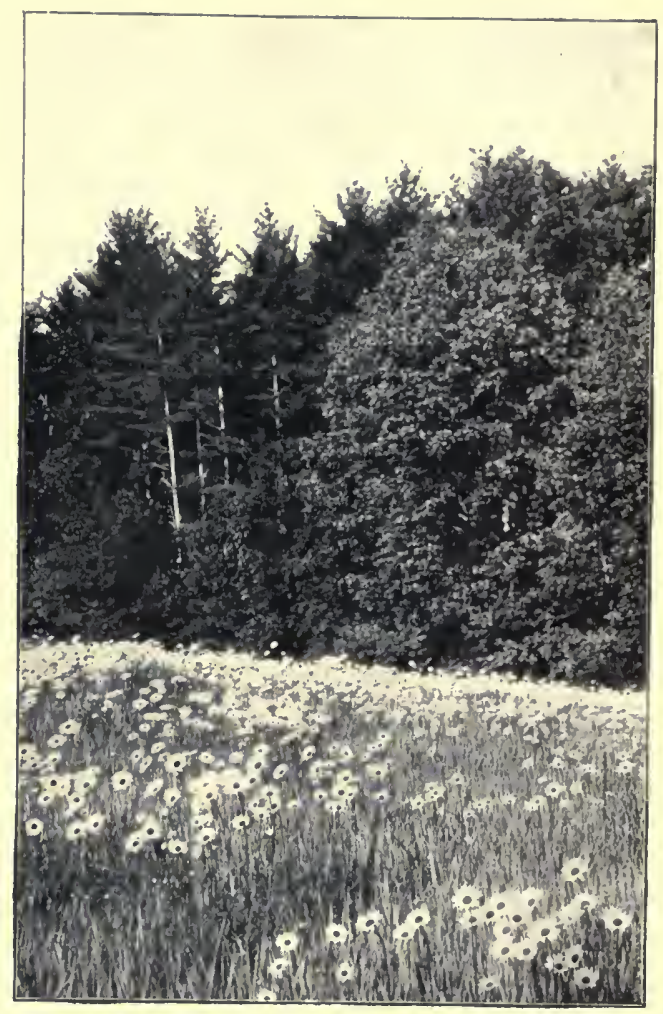




\title{
Nature's Diary
}

Compiled by

\author{
Francis H. Allen
}

"A minstrel of the ratural year

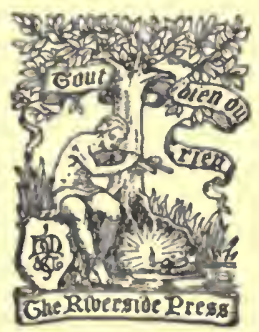

BOSTON AND NEW YORK HOUGHTON, MIFLIN AND COMPANY

Cbe tituergioe pregg, Cambroge

1898

$$
49836
$$


Copyright; 1897 ,

By HOUGHTON, MIFFLIN \& CO.

All rights reserved. 


\section{PREFACE}

IN labeling scientific specimens, the first and most important item is "locality;" and if this little book would make any pretentions to scientific methods, it must follow the rule. The first thing to be said, then, about these notes of Nature's is that they were made in the neighborhood of Boston. But they are not local in any exclusive sense, and so I think they will interest observers in all parts of the Northeastern States and even outside of that region.

I have tried to have each selection fit its day as exactly as possible, avoiding at the same time all generalities; and I feel quite sure that the reader will find no glaring incongruities or anachronisms (if I may so use the word), though it is more than likely that the exact average is not always hit upon. Every selection has passed a rigid examination upon two points, - scientific accuracy and poetic value, - so that neither requirement has been sacrificed to the other.

On the right-hand pages appears a calendar of the arrival of birds and the first blooming of flow- 
ers, with a few miscellaneous notes. The autumn dates for birds show the times of arrival of the more conspicuous migrants and winter visitors from the north. The dates given I believe to be very near the average; but Nature is, within limits, so variable and uncertain in her goings in and comings out, that we cannot expect her to follow this schedule with any regularity. The bluebird may come on the twenty-second of February or not for a month later; apple-trees may bloom on the tenth of May or wait until the twentieth. An early season or a late season is a consequence of favorable or unfavorable weather, either here or in some other region upon which we are dependent. We must not take the poet too literally when we read, -

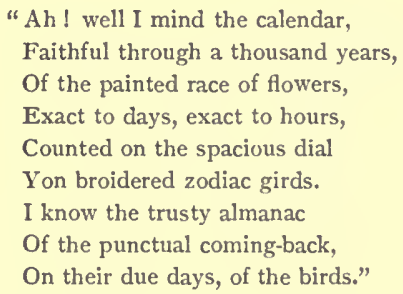

These days and hours are not to be reckoned by our own Gregorian calendar; but if we count them on a more spacious dial, we shall find the almanac of the birds and the flowers as trusty as Emerson found it. 
I know very well that I have omitted many birds and flowers that will be looked for by some persons, and I can only try to disarm criticism by apologizing in advance and by saying, once for all, that Nature's Diary is not in any sense a complete record of her doings.

For indispensable assistance in arranging the floral calendar, my thanks are due to the wellknown botanists Walter Deane, Esq., Frederick Le Roy Sargent, Esq., and Henry A. I'urdie, Esq. ; and I must also express my gratitude to William Brewster, Esq., and Henry M. Spelman, Esq., of Cambridge, Massachusetts, Professor Clarence Moores Weed of Durham, New Hampshire, Mr. and Mrs. White of North Conway, New Hampshire, and Robert Briggs Worthington, Esq., of Dedham, Massachusetts, for the use of the photographs from which the illustrations were made.

It is, perhaps, hardly necessary to suggest that the blank space on the right-hand pages may very appropriately be used for a perennial register of the progress of the seasons.

The preponderance of Thoreau in this little volume is due to the simple fact that his books really contain more quotable paragraphs than all the others together, and this is largely owing to his wonderfully picturesque and epigrammatic style.

$$
\text { F. H. A. }
$$





\section{LIST OF ILLUSTRATIONS}

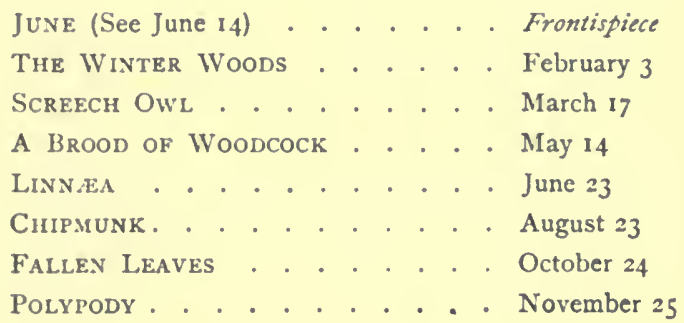





\section{NATURE'S DIARY}

Catch the pace of the seasons, have leisure to attend to every phenomenon of nature, and to entertain every thought that comes to you. Let your life be a leisurely progress through the realms of nature, even in guest-quarters.

Troreav: Winter.

$A$ book of the seasons, each page of which should be written in its own season and out of doors, or in its own locality, wherever it may be.

THoreav: Summer.

I want to go soon and live away by the pond where I shall hear only the wind whispering among the reeds. It will be success if I shall have left myself behind. But my friends ask what I will do when I get there! Will it not be employment enough to watch the progress of the seasons?

THOREAV: Winter. 


\section{JANUARY}

The chickadee is the bird of the wood the most unfailing. When in a windy or in any day you have penetrated some thick wood like this, you are pretty sure to hear its cheery note. At this season, it is almost its sole inhabitant. I see today one brown creeper busily inspecting the pitch pines. It begins at the base, and creeps rapidly upward by starts, adhering close to the bark, and shifting a little from side to side often till near the top, then suddenly darts off downward to the base of another tree, where it repeats the same course.

\section{Thoreau: Autumn.}

\section{2}

At no time of the year does the fellowship of the birds afford me keener enjoyment than in the dead of winter. In June one may see them everywhere, and hear them at all hours; a few more or a few less are nothing to make account of; but in January the sight of a single brown creeper is sufficient to brighten the day, and the twittering of half a dozen goldfinches is like the music of angels.

Torrey: A Rambler's Lease. 
JANUARY

I

2 


\section{JANUARY}

\section{3}

The crow may not have the sweet voice whic', the fox in his flattery attributed to him, but he has a good, strong, native speech nevertheless. How much character there is in it! How much thrift and independence ! . . Alert, social, republican, always able to look out for himself, not afraid of the cold and the snow, fishing when flesh is scarce, and stealing when other resources fail, the crow is a character I would not willingly miss from the landscape. I love to see his track in the snow or the mud, and his graceful pedestrianism about the brown fields.

Burroughs: Winter Sunshine.

\section{4}

Ah, the pickerel of Walden! When I see them lying on the ice, or in the well which the fisherman cuts in the ice, making a little hole to admit the water, I am always surprised by their rare beauty, as if they were fabulous fishes, they are so foreign to the streets, even to the woods, foreign as Arabia to our Concord life. . . . They are not green like the pines, nor gray like the stones, nor blue like the sky; but they have, to my eyes, if possible, yet rarer colors, like flowers and precious stones, as if they were the pearls, the animalized nuclei or crystals of the Walden water.

Thoreav: Walden. 
JANUARY

3

4 


\section{JANUARY}

5

In the pine woods the wind was less violent, but the passing snow seemed like vibrating white lines rather than flakes. As I stood in the pines and looked northeast, every tree was black against a distance of on-coming white rage. As I looked southwest every tree was white, finely outlined in black, against a retreating mass of colorless motion. If I looked southeast the trees were black and white, and if northwest they were white and black, and whichever way I looked the air was surging on, laden with the bewildered and bewildering snow.

BozLes: Land of the Lingering Snow.

\section{6}

The woods, which frost and November winds stripped of their leafy thatch, are roofed again, now with an arabesque of alabaster more delicate than the green canopy that summer unfolded, and all the floor is set in noiseless pavement, traced with a shifting pattern of blue shadows. In these silent aisles the echoes are smothered at their birth. ... The sound of the axe-stroke flies no farther than the pungent fragrance of the smoke that drifts in a blue haze from the chopper's fire. The report of the gun awakes no answering report, and each mellow note of the hound comes separate to the ear, with no jangle of reverberations.

Robrssox: In New England Fields and Woods. 
JANUARY

5

6 


\section{JANUARY}

\section{7}

There is a low mist in the woods. It is a good day to study lichens. The view so confined, it compels your attention to near objects, and the white background reveals the disks of the lichens distinctly. They appear more loose, flowing, expanded, flattened out, the colors brighter for the damp. The round, greenish-yellow lichens on the white pines loom through the mist (or are seen dimly) like shields whose devices you would fain read. The trees appear all at once covered with the crop of lichens and mosses of all kinds.

Thoreau : Winter.

\section{8}

Entering the pine woods where I had previously seen quail, I found the trees in trouble. The great pines were loaded down with ice, and many a branch had broken and fallen under its weight. The surface of the snow was strewn with twigs and branches of every size. A strange roar of falling ice and twigs filled the woods, now and then emphasized by the crash of some greater fall. I found the tracks of one quail and of a rabbit, made doubtless Saturday evening while the snow was still soft; but otherwise the face of the snow told no tales.

Bolles : Land of the Lingering Snow. 
JANUARY

7

8 


\section{JANUARY}

\section{9}

This poet, though he live apart, Moved by his hospitable heart, Sped, when I passed his sylvan fort, To do the honors of his court, As fits a feathered lord of land, Flew near, with soft wing grazed my hand, Hopped on the bough, then, darting low, Prints his small impress on the snow, Shows feats of his gymnastic play, Head downward, clinging to the spray.

Emerson: The Titmouse.

\section{IO}

There is but little life and the objects are few, it is true. We are reduced to admire buds, even like the partridges, and bark, like the rabbits and mice, the great red and forward looking buds of the azalea, the plump red ones of the blueberry, and the fine sharp red ones of the panicled andromeda sleeping along its stem, the speckled black alder, the rapid growing dogwood, the pale brown and cracked blueberry, etc. Even a little shining bud which lies sleeping behind its twig, perhaps half concealed by ice, is object enough.

Thoreav: Winter. 
JANUARY

9

IO 


\section{JANUARY}

\section{I}

'The sunsets of winter are incomparably splendid; and when the ground is covered with snow, no brilliancy of tint expressible by words can come within an infinite distance of the effect. Our southern view at that time, with the clouds and atmospherical hues, is quite indescribable; . . . the various distances of the hills which lie between us and the remote dome of Taconic are brought out with an accuracy unattainable in summer. The transparency of the air at this season has the effect of a telescope in bringing objects apparently near, while it leaves the scene all its breadth.

HAwthorve: American Note-Books.

The solitary pine, unhindered, symmetrical, green to its lowermost twig, as it rises out of the meadow or stands a-tiptoe on the rocky ledge, is a thing of beauty, a pleasure to every eye. A pity and a shame that it should not be more common! But the pine forest, dark, spacious, slumberous, musical! Here is something better than beauty, dearer than pleasure. When we enter this cathedral, unless we enter it unworthily, we speak not of such things. Every tree may be imperfect, with half its branches dead for want of room or want of sun, but until the devotee turns critic - an easy step, alas, for half-hearted worshipers - we are conscious of no lack.

Torrey: The Foot-Path Way. 
JANUARY

I I

12 


\section{JANUARY}

I 3

But few birds about. Apparently their granaries are locked up in ice, with which the grasses and buds are coated. Even far in the horizon the pine tops are turned to fir or spruce by the weight of the ice bending them down, so that they look like a spruce swamp. ... I see some oaks in the distance, which, from their branches being curved and arched downward and massed, are turned into perfect elms, which suggests that this is the peculiarity of the elm. Few if any other trees are thus wisp-like, the branches gracefully drooping.

THOREAU: Winter.

\section{4}

Several times I heard crows, fying through the driving snow, calling to each other in its confusion. In the pines at the summit of the first high hill were two little brown creepers flying from trunk to trunk and exploring busily the bark on the sheltered side of the trees. When they left a tree the storm whirled them away like dry leaves, but they promptly headed toward the wind and sped back under the lee of some sheltering tree to its butt, the point where their explorations always begin. They kept track of each other by frequent attenuated squeaks.

Bolles: Land of the Lingering Snow. 


\section{JANUARY}

13

14 


\section{JANUARY}

\section{5}

And when I returned new drifts would have formed, through which I floundered, where the busy northwest wind had been depositing the powdery snow round a sharp angle in the road, and not a rabbit's track, nor even the fine print, the small type, of a meadow mouse was to be seen. Yet I rarely failed to find, even in midwinter, some warm and springy swamp where the grass and the sliunk-cabbage still put forth with perennial verdure, and some hardier bird occasionally awaited the return of spring.

Thoreau : Walden.

\section{6}

No winter day, as it seems to me, was ever so fair as the winter night with the moon presiding. Not for the eye of the sun are the finer, subtler wonders of the snow; these are reserved for the celestial wanderer "with white fire laden." So well pleased is she with the faithful coldness and purity of the snow that she is constantly visiting it with favors. Therefore are her nameless gem-bearing mountains and her treasure-houses laid under contribution for the adormment of her terrestrial love, in the folds of whose garments a myriad jewels sparkle.

Edity M. Thomas : The Round Year. 
JANUARY

15

16 


\section{JANUARY}

\section{7}

Going by the ... oak at Clam-shell Hill bank, I heard a faint rippling note, and looking up saw about fifteen snow buntings sitting in the top of the oak, all with their breasts toward me. Sitting so still, and quite white seen against the white cloudy sky, they did not look like birds, and their boldness, allowing me to come quite near, enhanced this impression. . . . It was a very spectral sight, and after I had watched them for several minutes I can hardly say that I was prepared to see them fly away like ordinary buntings when I advanced further.

Thoreau: Early Spring in Massachusetts.

\section{8}

The suow was lighter than chaff. It had been dried in the Arctic ovens to the last degree. The foot sped through it without hindrance. I fancied the grouse and quails quietly sitting down in the open places, and letting it drift over them. With head under wing, and wing snugly folded, they would be softly and tenderly buried in a few moments. The mice and the squirrels were in their dens, but I fancied the fox asleep upon some rock or log, and allowing the flakes to cover him. The hare in her form, too, was being warmly sepulchred with the rest. I thought of the young cattle and the sheep huddled together on the lee side of a haystack in some remote field, all enveloped in mantles of white.

Burrovghs: Sigus and Seasons. 
JANUARY

I 7

18 


\section{JANUARY}

\section{9}

I see some tree sparrows feeding on the fine grass-seed above the snow. They are flitting along one at a time, commonly sunk in the snow, uttering occasionally a low, sweet warble, and seemingly as happy there, and with this wintry prospect before them for the night and several montlis to come, as any man by his fireside. One occasionally hops or flies toward another, and the latter suddenly jerks away from him. ... At length the whole ten have collected within a space a dozen feet square, but soon after, being alarmed, they utter a different and less musical chirp, and fit away into an apple-tree.

Troreav: Winter.

\section{0}

Adown the slopes there are tiny rivulets, which exist only for the winter. Bare, brown spaces of grass here and there, but still so infrequent as only to diversify the scene a little. In the woods, rocks emerging, and, where there is a slope inmediately towards the lake, the snow is pretty much gone, and we see partridge-berries frozen, and outer shells of walnuts, and chestnut-burrs, heaped or scattered among the roots of the trees. The walnut-husks mark the place where the boys, after nutting, sat down to clear the walnuts of their outer shell.

Hawthonke: American Note-Books. 
JANUARY

19

20 


\section{JANUARY}

\section{I}

The tracks of partridges are more remarkable in this snow than usual, it is so light, being, at the same time, a foot deep. ... I see where many have dived into the snow, apparently last night, on the side of a shrub oak hollow. In four places they have passed quite underneath it for more than a foot; in one place, eighteen inches. They appear to have dived or burrowed into it, then passed along a foot or more underneath, and squatted there, perhaps with their heads out. . . . I scared one from its hole only half a rod in front of me, now at 11 A.M.

Troneau: Winter.

\section{2}

Most of our birds are yet essentially wild, that is, little changed by civilization. . . . The pine grosbeaks will come in numbers upon your porch to get the black drupes of the honeysuckle or the woodbine, or within reach of your windows to get the berries of the mountain-ash, but they know you not; they look at you as innocently and unconcernedly as at a bear or moose in their native north, and your house is no more to them than a ledge of rocks.

Burroughs: Signs and Seasons. 
JANUARY

21 


\section{JANUARY}

\section{3}

The value of the pitch pine in winter is that it holds the snow so finely. I see it now afar on the hillsides decking itself with it, its whited towers forming coverts where the rabbit and the gray squirrel lurk. It makes the most cheerful winter scenery, beheld from the window, you know so well the nature of the coverts and the sombre light it makes. The young oaks with their red leaves, covering so many acres, are also an indispensable feature of the winter landscape, and the limbs of oak woods where some of the trees have been cut off.

THoReav: Winter.

\section{4}

Through my north window, in the wintry weather, -

My airy oriel on the river shore, -

I watch the sea-fowl as they flock together

Where late the boatman flashed his dripping oar.

The gull, high floating, like a sloop unladen,

Lets the loose water waft him as it will; 'The duck, round-breasted as a rustic maiden,

Paddles and plunges, busy, busy still.

Holmes: My Aviary. 
JANUARY

23

24 


\section{JANUARY}

25

When I see a fox run across the pond on the snow, with the carelessness of freedom, or at intervals trace his course in the sunshine along the ridge of a hill, I give up to him sun and earth as to their true proprietor. He does not go in the sun, but it seems to follow him, and there is a visible sympathy between him and it. Sometimes, when the snow lies light, and but five or six inches deep, you may give chase and come up with one on foot. In such a case he will show a remarkable presence of mind, choosing only the safest direction, though he may lose ground by it.

Thoreav: Natural History of Massachusetts.

\section{6}

The long trumpet-like bay, heard for a mile or more, - now faintly back to the deep recesses of the mountain, - now distinct, but still faint, as the hound comes over some prominent point and the wind favors, - anon entirely lost in the gully, - then breaking out again much nearer, and growing more and more pronounced as the dog approaches, till, when he comes around the brow of the mountain, directly above you, the barking is loud and sharp. On he goes along the northern spur, his roice rising and sinking as the wind and the lay of the ground modify it, till lost to hearing. Burroughs: Winter Sunshine. 
JANUARY

25

26 


\section{JANUARY}

\section{7}

The sky was a cold grayish white; the pines and cedars looked almost black. Against the sky the ice-covered, leafless trees were a darker gray than the clouds, but against the evergreens or in masses by themselves they were ashes-of-roses color and wonderfully soft in tone. Looking across a sloping pasture at a swamp filled with elms and willows, they seemed to be a mass of dark stems with their tops shrouded in pale smoke through which the faintest possible fire-glow permeated. I suppose the color came from the reddish bark of the twigs. Bolles: Land of the Lingering Snow.

\section{8}

As I flounder along the Corner road against the root fence, a very large flock of snow buntings alight with a wheeling flight amid the weeds rising above the snow ... a hundred or two of them. They run restlessly amid the weeds, so that I can hardly get sight of them through my glass. Then suddenly all arise and fly only two or three rods, alighting within three rods of me. They keep up a constant twittering. It is as if they were ready any instant for a longer flight, but their leader had not so ordered it. Suddenly away they sweep again, and $I$ see them alight in a distant field where the weeds rise above the snow, but in a few minutes they have left that also, and gone farther north.

Thoreav: Winter. 
JANUARY

27

28 


\section{JANUARY}

\section{9}

The sharp-rayed track of the partridge adds another figure to this fantastic embroidery upon the winter snow. Her course is a clear, strong line, sometimes quite wayward, but generally very direct, steering for the densest, most impenetrable places, - leading you over logs and through brush, alert and expectant, till, suddenly, she bursts up a few yards from you, and goes humming through the trees, - the complete triumph of endurance and vigor. Hardy native bird, may your tracks never be fewer, or your visits to the birch-tree less frequent.

Burrovghs: Winter Sunshine.

\section{0}

Saw and heard cheep faintly one little tree sparrow, the neat chestnut-crowned and winged, and white-barred bird, so clean and tough, made to withstand the winter. This color reminds one of the upper side of the shrub-oak leaf. . . I I love the few homely colors of Nature at this season, her strong, wholesome browns, her sober and primeval grays, her celestial blue, her vivacious green, her pure cold snowy-white. Thus Nature feeds her children cheaply with color. I have no doubt that it is an important relief to the eyes which have long rested on snow, to rest on brown oak leaves and the bark of trees.

Thoreav: Autumn. 
JANUARY

29

30 


\section{JANUARY}

\section{1}

Winter, too, is, on the whole, the triumphant season of the moon, a moon devoid of sentiment, if you choose, but with the refreshment of a purer intellectual light, - the cooler orb of middle life. Who ever saw anything to match that gleam, rather divined than seen, which runs before her over the snow, a breath of light, as she rises on the infinite silence of winter night? High in the heavens, also, she seems to bring out some intenser property of cold with her chilly polish.... As you walk homeward, - for it is time that we should end our ramble, - you may perchance hear the most impressive sound in nature, unless it be the fall of a tree in the forest during the hush of summer noon. It is the stifled shriek of the lake yonder as the frost throttles it.

LowELL: A Good Word for Winter. 
JANUARY

3 I 


\section{FEBRUARY}

The scream of the jay is a true winter sound. It is wholly without sentiment, and in harmony with winter. - I stole up within five or six rods of a pitch pine behind which a downy woodpecker was pecking. From time to time he hopped round to the side towards me, and observed me without fear. They are very confident birds, not easily scared, but incline to keep the other side of the bough from you, perhaps.

Thoreau: Winter.

It is a maze of twistings and turnings, but it is a tell-tale track nevertheless, for only the partridge can set such an exquisite pattern. If you follow it a bit, you will notice where it has disappeared in the snow, leaving a sort of blur at the end of this line so beautifully written. If the bird had mounted into the air for a flight, the sentence would have been cut short, but here is a bit of punctuation that is not found in the books. The partridge has started upon a burrowing expedition, a subterranean journey, as it were, under the snow.

Sylvester : Homestead Highways. 
FEBRUARY

I

2

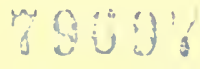




\section{FEBRUARY}

\section{3}

The snow has fallen so gently that it forms an upright wall on the slenderest twig. The agreeable maze which the branches make is more obvious than ever, and every twig thus laden is as still as the hillside itself. . . The effect of the snow is to press down the forest, confound it with the grasses, and create a new surface to the earth above, shutting us in with it, and we go along somewhat like moles through our galleries. The sight of the pure and trackless road up Brister's Hill, with branches and trees supporting snowy burdens bending over it on each side, would tempt us to begin life again.

Thoreav: Winter.

4

What a very gymnast is the typical chickadee! As he twists himself on his perch, bringing his head under his feet, I am reminded of similar grotesque actions in the parrot. How tame and curious, hopping down through the branches, until just above one's head! There is a winnowing sound in the flight of the chickadee which recalls the rustling noise of the humming-bird's wings, or the night-moth hovering over flowers, in the faraway antipode of the season. Responsive to this sweetest note heard in all winterdom comes the terse staccato "yah, yah," of the fellowshiping nuthatches.

Edith M. Thomas: From Winter Solstice to Vernal Equinox. 


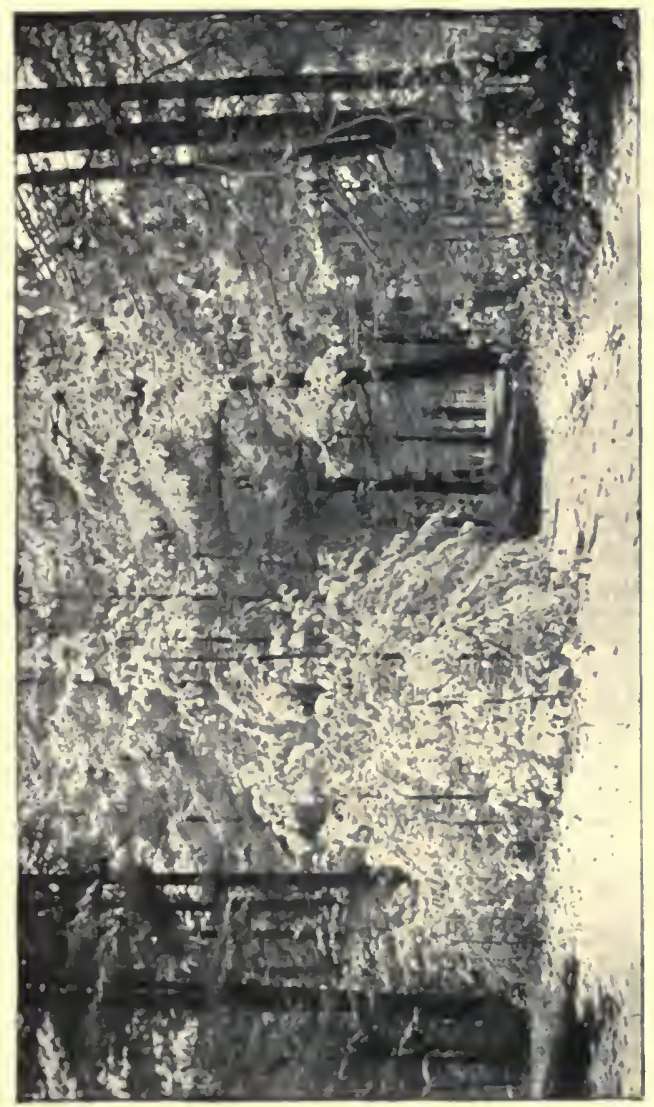





\section{FEBRUARY}

3

4 


\section{FEBRUARY}

\section{5}

I frequently see three or four old white birches standing together on the edge of a pond or meadow, and am struck by the pleasing manner in which they will commonly be grouped, how they spread so as to make room for each other, and make an agreeable impression upon the eye.

THoReav: Winter.

The tints of the sunset sky are never purer and more ethereal than in the coldest winter days. This evening, though the colors are not brilliant, the sky is crystalline, and the pale fawn-tinged clouds are very beautiful.

Thoreau: Winter.

\section{6}

However, when you do get a crust that will bear, and know any brooklet that runs down a hillside, be sure to go and take a look at him, especially if your crust is due, as it commonly is, to a cold snap following eagerly on a thaw. You will never find him so cheerful. As he shrank away after the last thaw he built for himself the most exquisite caverns of ice to run through, if not "measureless to man" like those of Alph, the sacred river, yet perhaps more pleasing for their narrowness than those for their grandeur.

LOWELL: A Good Word for Winter. 
FEBRUARY

5

6 


\section{FEBRUARY}

\section{7}

A little family of titmice gathered about me searching for their food both on the ground and on the trees with great industry and intentness, now and then pursuing each other. There were two nuthatches at least talking to each other. One hung with his head down on a large pitch pine pecking the bark for a long time, leaden blue above with a black cap and a white breast. ... A downy woodpecker with the red spot on his hind head and his cassock open behind, showing his white robe, kept up an incessant loud tapping on another pitch pine.

Thoreav: Winter.

8

Judged by the eye alone, the fox is the lightest and most buoyant creature that runs. His soft wrapping of fur conceals the muscular play and effort that is so obvious in the hound that pursues him, and he comes bounding along precisely as if blown by a gentle wind. His massive tail is carried as if it floated upon the air by its own lightness.

Burrovghs: Pepacton.

The snow buntings and the tree sparrows are the true spirits of the snow-storm. They are the animated beings that ride upon it and have their life in it.

Thoreav: Winter. 


\section{FEBRUARY}

7

8 


\section{FEBRUARY}

9

I hear a fine, busy twitter, and looking up, see a nuthatch hopping along and about a swamp white oak branch, inspecting every side of it, as readily hanging head downwards as standing upright, and then it utters a distinct quah, as if to attract a companion. Indeed, that other finer twitter seemed designed to keep some companion in tow, or else it was like a very busy man talking to himself. The companion was a single chickadee, which lisped six or eight feet off. There were perhaps no other birds than these within a quarter of a mile. When the nuthatch? flitted to another tree two rods off, the chickadee unfailingly followed.

Thorenv: Winter.

IO

Summer has few finer pictures than this winter one of the farmer foddering his cattle from a stack upon the clean snow, - the movement, the sharply defined figures, the great green flakes of hay, the long file of patient cows, the advance just arriving and pressing eagerly for the choicest morsels, and the bounty and providence it suggests. Or the chopper in the woods, - the prostrate tree, the white new chips scattered about, his easy triumph over the cold, coat hanging to a limb, and the clear, sharp ring of his axe. The woods are rigid and tense, keyed up by the frost, and resound like a stringed instrument.

Burrovghs: Winter Sunshine. 


\section{FEBRUARY}

9

10 


\section{FEBRUARY}

\section{I}

In the winter, warmth stands for all virtue, and we resort in thought to a trickling rill, with its bare stones shining in the sun, and to warm springs in the woods, with as much eagerness as rabbits and robins. ... What fire could ever equal the sunshine of a winter's day, when the meadow mice come out by the wall-sides, and the chickadee lisps in the defiles of the wood? The warmth comes directly from the sun, and is not radiated from the earth, as in summer; and when we feel his beams on our backs as we are treading some snowy dell, we are grateful as for a special kindness, and bless the sun which has followed us into that by-place.

Thoreav: A Winter Walk.

\section{2}

DARWIN, 1809.

Those little ruby-crowned lesser redpolls still about. They suddenly flash away from this side to that, in flocks, with a tumultuous note, half gurgle, half rattle, like nuts shaken in a bag, or a bushel of nutshells, soon returning to the tree they had forsaken on some alarm. They are oftenest seen on the white birch, apparently feeding on its seeds, scattering the scales about.

Thoreav: Autumn. 
FEBRUARY

I I

I 2 


\section{FEBRUARY}

\section{3}

Chickadees were everywhere, and very noisy. They worked quite as much on snow-covered twigs as on the sheltered side of branches. In the cedar swamp they popped in and out of snow caverns among the branches, often tipping over great piles of snow and dodging them with a jolly "chick-adee-dee-dee."

Bolles: Land of the Lingering Snow.

There is no winter necessarily in the sky, though snow covers the earth. The sky is always ready to answer to our moods. We can see summer there or winter.

Thoreau: Winter.

\section{I4}

The woods roar, the waters shine, and the hills look invitingly near. You do not miss the flowers and the songsters, or wish the trees or the fields any different, or the heavens any nearer. Every object pleases. A rail fence, running athwart the hills, now in sunshine and now in shadow, - how the eye lingers upon it! Or the straight, lightgray trunks of the trees, where the woods have recently been laid open by a road or a clearing, how curious they look, and as if surprised in undress! Next year they will begin to shoot out branches and make themselves a screen.

Burroughs: Winter Sunshine. 
FEBRUARY

13

14 


\section{FEBRUARY}

\section{5}

In February another track appears upon the snow, slender and delicate, about a third larger than that of the gray squirrel, indicating no haste or speed, but, on the contrary, denoting the most imperturbable ease and leisure, the footprints so close together that the trail appears like a chain of curiously carved links. Sir Mephitis mephitica, or, in plain English, the skunk, has woke up from his six weeks' nap, and come out into society again. ... There is no such word as hurry in his dictionary, as you may see by his path upon the snow.

Berrovghs: Winter Sunshine.

\section{I6}

The pond began to boom about an hour after sunrise, when it felt the influence of the sun's rays slanted upon it from over the hills; it stretched itself and yawned like a waking man with a gradually increasing tumult, which was kept up three or four hours. It took a short siesta at noon, and boomed once more toward night, as the sun was withdrawing his influence. In the right stage of the weather a pond fires its evening gun with great regularity.

Thoreau: Walden. 
FEBRUARY

15

16 


\section{FEBRUARY}

\section{7}

I find that it is an excellent walk for variety and novelty and wildness to keep round the edge of the meadow. The ice not being strong enough to bear, and transparent as water, on the bare ground or snow just between the highest water mark and the present water line is a narrow, meandering walk rich in unexpected views and objects. The line of rubbish which marks the higher tides, withered flags and seeds and twigs and cranberries, is to my eyes a very agreeable and significant line which nature traces along the edge of the meadows.

Thoreav: Winter.

\section{8}

Presently a fox barks away up next the mountain, and I imagine I can almost see him sitting there, in his furs, upon the illuminated surface, and looking down in my direction. As I listen, one answers him from behind the woods in the valley. What a wild winter sound, wild and weird, up among the ghostly hills! Since the wolf has ceased to howl upon these mountains, and the panther to scream, there is nothing to be compared with it. So wild! I get up in the middle of the night to hear it. It is refreshing to the ear, and one delights to know that such wild creatures are among us.

Burroughs: Winter Sunshine. 


\section{FEBRUARY}




\section{FEBRUARY}

19

See a large flock of snow buntings, the white birds of the winter, rejoicing in the snow. I stand near a flock in an open field. They are trotting about briskly over the snow, amid the weeds, apparently pig-weed and Roman wormwood, as if to keep their toes warm hopping up to the weeds. Then they suddenly take to wing again, and as they wheel about one, it is a very rich sight to see them dressed in black and white uniforms, alternate black and white, very distinct and singular.

Thoreav: Early Spring in Massachusetts.

\section{0}

If you are sick and despairing, go forth in winter and see the red alder catkins dangling at the extremity of the twigs all in the wintry air, like long, hard mulberries, promising a new spring and the fulfillment of all our hopes. We prize any tenderness, any softening in the winter, catkins, birds' nests, insect life, etc. The most I get, perchance, is the sight of a mulberry-like red catkin, which I know has a dormant life in it seemingly greater than my own.

Thoreav: Winter. 


\section{FEBRUARY}

19

20 


\section{FEBRUARY}

2 I

Entering the woods, the number and variety of the tracks contrast strongly with the rigid, frozen aspect of things. Warm jets of life still shoot and play amid this snowy desolation.... The mice tracks are very pretty, and look like a sort of fantastic stitching on the coverlid of the snow. One is curious to know what brings these tiny creatures from their retreats; they do not seem to be in quest of food, but rather to be traveling about for pleasure or sociability, though always going posthaste, and linking stump with stump and tree with tree by fine, hurried strides.

Burroughs: Winter Sunshine.

James Russell Lowell, 1819.

Those trees and shrubs which retain their withered leaves through the winter, shrub oaks, and young white, red, and black oaks, the lower branches of larger trees of the last-mentioned species, hornbeams, young hickories, etc., seem to form an intermediate class between deciduous and evergreen trees. They may almost be called the ever-reds. Their leaves, which are falling all winter long, serve as a shelter to rabbits and partridges, and other winter birds and quadrupeds. Even the chickadees love to skulk amid them, and peep out from behind them.

Thoread: Autumn. 
FEBRUARY

21

22 


\section{FEBRUARY}

\section{3}

Look up or down the open river channel now so smooth. Like a hibernating animal, it has ventured to come out to the mouth of its burrow. One way, perhaps, it is like melted silver alloyed with copper. It goes nibbling off the edge of the thick ice on each side. Here and there I see a musquash sitting in the sun on the edge of the ice, eating a clam, and the shells it has left are strewn along the edge. Ever.and anon he drops into the liquid mirror and soon reappears with another clam.

Thoreau: Early Spring in Massachusetts.

\section{4}

The sunshine, the bracing air, the swaying boughs of the pines and hemlocks beckoning at the woodside, and the firm smooth footing, irresistibly invite you forth. Your feet devour the way with crisp bites, and you think that nothing could be more pleasant to them till you are offered a few yards of turf, laid bare by winds and sun, and then you realize that nothing is quite so good as the old stand-by, a naked ground, and crave more of it, even as this is, and huuger for it with its later garnishing of grass and flowers.

Robinson: In New England Fields and Woods. 
FEBRUARY

23

24 


\section{FEBRUARY}

25

We pause and gaze into the Mill brook on the Turnpike bridge. I see a good deal of cress there on the bottom for a rod or two, the only green thing to be seen. ... . Is not this the plant which most, or most conspicuously, preserves its greenness in the winter ? . . It is as green as ever, and waving in the stream as in summer.

Thoreav: Winter.

A chickadee, with its winter lisp, flits over. I think it is time to hear its phœebe note, and that instant it pipes it forth.

ThOREAU: Early Spring in Massachusetts.

\section{6}

Now look down from your hillside across the valley. The trees are leafless, but this is the season to study their anatomy, and did you ever notice before how much color there is in the twigs of many of them?

Lowell: A Good Word for Winter.

This afternoon, as probably yesterday, it being warm and thawing, though fair, the snow is covered with snow fleas. Especially they are sprinkled like pepper for half a mile in the tracks of a woodchopper in deep snow. With the first thawing weather they come. 
FEBRUARY

25

26 


\section{FEBRUARY}

\section{7}

I hear faintly the cawing of a crow far, far away, echoing from some unseen woodside, as if deadened by the spring-like vapor which the sun is drawing from the ground. It mingles with the slight murmur of the village, the sound of children at play, as one stream empties gently into another, and the wild and tame are one. What a delicious sound! It is not merely crow calling to crow, for it speaks to me too. I am part of one great creature with him. If he has voice, I have ears. I can hear when he calls, and have engaged not to shoot or stone him, if he will caw to me each spring.

Thoreau: Winter.

\section{8}

Scare up a rabbit on the hillside by these ponds, which was gnawing a smooth sumach. See also where they have gnawed the red maple, sweet fern, Populus grandidentata, white and other oaks (taking off considerable twigs at four or five cuts), amelanchier, and sallow. But they seem to prefer the smooth sumach to any of them. With this variety of cheap diet they are not likely to starve. The rabbit, indeed, lives, but the sumach may be killed. I get a few drops of the sweet red-maple juice which has run down the main stem where a rabbit has nibbled a twig off close.

Thoreau: Farly Spring in Massachusetts. 


\section{FEBRUARY}

27

28 


\section{FEBRUARY}

\section{9}

I hear the well-known note and see a flock of Fringilla hiemalis, ${ }^{1}$ flitting in a lively manner about trees, weeds, walls, and ground by the roadside, showing their two white tail-feathers. They are more fearless than the song-sparrow. They attract notice by their numbers and incessant twittering in a social manner.

Thoreav: Early Spring in Massachusetts.

Twice this winter I have noticed a muskrat floating in a placid, smooth, open place in the river, when it was frozen for a mile each side, looking at first like a bit of stump or frozen meadow, but showing its whole upper outline from nose to end of tail, perfectly still till he observed me, then suddenly diving and steering under the ice toward some cabin's entrance or other retreat halfa-dozen ór more rods off.

Thoreau: Winter.

1 The slate-colored junco or snowbird, now called by scientists Junco hyemalis. - ED. 
FEBRUARY

29 


\section{MARCH}

I

I go listening, but in vain, for the warble of the bluebird from the old orchard across the river. I love to look now at the fine-grained russet hillsides in the sun, ready to relieve and contrast with the azure of the bluebirds. . . Heard two hawks scream. There was something truly March-like in it, like a prolonged blast or whistling of the wind through a crevice in the sky, which, like a cracked blue saucer, overlaps the woods. Such are the first rude notes which prelude the summer's choir, learned of the whistling March wind.

Thoreau: Early Spring in Massachusetts.

\section{2}

The storm is over, and it is one of those beautiful winter mornings when a vapor is seen hanging in the air between the village and the woods.

THoREAU: Winter.

There are days when almost complete silence possesses the woods, yet listening intently one may hear the continual movement of myriads of snow fleas pattering on the fallen leaves like the soft purr of such showers as one might imagine would fall in Lilliput.

Robissos: In New England Fields and Woods. 


\section{MARCH}

I

2 


\section{MARCH}

In this clear air and bright sunlight, the ice-covered trees have a new beauty, especially the birches along under the edge of Warren's wood on each side of the railroad, bent quite to the ground in every kind of curve. At a distance, as you are approaching them endwise, they look like the white tents of Indians under the edge of the wood. The birch is thus remarkable, perhaps, from the feathery form of the tree, whose numerous small branches sustain so great weight, bending it to the ground; and, moreover, because, from the color of the bark, the core is less observable.

Thoreav: Winter.

\section{4}

Dry snow covered the ground. Along the stone walls it had drifted heavily, reaching in many places a depth of two feet. Walking in the ploughed fields was uncertain, the furrows being filled with snow and the ridges blown free from it. The brooks were noisy, but their music was muffled by decks of thin ice which partially covered them. Great white air bubbles rolled along under these ice decks. Here and there watercress, buttercup leaves and long blades of grass could be seen pressed upward against the transparent ice by the pulsating current. In one pool in the pine woods the floor of the little basin was studded with scarlet partridge berries, surrounded by their rich green leaves.

Bolles: Land of the Lingering Snow. 
MARCH

3 


\section{MARCH}

5

I noticed a few chickadees there in the edge of the pines in the sun, lisping and twittering cheerfully to one another with reference to me, I think, the cunning and innocent little birds. One a little farther off utters the phobe note. There is a foot, more or less, of clear, open water at the edge here, and seeing this, one of these birds hops down, as if glad to find any open water at this season, and after prinking, it stands in the water on a stone, up to its belly, and dips its head, and flirts the water about vigorously, giving itself a good washing. I had not expected this at this season. No fear that it will catch cold.

Thoreav: Winter.

\section{6}

The sun, when he sets about destroying the ice, does not simply melt it from the surface, - that were a slow process; but he sends his shafts into it and separates it into spikes and needles, - in short, makes kindling-wood of it, so as to consume it the quicker.

Burrovghs: Signs and Seasons.

A soft rain began to fall, and it loosed the tongues of the birds. Chickadees called from tree to hedge. Golden-crested kinglets lisped to each other in the cedars. A dozen crows circled over the high pines, cawing discontentedly.

Bolles: Land of the Lingering Snow. 
MARCH

5 


\section{$\mathrm{MARCH}$}

\section{7}

See two yellow-spotted tortoises in the ditch S. of Trillium wood. You saunter expectant in the mild air along the soft edge of a ditch filled in with melted snow, and paved with leaves in some sheltered place, yet perhaps with some ice at one end still, and are thrilled to see stirring mid the leaves at the bottom, sluggishly burying themselves from your sight again, these brilliantly spotted creatures. There are commonly two, at least. The tortoise is stirring in the ditches again. In your"latest spring, they still look incredibly strange when first seen, and not like cohabitants and contemporaries of yours.

Thoreau: Winter.

\section{8}

The birds in the stubble field proved to be treesparrows. They were feeding on the seeds of weeds found on patches of moist earth left bare by the wasting snow. Each bird was saying something in a joyous recitative which he maintained continuously, regardless of the rippling mirth of his companions. I crept close to them and watched them through the embrasures of an old stone wall. Their chestnut caps, white wing-bars and long slender tails make them easy birds to recognize. As I rose they flew, nearly thirty strong, and vanished in the mist.

Bolles: Land of the Lingering Snow. 
MARCH

7

8 


\section{MARCH}

9

The other evening, as I stood on the slope of a hill in the twilight, I heard a whistling of approaching wings, and presently a woodcock flying low passed near me. I could see his form and his long curved wings dimly against the horizon; his whistling slowly vanished in the gathering night, but his passage made something stir and respond within me. March was on the wing, she was abroad in the soft still twilight searching out the moist, springy places where the worms first come to the surface and where the grass first starts; and her course was up the valley from the south.

Burroughs: Riverby.

10

I go along the river-side to see the now novel reflections. The invading waters have left a thousand little isles where willows and sweet gale and the meadow itself appears. I hear the phobe note of the chickadee, one taking it up behind another, as in a catch, phe-bee phe-bee.

Thoreau: Early Spring in Massachusetts.

Just after sundown I see a large flock of wild geese in a perfect harrow cleaving their way toward the northeast, with Napoleonic tactics splitting the forces of winter.

Thoreau: Early Spring in Massachusetts. 
MARCH

9

IO

Bluebird. 


\section{MARCH}

\section{I}

The ice in the pond at length begins to be honeycombed, and I can set my heel in it as I walk. Fogs and rains and warmer suns are gradually melting the snow; the days have grown sensibly longer; and I see how I shall get through the winter without adding to my woodpile, for large fires are no longer necessary. I am on the alert for the first signs of spring, to hear the chance note of some arriving bird, or the striped squirrel's chirp, for his stores must be now nearly exhausted, or see the woodchuck venture out of his winter quarters.

Thoreau: Walden.

\section{2}

As it grew darker, I was startled by the honking of geese flying low over the woods, like weary travelers getting in late from southern lakes, and indulging at last in unrestrained complaint and mutual consolation. Standing at my door, I could hear the rush of their wings; when, driving toward my house, they suddenly spied my light, and with hushed clamor wheeled and settled in the pond. So I came in, and shut the door, and passed my first spring night in the woods.

Thoreau: Walden. 


\section{$\mathrm{MARCH}$}

I I

I 2

Song Sparrow. 


\section{MARCH}

The water on the meadow this still bright morning is smooth as in April. I am surprised to hear the strain of a song sparrow from the river-side, and as I cross from the causeway to the hill, thinking of the bluebird, I that instant hear one's note from deep in the softened air. It is already $40^{\circ}$. By noon it is between $50^{\circ}$ and $60^{\circ}$. As the day advances I hear more bluebirds, and see their azure flakes settling on the fenceposts. Their short rich warble curls through the air. Its grain now lies parallel to the bluebird's warble, like boards of the same lot.

Thoreau: Early Spring in Massachusetts.

\section{I4}

Above, the hen-hawk swims and swoops,

Flung from the bright, blue sky;

Below, the robin hops, and whoops

His piercing Indian cry.

Holmes: After a Lecture on Wordsworth.

The sun and the south wind, which perhaps bears some faint breath of stolen fragrance from far-off violet banks, tempt forth the bees, but they find no flowers yet, not even a squirrelcup or willow catkin, and can only make the most of the fresh sawdust by the wood-pile and the sappy ends of maple logs.

Robixsox: In New England Fields and Woods. 


\section{MARCH}

13

14

Robin. 


\section{MARCH}

15

And yonder bluebird with the earth tinge on his breast and the sky tinge on his back, - did he come down out of heaven on that bright March morning when he told us so softly and plaintively that, if we pleased, spring had come? Indeed, there is nothing in the return of the birds more curious and suggestive than in the first appearance, or rumors of the appearance, of this little blue-coat. The bird at first seems a mere wandering voice in the air: one hears its call or carol on some bright March morning, but is uncertain of its source or direction.

Burroughs: Wake-Robin.

\section{I6}

At Hubbard's wall how handsome the willow catkins I Those wonderfully bright silvery buttons so regularly disposed in oval schools in the air, or, if you please, along the seams which the twigs make, in all degrees of forwardness, from the faintest, tiniest speck of silver just peeping from beneath the black scales to lusty pussies which have thrown off their scaly coats, and show some redness at base or on close inspection. These fixed swarms of arctic buds spot the air very prettily along the hedges. They remind me somewhat by their brilliancy of the snowflakes, which are so bright by contrast at this season when the sun is high.

Thoreau: Early Spring in Massachusetts. 


\section{$\mathrm{MARCH}$}

I 5

The Glaucous Willow begins to show its white "pussies." 


\section{MARCH}

\section{7}

A day or two later I sat on a hillside in the woods late in the day amid the pines and hemlocks, and heard the soft, elusive spring call of the little owl - a curious musical undertone hardly separable from the silence ; a bell, muffled in feathers, tolling in the twilight of the woods and discernible only to the most alert ear. But it was the voice of spring, the voice of the same impulse that sent the woodcock winging his way through the dusk, that was just beginning to make the pussy-willows swell and the grass to freshen in the spring runs.

Burrovghs: Riverby.

\section{8}

I hear the song sparrow practicing his first matins for the year. No wonder his song has been compared to the tinkling of bells! A more vibrating, resonant quality there is not in the whole choir of native-bird voices. His ditty consists of three short introductory notes (embodying the theme or motive, perhaps) ; these three notes translating themselves, to my ear, in the syllables "sweet, sweet, sweet," with a drawing in of the breath each time, followed by a bewildering succession of delicious tintinnabulations.

Eрiтн M. Thомas: The Round Year. 


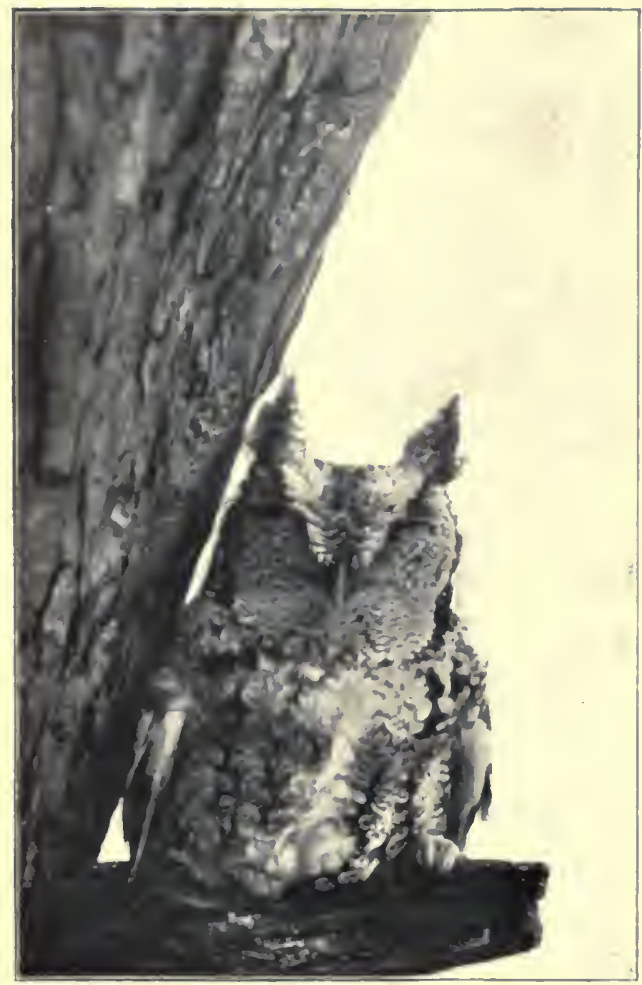



MARCH

I7

I8 


\section{MARCH}

\section{9}

At the Hubbard Path a mink comes tetering along the ice by the side of the river.... He seems daintily lifting his feet with a jerk as if his toes were sore. They seem to go a-hunting at night along the edge of the river. Perhaps I notice them more at this season, when the shallow water freezes at night, and there is no vegetation along the shore to conceal them.

Thoreau: Early Spring in Massachusetts.

In two or three places I hear the ground-squirrel's first chirrup or qui vive in the wall, like a bird or a cricket.

Thoreav: Early Spring in Massachusetts.

\section{0}

I saw a whole flock of daring blackbirds careering above the gusty woods in the March gale. They seemed to be exercising their speed and agility in one of the heroic games of the air. When they reached a goal, or station in the top of some high tree, they disposed themselves about the branches like so many weather-vanes, all facing in the same direction, and all indicating the south-southwest. This was practically "trimming to the wind."

Eрiтн M. Thomas: The Round Year.

Almost every bush has its song sparrow this morning, and their tinkling strains are heard on all sides.

Thoreau: Early Spring in Massachusetts. 


\section{$\mathrm{MARCH}$}

19

Red-winged Blackbird; Fox Sparrow. 


\section{MARCH}

\section{I}

$\mathrm{Ah}$, there is the note of the first flicker, - a prolonged, monotonous wick-wick-wick-wick-wick-wick, etc., or, if you please, quick-quick-quick, heard far over and through the dry leaves. But how that single sound peoples and enriches all the woods and fields! They are no longer the same woods and fields that they were. This note really quickens what was dead. It seems to put life into the withered grass and leaves and bare twigs, and henceforth the days shall not be as they have been. Thoreau: Early Spring in Massachusetts.

\section{2}

Why chidest thou the tardy Spring?

The hardy bunting does not chide; The blackbirds make the maples ring

With social cheer and jubilee;

The redwing futes his o-ka-lee,

The robins know the melting snow.

Emerson: May-Day.

If you scan the horizon at this season you are very likely to detect a flock of dark ducks moving with rapid wing athwart the sky, or see the undulating line of migrating geese.

Thoreau: Early Spring in Massachusetts. 


\section{MARCH}

2 I

Rusty Blackbird.

22 


\section{MARCH}

23

Round to the white bridge, where the red-maple buds are already much expanded, foretelling summer, though our eyes see only winter as yet. As I sit under their boughs looking into the sky, I suddenly see the myriad black dots of the expanded buds against the sky. Their sap is flowing. The elm buds, too, I find are expanded, though on earth are no signs of spring.

Thoreav: Early Spring in Massachusetts.

I hear the pleasant phœbe note of the chickadee. It is, methinks, more like a wilderness note than any other I have heard yet.

Thoreav: Early Spring in Massachusetts.

\section{4}

I hear the bluebird, the song sparrow, and the robin, and the note of the lark leaks up through the meadows, as if its bill had been thawed by the warm sun.

Thoread: Early Spring in Massachusetts.

The woodchuck and the chipmunk have got on top of the world again. You hear the half querulous, half chuckling whistle of the one, the fullmouthed persistent cluck of the other, voicing recognition of the season.

Robissox: In New England Fields and Woods. 


\section{$\mathrm{MARCH}$}

23

24

Meadowlark. 


\section{MARCH}

\section{5}

The tree sparrow is perhaps the sweetest and most melodious warbler at present and for some days. It is peculiar, too, for singing in concert along the hedge-rows, much like a canary, especially in the mornings, very clear, sweet, melodious notes, between a twitter and a warble, of which it is hard to catch the strain, for you commonly hear many at once.

Thoreav: Early Spring in Massachusetts.

The bluebird's warble comes feeble and frozen to my ear.

Thoreau: Early Spring in Massachusetts.

\section{6}

The ducks alight at this season in the still water, in company with the gulls, which do not fail to improve an east wind to visit our meadows, and swim about by twos and threes, pluming themselves, and diving to peck at the root of the lily, and the cranberries which the frost has not loosened. The first flock of geese is seen beating to north, in long harrows and waving lines; the jingle of the song sparrow salutes us from the shrubs and fences; the plaintive note of the lark comes clear and sweet from the meadow; and the bluebird, like an azure ray, glances past us in our walk.

THoreav: Natural History of Massachusetts. 


\section{MARCH}

25

Skunk Cabbage.

26 


\section{MARCH}

\section{7}

I see a woodchuck out on the calm side of Lee's Hill (Nawshawtuck). He has pushed away the withered leaves which filled his hole, and come forth, and left his tracks on those slight patches of the recent snow which are left about his hole.

Thoreau: Early Spring in Massachusetts.

The marsh hawk sailing low over the meadow is already seeking the first slimy life that awakes. The sinking sound of melting snow is heard in all dells, and the ice dissolves apace in the ponds.

Thoreav: Walden.

\section{8}

Occasionally, of a bright, warm, still day in March, such as we have had the present season, the little flying spider is abroad. It is the most delicate of all March tokens, but very suggestive. Its long, waving threads of gossamer, invisible except when the sunlight falls upon them at a particular angle, stream out here and there upon the air, a filament of life, reaching and reaching as if to catch and detain the most subtle of the skyey influences.

Burrovghs: Riverby. 
MARCH

27

28 


\section{MARCH}

\section{9}

Princes and magistrates are often styled serene, but what is their turbid serenity to that ethereal serenity which the bluebird embodies. His most serene Birdship! His soft warble melts in the ear as the snow is melting in the valleys around. The bluebird comes, and with his warble drills the ice, and sets free the rivers and ponds and frozen ground. As the sand flows down the slopes a little way, assuming the forms of foliage when the frost comes out of the ground, so this little rill of melody flows a short way down the concave of the sky.

Thoread: Early Spring in Massachusetts.

\section{0}

March water is usually clean, sweet water; every brook is a trout-brook, a mountain brook; the cold and the snow have supplied the condition of a high latitude; no stagnation, no corruption, comes downstream now as on a summer freshet. Winter comes down, liquid and repentant. Indeed, it is more than water that runs then : it is frost subdued ; it is spring triumphant. No obsolete watercourses now. The larger creeks seek out their abandoned beds, return to the haunts of their youth, and linger fondly there. The muskrat is adrift, but not homeless; his range is vastly extended, and he evidently rejoices in full streams.

Burrovghs: Signs and Seasons. 


\section{$\mathrm{MARCH}$}

29

30

Phøbe. 


\section{MARCH}

\section{$3 \mathbf{I}$}

The little brown brooks, - how swift and full they ran! One fancied something gleeful and hilarious in them. And the large creeks, - how steadily they rolled on, trailing their ample skirts along the edges of the fields and marshes, and leaving ragged patches of water here and there! Many a gentle slope spread, as it were, a turfy apron in which reposed a little pool or lakelet. Many a stream sent little detachments across lots, the sparkling water seeming to trip lightly over the unbroken turf. Here and there an oak or an elm stood knee-deep in a clear pool, as if rising from its bath. It gives one a fresh, genial feeling to see such a bountiful supply of pure, running water. One's desires and affinities go out toward the full streams. How many a parched place they reach and lap in one's memory! How many a vision of naked pebbles and sun-baked banks they cover and blot out!

Burrovghs: Signs and Seasons. 


\section{$\mathrm{MARCH}$}

3 I

Cowbird. 


\section{APRIL}

Saw a pigeon woodpecker flash away, showing the rich golden underside of its glancing wings and the large whitish spot on its back, and presently I heard its familiar, long-repeated, loud note, almost as familiar as that of a barn-door fowl, which it somewhat resembles. The robins, too, now toward sunset, perched on the old apple-trees in Tarbel's orchard, twirl forth their evening lays unweariedly. . . . To-night, for the first time, I hear the hylas in full blast.

Thoreav: Early Spring in Massachusetts.

How still the morning is 1 It is at such times that we discover what music there is in the souls of the little slate-colored snowbirds. How they squeal, and chatter, and chirp, and trill, always in scattered troops of fifty or a hundred, filling the air with a fine sibilant chorus I That joyous and childlike "chew," "chew," "chew" is very expressive. Through this medley of finer songs and calls, there is shot, from time to time, the clear, strong note of the meadowlark. It comes from some field or tree farther away, and cleaves the air like an arrow.

Burroughs: Pepacton. 
APRIL

I

Hylas (H. pickeringii) begin peeping.

2 


\section{APRIL}

3

John Burroughs, 1837.

Was it a squirrel's pettish bark,

Or clarionet of jay? or hark

Where yon wedged line the Nestor leads,

Steering north with raucous cry

Through tracts and provinces of sky,

Every night alighting down

In new landscapes of romance,

Where darkling feed the clamorous clans

By lonely lakes to men unknown.

Emerson: May-Day.

\section{4}

Going down town this morning, I am surprised by the rich strain of the purple finch from the elms. Three or four have arrived and lodged against the elms of our street, which runs east and west across their course, and they are now mingling their loud, rich strain with that of the tree sparrows, robins, bluebirds, etc. The hearing of this note implies some improvement in the acoustics of the air. It reminds me of that genial state of the air when the elms are in bloom. They sit still over the street, and make a business of warbling. They advertise one, surely, of some additional warmth and serenity.

THoreav: Early Spring in Massachusetts. 


\section{APRIL}

3

4

Purple Finch. 


\section{APRIL}

\section{5}

Now when the leaves get to be dry and rustle under your feet, the peculiar dry note, wurrk wurrk wur $r$ r wurk, of the wood-frog is heard faintly by ears on the alert, borne up from some unseen pool in a woodland hollow which is open to the influences of the sun. It is a singular sound for awakening nature to make, associated with the first warmer days when you sit in some sheltered place in the woods amid the dried leaves.

Thoreav: Early Spring in Massachusetts.

\section{6}

First notice the ring of the toad as I am crossing the common in front of the meeting-house. There is a cool and breezy south wind, and the ring of the first toad leaks into the general stream of sound unnoticed by most, as the mill brook empties into the river, and the voyager cannot tell if he is above or below its mouth. . . . It is a sound from amid the waves of the aerial sea, that breaks on our ears with the surf of the air, - a sound that is almost breathed with the wind, taken into the lungs instead of being heard by the ears. It comes from far over and through the troughs of the aerial sea, like a petrel; and who can guess by what pool the singer sits?

Thoreav: May Days 


\section{APRIL}

\section{5}

Wood-frogs begin clucking.

6

Common toads begin their spring trill. 


\section{APRIL}

\section{7}

A large company of fox-colored sparrows in Heywood's maple swamp close by. I heard their loud, sweet, canary-like whistle thirty or forty rods off, sounding richer than anything else yet; some on the bushes, singing twee twee twa twa twa ter tweer tweer twa. This is the scheme of it only, there being no dental grit. They were shy, flitting before me, and I heard a slight susurrus where many were busily scratching amid the leaves in the swamp, without seeing them, and also saw many indistinctly.

Troneav: Early Spring in Massachusetts.

\section{8}

All along on the south side of this hill, on the edge of the meadow, the air resounds with the hum of honey-bees, attracted by the flower of the skunk-cabbage. I first heard the fine, peculiarly sharp hum of the honey-bee before I thought of them. Some hummed hollowly within the spathe, perchance to give notice to their fellows that the plant was occupied, for they repeatedly looked in and backed out on finding another. ... Some of these spathes are now quite large and twisted up like cows' horns, not curved over, as usual. Commonly they make a pretty little crypt or shrine for the flower. Lucky that this flower does not flavor their honey.

ThOREAv: Early Spring in Massachusetts. 


\section{APRIL}

\section{7}

Tree Swallow.

American Elm.

8

Vesper Sparrow. 


\section{APRIL}

9

The robin is the singer at present, such is its power and universality, being heard both in garden and wood. Morning and evening he does not fail, perched on some elm or the like, and in rainy days it is one long morning or evening. The song sparrow is still more universal, but not so powerful. The lark, too, is equally constant morning and evening, but confined to certain localities, as is the blackbird to some extent. The bluebird with feebler, but not less sweet warbling, helps fill the air, and the phœbe does her part.

Thoreau: Early Spring in Massachusetts.

\section{0}

The fish hawk, too, is occasionally seen at this season sailing majestically over the water, and he who has once observed it will not soon forget the majesty of its flight. It sails the air like a ship of the line, worthy to struggle with the elements, falling back from time to time like a ship on its beam ends, and holding its talons up as if ready for the arrows, in the attitude of the national bird. It is a great presence, as of the master of river and forest. Its eye would not quail before the owner of the soil, but make him feel like an intruder on its domains. And then its retreat, sailing so steadily away, is a kind of advance.

THOREAU: Natural History of Massachusetts. 
APRIL

9

IO

Red Maple. 


\section{APRIL}

\section{I}

The woods ring with the cheerful jingle of the Fringilla hiemalis [the slate-colored junco or snowbird, now called by ornithologists Junco hyemalis. - ED.]. This is a very trig and compact little bird, and appears to be in good condition. The straight edge of slate on their breasts contrasts remarkably with the white from beneath. The short, light-colored bill is also very conspicuous amid the dark slate, and when they fly from you, the two white feathers in their tails are very distinct at a good distance. They are very lively, pursuing each other from bush to bush.

THOREAU: Early Spring in Massachusetts.

At Hayden's I hear hylas on two keys or notes. Heard one after the other; the sounds might be mistaken for the varied note of one. The little croakers, too, are very lively there. I get close to them, and witness a great commotion, they half hopping and half swimming about with their heads out, apparently in pursuit of each other, perhaps thirty or forty within a few square yards, and fifteen or twenty within one yard. ... As I approach nearer, they disperse and bury themselves in the grass at the bottom, only one or two remaining outstretched upon the surface; and at another step, these, too, conceal themselves.

Thoreav: Early Spring in Massachusetts. 
APRIL

I I

12

Pine Warbler. 


\section{APRIL}

I 3

That long, clear, cool note, like the arc described by a bright new sickle, — that's the meadowlark! I know well the springy pasture where he hunts his breakfast, the wind-crisped pools where he sornetimes dips his bill.

Editu M. Thомas: The Round Year.

In my walks in April, I am on the lookout for watercresses. It is a plant that has the pungent April flavor. In many parts of the country the watercress seems to have become completely naturalized, and is essentially a wild plant.

Burrovghs: Signs and Seasons.

\section{I4}

The painted wood drake swims above the submerged tree roots; a pair of dusky ducks splash to flight, with a raucous clamor, out of a sedgy cove at your approach ; the thronging blackbirds shower liquid melody and hail of discord from the purplebudded maples above you. All around, from the drift of floating and stranded water weeds, arises the dry, crackling croak of frogs, and from sunny pools the vibrant trill of toads.

Robixsox: In New England Fields and Woods. 


\section{APRIL}

I 3

Swamp Sparrow.

14

Ruby-crowned Kinglet. 


\section{APRIL}

\section{5}

But who ever dreamed of calling the chipping sparrow a fine singer? And yet, who that knows it does not love his earnest, long-drawn trill, dry and tuneless as it is? I can speak for one, at all events; and he always has an ear open for it by the middle of April. It is the voice of a friend, a friend so true and gentle and confiding that we do not care to ask whether his voice be smooth and his speech eloquent.

TORREY: Birds in the Bush.

\section{6}

There are many things left for May, but nothing fairer, if as fair, as the first flower, the hepatica. I find I have never admired this little firstling half enough. When at the maturity of its charms, it is certainly the gem of the woods. What an individuality it has I No two clusters alike; all shades and sizes; some are snow-white, some pale pink, with just a tinge of violet, some deep purple, others the purest blue, others blue touched with lilac. A solitary blue-purple one, fully expanded and rising over the brown leaves or the green moss, its cluster of minute anthers showing like a group of pale stars on its little firmament, is enough to arrest and hold the dullest eye.

Burroughs: Signs and Seasons. 


\section{APRIL}

\section{5}

Chipping Sparrow ; Field Sparrow.

Trailing Arbutus.

Yellow Palm Warbler.

Hepatica. 


\section{APRIL}

\section{7}

As I go down the street just after sunset, I hear many snipe to-night. At this hour, that is, in the twilight, they make a hovering sound high in the air over the villages, and the inhabitants do not know what to refer it to. It is very easily imitated by a sort of shuddering with the breath.... Perhaps no one dreamed of snipe an hour ago, and the air seemed empty of such as they; but as soon as the dusk begins, so that a bird's flight is concealed, you hear this peculiar, spirit-suggesting sound, now far, now near, heard through and above the evening din of the village.

Thoreav: Early Spring in Massachusetts.

\section{8}

I hear a robin singing in the woods south of Hosmer's, just before sunset. It is a sound associated with New England village life. It brings to my thoughts summer evenings when the children are playing in the yards before the doors, and their parents, conversing, sit at the open windows. It foretells all this now, before those summer hours are come.

As I come over the turnpike, the song sparrow's jingle comes up from every part of the meadow, as native as the tinkling rills or the blossoms of the spiræa. Its cheep is like the sound of opening buds. Thoreau: Early Spring in Massachusetts. 
APRIL

I 7

Hermit Thrush.

I 8 


\section{APRIL}

\section{9}

After crossing the arrow-head fields, we see a woodchuck run along and climb to the top of a wall and sit erect there, - our first. It is almost exactly the color of the ground, the wall, and the bare brown twigs altogether. When in the Miles swamp field we see two, one chasing the other, coming very fast down the lilac-field hill, straight toward us, while we squat still in the middle of the field. The foremost is a small gray or slaty-colored one; the other, two or three times as heary, and a warm tawny, decidedly yellowish in the sun, a very large and fat one, pursuing the first.

Thoreav: May Days.

\section{0}

By the river I see distinctly redwings and hear their conqueree. They are not associated with grackles. They are an age before their cousins, have attained to clearness and liquidity, they are officers, epauletted. The others are rank and file. I distinguish one even by its flight, hovering slowly from treetop to treetop, as if ready to utter its liquid notes. Their whistle is very clear and sharp, while that of the grackle is ragged and split.

Thoredu: Early Spring in Massachusetts. 


\section{APRIL}

19

Savanna Sparrow.

20

Dandelion. 


\section{APRIL}

\section{1}

High in the air white-bellied swallows reveled in the sunlight. The sweet-breathed west wind bore to us the kindred songs of the purple finch and the vesper sparrow, the plaint of the meadowlark, the drumming of the downy woodpecker, and the cawing of the crow. In a pine grove near by, the pine-creeping warbler and the chipping sparrow contrasted their monotonous repetitions of a single note, the one giving a smooth, well-rounded trill, the other a sharper, more pointed one.

Bolles: Land of the Lingering Snow.

\section{2}

Wilson says that the only note of the rusty grackle is a cluck, though he is told that at Hudson's Bay at the breeding time they sing with a fine note. Here they utter not only a cluck, but a fine shrill whistle. They cover the top of a tree now, and their concert is of this character. They all seem laboring together to get out a clear strain, as it were wetting their whistles against their arrival at Hudson's Bay. They begin, as it were, by disgorging or spitting it out like so much tow, from a full throat, and conclude with a clear, fine, shrill, ear-piercing whistle.

Thoreau: Early Spring in Massachusetts. 


\section{APRIL}

2 I

Plantain-leaved Everlasting.

22

Houstonia (H. cerulea). 


\section{APRIL}

\section{3}

The grass is greening here and there on the moist slopes and by the spring runs; the first furrow has been struck by the farmer; the liver-leaf is in the height of its beauty, and the bright constellations of the bloodroot shine out here and there; one has had his first taste and his second taste of the spring and of the woods, and his tongue is sharpened rather than cloyed. Now he will take the most delicious and satisfying draught of all, the very essence and soul of the early season, of the tender brooding days, with all their prophecies and awakenings, in the handful of trailing arbutus which he gathers in his walk.

Burrovghs: Riverby.

\section{4}

See a little blue butterfly fluttering about on the dry brown leaves in a warm place by the swamp side, making a pleasant contrast. From time to time have seen the large Vanessa antiopa resting on the black willows, like a leaf still adhering. As I sit by the swamp side this warm summery afternoon I hear the crows cawing hoarsely, and from time to time see one flying toward the top of a tall white pine. At length I distinguish a hen-hawk perched on the top. The crow repeatedly stoops toward him, now from this side, now from that, passing near his head each time, but he pays not the least attention to it.

Thoreau: May Days. 
APRIL

23

Marsh Marigold.

24

Myrtle Warbler. 


\section{APRIL}

$$
2 \dot{5}
$$

I wandered lonely where the pine-trees made Against the bitter East their barricade,

And, guided by its sweet

Perfume, I found, within a narrow dell,

The trailing spring flower tinted like a shell

Amid dry leaves and mosses at my feet.

Whittikr: The Trailing Arbutus.

The gray branches of the oaks, which have lost still more of their leaves, seen against the pines when the sun is rising and falling on them, how rich and interesting! Hear the faint, swelling, far-off beat of a partridge.

Thoreav: Early Spring in Massachusetts.

\section{6}

See the old barn on the meadow slope; the green seems to have oozed out from it, and to have flowed slowly down the hill; at a little distance it is lost in the sere stubble. One can see where every spring lies buried about the fields; its influence is felt at the surface, and the turf is early quickened there. Where the cattle have loved to lie and ruminate in the warm summer twilight, there the April sunshine loves to linger too, till the sod thrills to new life.

Burrougus: Signs and Seasons. 


\section{APRIL}

\section{5}

Solitary Vireo.

Wood Anemone; Bloodroot.

Purple Martin; Barn Swallow; Black and White Warbler. Common Cinquefoil. 


\section{APRIL}

\section{7}

Dear common flower, that grow'st beside the way, Fringing the dusty road with harmless gold,

First pledge of blithesome May, Which children pluck, and, full of pride uphold,

High-hearted buccaneers, o'erjoyed that they An Eldorado in the grass have found,

Which not the rich earth's ample round May match in wealth, thou art more dear to me Than all the prouder summer-blooms may be.

Lowell: To the Dandelion.

\section{8}

There is a brief period in our spring when I like more than at any other time to drive along the country roads, or even to be shot along by steam and have the landscape presented to me like a map. It is at that period, usually late in April, when we behold the first quickening of the earth. The waters have subsided, the roads have become dry, the sunshine has grown strong and its warmth has penetrated the sod; there is a stir of preparation about the farm and all through the country. One does not care to see things very closely; his interest in nature is not special but general. The earth is coming to life again.

Burrovghs: Signs and Seasons. 


\section{APRIL}

White-throated Sparrow; Towhee. Arrow-leaved Violet.

28

Brown Thrasher.

Early Saxifrage; Dog-tooth Violet. 


\section{APRIL}

29

It is only for a brief period that the blossoms of our sugar maple are sweet-scented; the perfume seems to become stale after a few days : but pass under this tree just at the right moment, say at nightfall on the first or second day of its perfect inflorescence, and the air is loaded with its sweetness; its perfumed breath falls upon you as its cool shadow does a few weeks later.

Burroughis: Pepacton.

The chipping sparrow, with its ashy white breast, white streak over eye, and undivided chestnut crown, holds up its head and pours forth its che che che che che che.

THOREAU : Early Spring in Massachusetts.

\section{0}

A few days earlier, grays, browns, and delicate yellows had prevailed. These were forgotten, swept away by a flood of green and crimson. The green of the meadows, roadsides, and upland hayfields was so vivid that all underlying tints were obliterated. The willows, which for weeks had been the most conspicuous color-spots in every view, had developed leaves strong enough in color to cancel the golden and coppery tones of their stems and merge them in the greens of grassland and meadow. The maples from gray and mist-like softness had with their red blossoms come forward as the most pronounced color-masses in the landscape.

Bolles : Land of the Lingering Snow. 


\section{APRIL}

29

Wild Strawberry (blooms).

30

Chimney Swift.

Common Blue Violet; Sweet White Violet. 


\section{MAY}

\section{I}

The chewink is a shy bird also, but not stealthy. It is very inquisitive, and sets up a great scratching among the leaves, apparently to attract your attention. The male is perhaps the most conspicuously marked of all the ground-birds except the bobolink, being black above, bay on the sides, and white beneath. The bay is in compliment to the leaves he is forever scratching among, - they have rustled against his breast and sides so long that these parts have taken their color; but whence come the white and black?

Burroughs : Birds and Poets.

Crossing the first Conantum field I perceive a peculiar fragrance in the air (not the meadow fragrance), like that of vernal flowers or of expanding buds. The ground is covered with the mouse-ear in full bloom, and it may be that in part. It is a temperate southwest breeze, and this is a scent of willows (flowers and leaflets), bluets, violets, shad-bush, mouse-ear, etc., combined, or perhaps the last chiefly. At any rate, it is very perceptible. The air is more genial, laden with the fragrance of spring flowers. I, sailing on the spring ocean, getting in from my winter voyage, begin to smell the land.

Thoreau : May Days. 


\section{MAY}

I

Rue Anemone.

2

Least Flycatcher.

Sugar Maple; Garden Cherry 
Again and again the sounds fell on my ear, and as often I endeavored to obtain a view of the singer; but he was in the thick of the upper branches, and I looked for him in vain. How delicious the music was! a perfect lullaby, drowsy and restful; like the benediction of the wood on the spirit of a tired city-dweller. I blessed the unknown songster in return; and even now I have a feeling that the peculiar enjoyment which the song of the black-throated green warbler never fails to afford me may perhaps be due in some measure to its association with that twilight hour.

Torrey: Birds in the Bush.

\section{4}

John James Audubon, 1780; Thomas Henry Huxley, 1825.

Near at hand, upon the topmost spray of a birch, sings the brown thrasher - or red mavis, as some love to call him - all the morning, glad of your society, that would find out another farmer's field if yours were not here. While you are planting the seed, he cries, - "Drop it, drop it, - cover it up, cover it up, - pull it up, pull it up, pull it up." . . . You may wonder what his rigmarole, his amateur Paganini performances on one string or on twenty, have to do with your planting, and yet prefer it to leached ashes or plaster.

Thoreau: Walden. 


\section{MAY}

3

Cliff Swallow; Bank Swallow; Black-throated Green Warbler.

Columbine; Bellwort (Uvularia sessifolia).

4

Yellow Warbler; House Wren 


\section{MAY}

\section{5}

Who has seen the partridge drum? It is the next thing to catching a weasel asleep, though by much caution and tact it may be done. He does not liug the log, but stands very erect, expands his ruff, gives two introductory blows, pauses half a second, and then resumes, striking faster and faster till the sound becomes a continuous, unbroken whir, the whole lasting less than half a minute. The tips of his wings barely brush the $\log$, so that the sound is produced rather by the force of the blows upon the air and upon his own body as in flying.

Burrovghs : Wake-Robin.

\section{6}

Coming to a drier and less mossy place in the woods, I am amused with the golden-crowned thrush, - which, however, is no thrush at all, but a warbler. He walks on the ground ahead of me with such an easy gliding motion, and with such an unconscious, preoccupied air, jerking his head like a hen or a partridge, now hurrying, now slackening his pace, that I pause to observe him. I sit down, he pauses to observe me, and extends his pretty ramblings on all sides, apparently very much engrossed with his own affairs, but never losing sight of me. But few of the birds are walkers, most being hoppers, like the robin.

Burroughs: Wake-Robin. 


\section{MAY}

\section{5}

Kingbird.

Shadbush.

6

Rose-breasted Grosbeak; Oven-bird. 
A peetweet and its mate. The river seems really inhabited when the peetweet is back. This bird does not return to our stream uutil the weather is decidedly pleasant and warm. He is perched on the accustomed rock. His note peoples the river like the prattle of children once more in the yard of a house that has stood empty. . . .

I am surprised by the tender yellowish green of the aspen leaves, just expauded suddenly, even like a fire, seen in the sun agaiust the dark brown twigs of the wood, though these leaflets are yet but thinly dispersed. It is very enlivening.

Thoreau: May Days.

\section{8}

'Nuff sed, June's bridesman, poet o' the year, Gladness on wings, the bobolink, is here; Half-hid in tip-top apple-blooms he swings, Or climbs aginst the breeze with quiveriu' wings, Or, givin' way to 't in a mock despair, Runs down, a brook o' laughter, thru the air. Lowell: The Biglow Papers.

The swallows dive and chatter about the barn, or squeak and build beneath the eaves; the partridge drums in the fresh sprouting woods; the long, tender note of the meadowlark comes up from the meadow; and at sunset, from every marsh and pond come the ten thousand voices of the hylas. Burrovgns: Wake-Robin. 


\section{MAY}

7

Warbling Vireo; Nashville Warbler; Chestnut-Sided Warbler ; Maryland Yellow-throat; Catbird.

Bobolink; Yellow-throated Vireo; Northern Parula Warbler; Redstart.

Bird-foot Violet. 


\section{MAY}

9

And hark! and hark! the woodland rings;

There thrilled the thrush's soul;

And look! that flash of flamy wings, -

The fire-plumed oriole!

HoLMEs: After a Lecture on Wordsworth.

The first whip-poor-will startles me; I hear three. Summer is coming apace. Within three or four days the birds have come so fast I can hardly keep the run of them, - much faster than the flowers.

\section{Thoreav: May Days.}

\section{IO}

Early in May, the oaks, hickories, maples, and other trees, just putting out amidst the pine woods around the pond, imparted a brightness like sunshine to the landscape, especially in cloudy days, as if the sun were breaking through the mists and shining faintly on the hillsides here and there.

THoreav: Walden.

Whist! There goes an oriole, a gorgeous creature, flashing from one elm to another, and piping in his happiest manner as he flies.

TorreY: The Foot-Path Way. 


\section{MAY}

9

Baltimore Oriole; Prairie Warbler.

Jack-in-the-Pulpit 


\section{MAX}

\section{I}

The wood thrush launches forth his evening strains from the midst of the pines. I admire the moderation of this master. There is nothing tumultuous in his song. He launches forth one strain of pure, unmatchable melody, and then he pauses and gives the hearer and himself time to digest this, and then another and another at suitable intervals. Men talk of the rich song of other birds, the thrasher, mockingbird, nightingale. But I doubt, I doubt. They know not what they say. There is as great an interval between the thrasher and the wood thrush as between Thomson's "Seasons" and Homer.

Thoreav: Summer.

\section{2}

One sometimes seems to discover a familiar wild flower anew.by coming upon it in some peculiar and striking situation. Our columbine is at all times and in all places one of the most exquisitely beautiful of flowers; yet one spring day, when I saw it growing out of a small seam on the face of a great lichen-covered wall of rock, where no soil or mould was visible, - a jet of foliage and color shooting out of a black line on the face of a perpendicular mountain wall and rising up like a tiny fountain, its drops turning to flame-colored jewels that hung and danced in the air against the gray rocky surface, - its beauty became something magical and audacious.

Burrotghs: Riverby. 


\section{MAY}

II

Whiteeyed Vireo; Wood Thrush; Wilson's Thrush.

12

Redeyed Vireo; Golden-winged Warbler; Black-throated Blue Warbler.

Downy Yellow Violet. 


\section{MAY}

\section{3}

I hear the song of the veery down there under the willows. It is a weird, ventriloquial song. The bird seems making its gypsy music to itself, not to the world. . . . The song of the veery has in it the tinkling of bells, the jangle of the tamborine. It recalls to me the gypsy chorus in the "Bohemian Girl," and when I hear it as evening draws on, I can picture light feet tripping over the damp grass, and in the shadows made by moving of branches and ferns I can see dark forms moving back and forth in the windings of the dance.

Bolles: Land of the Lingering Snow.

\section{I4}

Rowland Evans Robinson, 1833.

Thither too the woodcock led her brood, to probe the mud for worms, flying but a foot above them down the bank, while they ran in a troop beneath; but at last, spying me, she would leave her young and circle round and round me, nearer and nearer till within four or five feet, pretending broken wings and legs, to attract my attention, and get off her young, who would already have taken up their march, with faint wiry peep, single file through the swamp, as she directed. Or I heard the peep of the young when I could not see the parent bird.

ThoreaU: Walden. 


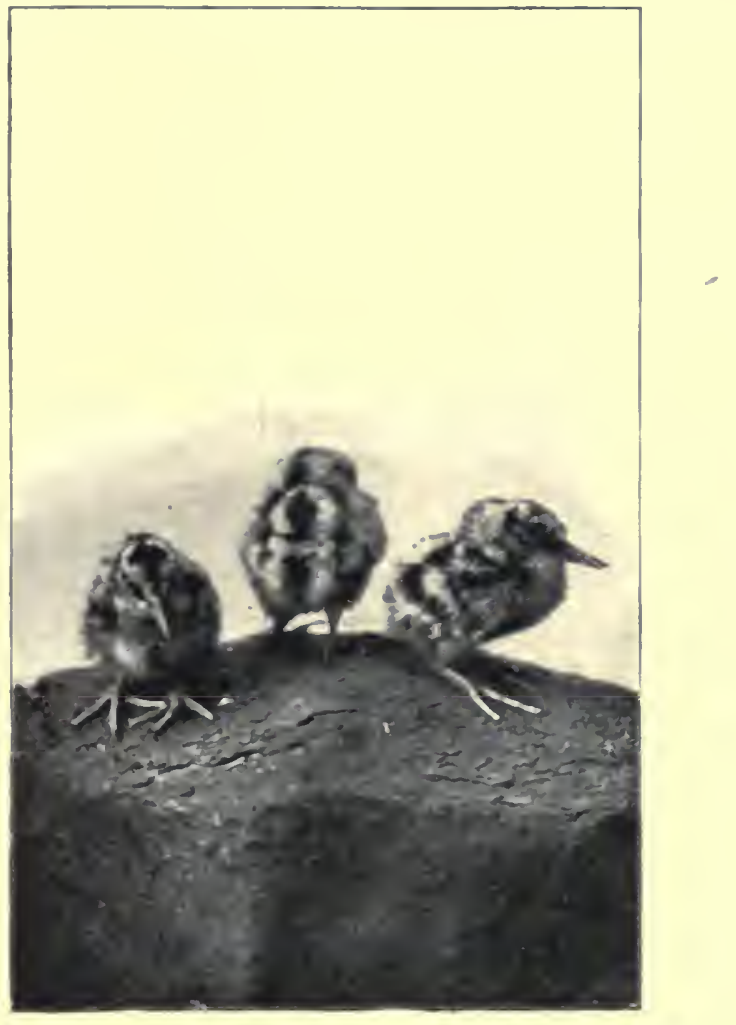





\section{MAY}

I 3

Scarlet Tanager.

Apple.

14

Magnolia IVarbler.

Bulbous Buttercup. 


\section{MAY}

\section{5}

The flowers of the apple are perhaps the most beautiful of any tree's, so copious and so delicious to both sight and scent. The walker is frequently tempted to turn and linger near some more than usually handsome one, whose blossoms are two thirds expanded. How superior it is in these respects to the pear, whose blossoms are neither colored nor fragrant!

Troreau: Wild Apples.

The feeble, sharp song of the black-poll is a singular affair ; short and slight as it is, it embraces a perfect crescendo and a perfect decrescendo.

Torrey: The Foot-Path Way.

\section{I6}

A female sparrow hawk darted from her nest in the deep hollow of an inaccessible limb, and flew with marvelous grace into the open, wheeled, and dropped upon the outstretched finger of one of the tallest trees of this tall grove. Her mate joined her and perched for a second beside her, while a queer whining chatter came from them. Their coloring is as beautiful as that of the fox sparrow, and if they cannot revive the fainting heart by song, they can give the eye joy by their speed, their perfect grace of flight, and the beauty of their outlines.

BotLLs: Land of the Lingering Snow. 


\section{MAY}

\section{5}

Yellow-billed Cuckoo; Ruby-throated Hummingbird; Blackpoll Warbler.

Male toads begin squawking.

Short-billed Marsh Wren; Long-billed Marsh Wren. Nodding Trillium. 


\section{MAX}

\section{7}

I know of nothing in vegetable nature that seems so really to be born as the ferns. They emerge from the ground rolled up, with a rudimentary and "touch-me-not" look, and appear to need a maternal tongue to lick them into shape. The sun plays the wet nurse to them, and very soon they are out of that uncanny covering in which they come swathed, and take their places with other green things.

Burrovgus: Signs and Seasons.

And, hark, the cuckoo weatherwise,

Still hiding farther onward, wooes you.

Lowell: The Nightingale in the Study.

\section{8}

Twice have the crow blackbirds attempted a settlement in my pines, and twice have the robins, who claim a right of preëmption, so successfully played the part of border-ruffians as to drive them away, - to my great regret, for they are the best substitute we have for rooks. At Shady Hill (now, alas! empty of its so long loved household) they build by hundreds, and nothing can be more cheery than their creaking clatter (like a convention of old-fashioned tavern-signs) as they gather at evening to debate in mass meeting their windy politics, or to gossip at their tent-doors over the events of the day.

Lowell: My Garden Acquaintance. 


\section{MAY}

17

Black-billed Cuckoo.

Rhodora.

Treetoads begin to trill.

18

Indigo Bunting. 


\section{MAY}

I9

I must not forget to mention that delicate and lovely flower of May, the fringed polygala. It is rather a shy flower, and is not found in every wood. One day we went up and down through the woods looking for it, - woods of mingled oak, chestnut, pine, and hemlock, - and were about giving it up when suddenly we came upon a gay company of them beside an old wood-road. It was as if a flock of small rose-purple butterflies had alighted there on the ground before us. The whole plant has a singularly fresh and tender aspect. Its foliage is of a slightly purple tinge, and of very delicate texture.

BUrRoughs: Riverby.

In May, when sea-winds pierced our solitudes, I found the fresh Rhodora in the woods, Spreading its leafless blooms in a damp nook, To please the desert and the sluggish brook. The purple petals, fallen in the pool, Made the black water'with their beauty gay; Here might the red-bird come his plumes to cool, And court the flower that cheapens his array. Rhodora! if the sages ask thee why This charm is wasted on the earth and sky, Tell them, dear, that if eyes were made for seeing, Then Beauty is its own excuse for being.

EMerson: The Rhodora. 


\section{MAY}

19

Wood Pewee.

Fringed Polygala; Purple Azalea.

Flowering Dogwood; Star-flower; Stemless Lady's-Slipper. 


\section{MAY}

I hear the note of a bobolink concealed in the top of an apple-tree behind me. . . He is just touching the strings of his theorbo, his glassichord, his water organ, and one or two notes globe themselves and fall in liquid bubbles from his tuning throat. It is as if he touched his harp within a vase of liquid melody, and when he lifted it out the notes fell like bubbles from the trembling strings. Methinks they are the most liquidly sweet and melodious sounds I ever heard.... Oh, never advance farther in your art; never let us hear your full strain, sir! But away he launches, and the meadow is all bespattered with melody.

ThoreaU: Summer.

22

Hear a red squirrel chirrup at me by the hemlocks.... He makes so many queer sounds, and so different from one another, that you would think they came from half a dozen creatures. I hear now two sounds from him of a very distinct character, a low or base internal, worming, screwing kind of sound (very like that, by the way, which an anxious partridge mother makes), and at the same time a very sharp and shrill bark, clear, and on a very high key, totally distinct from the last, while his tail is flourishing incessantly. You might say that he successfully accomplished the difficult feat of singing and whistling at the same time.

Thoreav: Early Spring in Massachusetts. 


\section{MAY}

2 I

Barberry ; Robin's Plantain; Dwarf Solomon's Seal.

Wild Cranesbill; Choke Cherry. 


\section{MAY}

23

LINNAUS, 1707.

The sumach (Rhus glabra) grew luxuriantly about the house, pushing up through the embankment which I had made, and growing five or six feet the first season. Its broad pinnate tropical leaf was pleasant though strange to look on. The large buds, suddenly pushing out late in the spring from dry sticks which had seemed to be dead, developed themselves as by magic into graceful green and tender boughs, an inch in diameter.

Thoreav: Walden.

\section{4}

Then, as it grew dark, it grew silent,-except for the hylas, - till suddenly a field sparrow gave out his sweet strain once. After that all was quiet for another interval, till a thrasher from the hillside began to sing. He ceased, and once more there was stillness. All at once the tanager broke forth in a strangely excited way, blurting out his phrase two or three times and subsiding as abruptly as he had commenced. Some crisis in his love-making, I imagined. Now the last oven-bird launched into the air and let fall a little shower of melody, and a whip-poor-will took up his chant afar off.

TorReY: Birds in the Bush. 
MAY

23

24 


\section{MAY}

\section{5}

Ralph Waldo Eyerson, 1803.

There were two hen-hawks that soared and circled for our entertainment when we were in the woods on this plain, crossing each other's orbits from time to time, alternating like the squirrels in their cylinder, till, alarmed by our imitation of a hawk's shrill cry, they gradually inflated themselves, made themselves more aerial, and rose higher and higher into the heavens, and were at length lost to sight; yet all the while earnestly looking, scanning the surface of the earth for a stray mouse or rabbit.

$$
\text { Thoreau: May Days. }
$$

\section{6}

The woods and fields next the Cliffs now ring with the silver jingle of the field sparrow, the medley of the brown thrasher, the honest qui vive of the chewink, or his jingle from the top of a low copse tree, while his mate scratches in the dry leaves beneath. The black and white creeper is hopping along the oak boughs, head downward, pausing from time to time to utter its note, like a fine, delicate saw sharpening, and ever and anon rises, clear over all, the smooth rich melody of the wood thrush.

$$
\text { Thoreau: May Days. }
$$

The note of the wood thrush answers to some cool, unexhausted morning vigor in the hearer.

Thoreav: Summer. 


\section{MAY}

25

Cow-lily; Golden Ragwort; Scarlet Painted-Cup; Blue-eyed Grass ; Star Grass.

Red Clover ; Daisy. 


\section{MAY}

\section{7}

I was amused with the behavior of two red squirrels, as I approached the hemlocks. . . . For four or five minutes at least they kept up an incessant chirruping or squeaking bark, vibrating their tails and their whole bodies, and frequently changing their position or point of view, making a show of rushing forward, or perhaps darting off a few feet like lightning, and barking still more loudly, $i$. e., with a yet sharper exclamation, as if frightened by their own motions, their whole bodies quivering, their heads and great eyes on the qui vive.

Thoreau: Early Spring in Massachusetts.

28

Louis Agassiz, 1807 .

Our Arethusa is one of the prettiest of the orchids, and has been pursued through many a marsh and quaking bog by her lovers. She is a bright pink-purple flower an inch or more long, with the odor of sweet violets. The sepals and petals rise up and arch over the column, which we may call the heart of the flower, as if shielding it.

Burroughs: Riverby.

As I come over the hill, I hear the wood thrush singing his evening lay. This is the only bird whose note affects me like music, affects the flow and tenor of my thought, my fancy, and imagina. tion. It lifts and exhilarates me.

ThoreaU: Summer. 


\section{MAY}

\section{7}

Pitcher-plant.

Bullfrogs begin to trumpet.

28

Arethusa. 


\section{MAY}

\section{9}

He is so harmless to man, that, were it not for the old, unreasoning antipathy, our hands would not be raised against him; and, if he were not a snake, we should call him beautiful in his stripes of black and gold, and in graceful motion - a motion that charms us in the undulation of waves, in their flickering reflections of sunlight on rushy margins and wooded shores, in the winding of a brook through a meadow, in the flutter of a pennant and the flaunting of a banner, the ripple of wind-swept meadow and grain field, and the sway of leafy boughs.

Robixsox: In New England Fields and Woods.

\section{0}

A serene evening, the sun going down behind clouds. A few white or slightly shaded piles of clouds floating in the eastern sky, but a broad, clear, mellow cope left for the moon to rise into. An evening for poets to describe. As I proceed along the back road I hear the lark still singing in the meadow, and the bobolink, the golden robin on the elms, and the swallows twittering about the barns. All Nature is in an expectant attitude.

THoreaU: Summer.

All that was ripest and fairest in the wilderness and the wild man is preserved and transmitted to us in the strain of the wood thrush.

Thoreav: Summer. 


\section{MAY}

29

Bunchberry; Water Arum. 


\section{MAY}

\section{I}

Within little more than a fortnight the woods, from bare twigs, have become a sea of verdure, and young shoots have contended with one another in the race. The leaves are unfurled all over the country. Shade is produced, the birds are concealed, their economies go forward uninterruptedly, and a covert is afforded to animals generally. But thousands of worms and insects are preying on the leaves while they are young and tender. Myriads of little parasols are suddenly spread all the country over to shield the earth and the roots of the trees from the parching heat, and they begin to flutter and to rustle in the breeze.

Thoreau: Summer. 
MAY

$3 I$ 


\section{JUNE}

I

The air has now begun to be filled with a bluish haze. These virgin shades of the year, when everything is tender, fresh, and green, how full of promise $!$ - promising bowers of shade in which heroes may repose themselves. I would fain be present at the birth of shadow. It takes place with the first expansion of the leaves.... The black willows are already beautiful, and the hemlocks with their bead-work of new green. Are these not kingbirddays, - these clearer first June days, full of light, when this aerial, twittering bird flutters from willow to willow, and swings on the twigs, showing his white-edged tail?

Thoreau: Summer.

The blue-eyed grass is one of the most beautiful of flowers. It might have been famous from Proserpine down. It will bear to be praised by poets.

Thoreav: Summer.

A few fireflies in the meadow. Do they shine, though invisibly, by day? Is their candle lighted by day? It is not nightfall till the whip-poor-wills begin to sing. . . . I heard a partridge drumming to-night as late as nine o'clock. What a singularly space-penetrating and filling sound! Why am I never nearer to its source?

Thoreau: Summer. 


\section{JUNE}

I

White Clover; Alsike Clover.

Tall Buttercup. 


\section{JUNE}

\section{3}

This morning I hear the note of young bluebirds in the air, which have recently taken wing, and the old birds keep up such a warbling and twittering as remind me of spring.

Thoreav: Summer.

The oven-bird's nest in Laurel Glen is near the edge of an open pine wood under a fallen pine twig and a heap of dry oak leaves. Within these on the ground is the nest, with a dome-like top and an arched entrance of the whole height and width on one side. Lined within with dry pine needles.

THoreav: Summer.

\section{4}

The delicate maiden-hair fern forms a cup or dish, very delicate and graceful. Beautiful, too, its glossy black stem and its wave-edged, fruited leaflets.

I hear the feeble, plaintive note of young bluebirds, just trying their wings or getting used to them. Young robins peep.

Thoreav: Summer.

I have stood under a tree in the woods half a day at a time, during a heavy rain in the summer, and yet employed myself happily and profitably there prying with microscopic eye into the crevices of the bark or the leaves of the fungi at my feet.

Thoreav: A Week on the Concord and Merrimack Rivers. 


\section{JUNE}

3

4

Blue Flag. 


\section{JUNE}

\section{5}

I am as white as a miller - a rye-miller, at least - with the lint from the young leaves and twigs. The tufts of pinks on the side of the peak by the pond grow raying out from a centre, somewhat like a cyme, on the warm, dry side hill, some a lighter, some a richer and darker shade of pink. With what a variety of colors we are entertained! Yet most colors are rare or in small doses, presented to us as a condiment or spice; much of green, blue, black, and white, but of yellow and the different shades of red, far less. The eyes feast on the colors of flowers as on tidbits.

Thoreav: Summer.

\section{6}

What delicate fans are the great red-oak leaves, now just developed, so thin, and of so tender $a$ green. They hang loosely, flaccidly down, at the mercy of the wind, like a new-born butterfly or dragon-fly. A strong, cold wind would blacken and tear them now. They remind me of the frailest stuffs hung around a dry-goods shop. They have not been hardened by exposure yet, these raw and tender lungs of the tree. The white-oak leaves are especially downy and lint your clothes.

This is truly June when you begin to see brakes (dark green) fully expanded in the wood paths.

Thoreav: Summer. 
JUNE

5

Wild Strawberries ripen.

6 


\section{JUNE}

\section{7}

A redwing's nest, four eggs, low in a tuft of sedge in an open meadow. What Champollion can translate the hieroglyphics on these eggs? It is always writing of the same character, though much diversified. While the bird picks up the material and lays this egg, who determines the style of the marking? When you approach, away dashes the dark mother, betraying her nest, and then chatters her anxiety from a neighboring bush, where she is soon joined by the red-shouldered male, who comes scolding over your head, chattering and uttering a sharp "phe phee-e."

Thoreav: Summer.

\section{8}

. . The painted cup is in its prime. It reddens the meadow, Painted Cup Meadow. It is a splendid show of brilliant scarlet, the color of the cardinal flower and surpassing it in mass and profusion. They first appear on the side of the hill, on dryer ground, half a dozen inches high, and the color is most striking then, when it is most rare and precious; but they now cover the meadow mingled with buttercups, etc., and many are more than eight inches high. I do not like the name. It does not remind me of a cup, rather of a flame when it first appears. It might be called flame flower, or scarlet tip.

Thoreav: Summer. 


\section{JUNE}

7

Sheep Laurel.

8 


\section{JUNE}

\section{9}

How full is the air of sound at sunset and just after !-especially at the end of a rain storm. Every bird seems to be singing in the wood across the stream, and there are the hylodes [peeping hylas - Ev.] and the sounds of the village. Beside, sounds are more distinctly heard. Ever and anon we hear a few sucks or strokes from the bittern or stake driver, whenever we lie to, as if he had taken the job of extending all the fences up the river, to keep the cows from straying. We hear but three or four toads in all, to-night, but as many hylodes as ever. It is too cool, both water and air (especially the first), after the rain, for the toads.

Thoreav: Summer.

\section{IO}

Instead of the white lily, which requires mud, or the sweet flag, here grows the blue flag in the water, thinly about the shore. The color of the flower harmonizes singularly with the water. With our boat's prow to the shore, we sat half an hour this evening, listening to the bull-frogs. What imperturbable fellows! One sits perfectly still behind some blades of grass while the dog is chasing others within two feet.... We see here and there light-colored, greenish, or white spots on the bottom, where a fish - a bream, perhaps - has picked away all the dead wood and leaves for her nest over a space of eighteen inches or more.

Thoreav: Summer. 


\section{JUNE}

9

10

Common Yarrow. 


\section{JUNE}

\section{I}

The pincushion galls on young white oaks are now among the most beautiful objects in the woods, - coarse, woolly, white, spotted with bright red or crimson on the exposed side. It is remarkable that a mere gall, which at first we are inclined to regard as something abnormal, should be made so beautiful, as if it were the flower of the tree; that a disease, an excrescence, should prove, perchance, the greatest beauty, as the tear of the pearl; beautiful scarlet sins they may be. Through our temptations, aye, and our falls, our virtues appear.

Thoreav: Summer.

\section{2}

The lupine is now in its glory. ... I am quite excited by this prospect of blue flowers in clumps, with narrow intervals, such a profusion of the heavenly, the Elysian color, as if these were the Elysian Fields. ... That is the value of the lupine. The earth is blued with it. Yet a third of a mile distant I do not detect their color on the hillside. Perchance because it is the color of the air. It is not distinct enough. You may have passed along here a fortnight ago, and the hillside was comparatively barren, but now you come, and these glorious redeemers appear to have flashed out here all at once.

Thoread: Summer. 
JUNE

I I

I2 


\section{JUNE}

\section{3}

The wild strawberry, like the wild apple, is spicy and high-flavored, but, unlike the apple, it is also mild and delicious. It has the true rustic sweetness and piquancy. What it lacks in size, when compared with the garden berry, it makes up in intensity. It is never dropsical or overgrown, but firm-fleshed and hardy. Its great enemies are the plow, gypsum, and the horserake. It dislikes a limestone soil, but seems to prefer the detritus of the stratified rock. Where the sugar maple abounds, I have always found plenty of wild strawberries.

Burroughs: Locusts and Wild Honey.

\section{I4}

The verdure, both of trees and grass, is now in its prime, the leaves elastic, all life. The grassfields are plenteously bestrewn with white-weed, large spaces looking as white as a sheet of snow, at a distance, yet with an indescribable warmer tinge than snow, - living white, intermixed with living green. The hills and hollows beyond the Cold Spring copiously shaded, principally with oaks of good growth, and some walnut-trees, with the rich sun brightening in the midst of the open spaces, and mellowing and fading into the shade, - and single trees, with their cool spot of shade, in the waste of sun : quite a picture of beauty, gently picturesque.

Hawthorve: American Note-Books. 


\section{JUNE}

13

14 


\section{JUNE}

\section{5}

The grass is waving, and, the trees having leaved out, their boughs feel the effect of the breeze. Thus new life and motion is imparted to the trees. The season of waving boughs, and the lighter under-sides of the new leaves are exposed. This is the first half of June. Already the grass is not so fresh and liquid velvety a green, having much of it blossomed, and some even gone to seed, and it is mixed with reduish ferns and other plants; but the general leafiness, shadiness, and waving of grass and boughs characterize the season. The wind is not quite agreeable, because it prevents your hearing the birds sing.

Thoreav: Summer.

$$
16
$$

The beauty and fragrance of the wild rose are wholly agreeable and wholesome, and wear well. I do not wonder much that men have given the preference to this family of flowers notwithstanding their thorns. It is hardy and more complete in its parts than most flowers, its color, buds, fragrance, leaves, the whole bush, frequently its stem in particular, and finally its red or scarlet hips.

Thoreav: Summer.

There is something in the music of the cow-bell sweeter and more nutritious than the milk which the farmers drink.

THoreav: Summer. 


\section{JUNE}

\section{5}

Mountain Laurel; Wild Rose (various species). 


\section{JUNE}

\section{I7}

The fog condenses into fountains and streams of music, as in the strain of the bobolink which I hear, and runs off so. The music of the birds is the tinkling of the rills that flow from it. I cannot see twenty rods. ...

There is everywhere dew on the cobwebs, little gossamer veils or scarfs as big as your hand dropped from the shoulders of fairies that danced on the grass the past night. ... I think it was this thin vapor that produced a kind of mirage when I looked over the meadow from the railroad last night toward Trillium wood, giving to the level meadow a certain liquid, sea-like look.

Thoread: Summer.

\section{8}

Going up Pine Hill, disturbed a partridge and her brood. She ran in dishabille directly to me, within four feet, while her young, not larger than chickens just hatched, dispersed, flying along a foot or two from the ground, just over the bushes, for a rod or more. The mother kept close at hand to attract my attention, and mewed and clucked, and made a noise as when a hawk is in sight. She stepped about and held her head above the bushes, and clucked just like a hen. What a remarkable instinct, that which keeps the young so silent, and prevents their peeping and betraying themselves! This wild bird will run almost any risk to save her young.

Thoreau: Summer. 


\section{JUNE}

17

Pogonia (P. ophioglossoides).

18

Common Self-hoal 


\section{JUNE}

I9

In the sproutland beyond the red huckleberry, an indigo-bird, which chirps about me, as if it had a nest there. This is a splendid and marked bird, high-colored as is the tanager, looking strange in this latitude. Glowing indigo. It flits from the top of one bush to another, chirping as if anxious. Wilson says it sings, not like most other birds, in the morning and evening chiefly, but also in the middle of the day. In this I notice it is like the tanager, the other fiery-plumaged bird. They seem to love the heat. It probably had its nest in one of these bushes.

Thoreav: Summer.

\section{0}

Instinctively our feet turned up the path to the oven-bird's nest, so narrow that we brushed a shower from every bush. There he was, singing at that moment. "Teacher! teacher! teacher!" he called, with head thrown up and wings drooped. And then while we looked up he left his perch, and passed up between the branches out of our sight, his sweet ecstatic love-song floating down to delight our souls.

Olyve Thorne Mrluer: Little Brothers of the Air.

Again I scent the white lily, and a season I had waited for has arrived. How indispensable all these experiences to make up the summer !

Thoreav: Summer. 
JUNE

19

White Azalea.

20

Water-lily. 


\section{JUNE}

\section{I}

Exquisitely beautiful, and unlike anything we have, is the first white lily just expanded in some shallow lagoon where the water is leaving it, perfectly fresh and pure before the insects have discovered it. How admirable its purity! How innocently sweet its fragrance! How significant that the rich black mud of our dead stream produces the water lily! Out of that fertile slime springs this spotless purity. It is remarkable that those flowers which are most emblematic of purity should grow in the mud.

Thoreau: Summer.

Or sometimes I watched a pair of hen-hawks circling high in the sky, alternately soaring and descending, approaching and leaving one another, as if they were the embodiment of my own thoughts.

Thoreav: Walden.

How beautiful the solid cylinders of the lambkill now just before sunset, small ten-sided rosy-crimson basins, about two inches above the recurved, drooping, dry capsules of last year, and sometimes those of the year before, two inches lower.

Thoreau: Summer. 


\section{JUNE}

2 I

Four-leaved Loosestrife; Spreading Dogbane.

22 


\section{JUNE}

\section{3}

He saw beneath dim aisles, in odorous beds, The slight Linnæa hang its twin-born heads, And blessed the monument of the man of flowers, Which breathes his sweet fame through the northern bowers.

Emersos: Woodnotes.

Of all bird voices, none are more sweet and cheerful to my ear than those of swallows, in the dim, sun-streaked interior of a lofty barn; they address the heart with even a closer sympathy than robin redbreast.

Hawthorne: Mosses from an Old Manse.

\section{4}

Find the great fringed orchis out apparently two or three days, two are almost fully out, two or three only budded; a large spike of peculiarly delicate, pale purple flowers growing in the luxuriant and shady swamp, amid hellebores, ferns, golden senecio, etc. It is remarkable that this, one of the fairest of all our flowers, should also be one of the rarest, for the most part not seen at all. .. How little relation between our life and its!... The seasons go by, to us, as if it were not. A beauty reared in the shade of a convent, who has never strayed beyond the convent bell.

ThoreaU: Summer. 


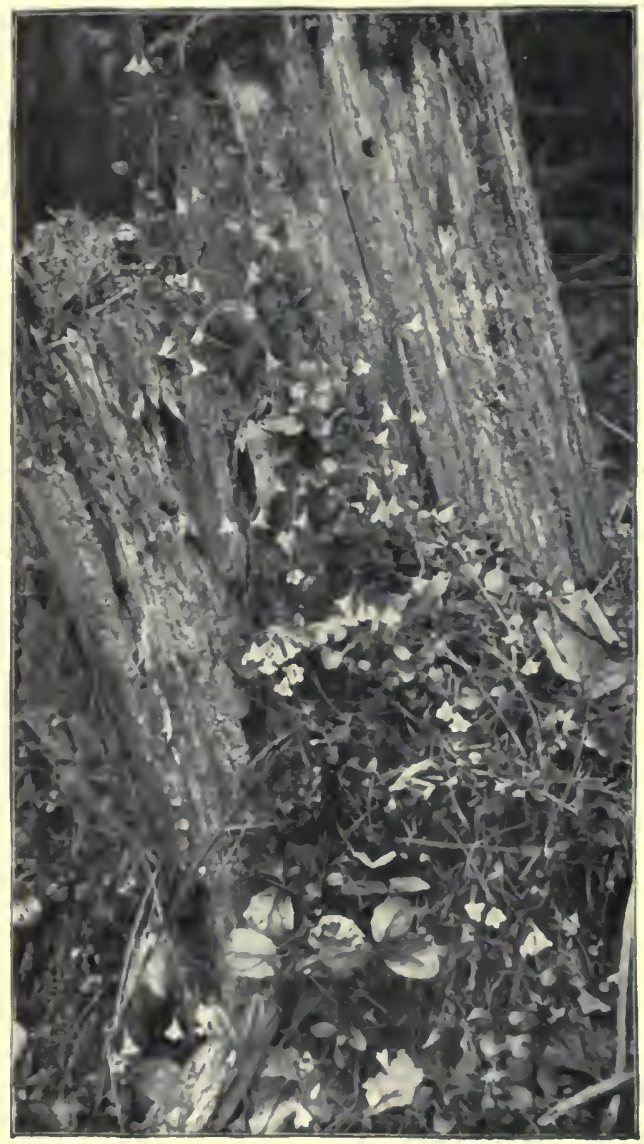





\section{JUNE}

23

Common Elder ; Calopogon.

Wild Indigo ; Common St. John's-wort; Larger Purple FringedOrchis. 


\section{JUNE}

25

"Olive Thorve" Miller, 1831.

The woodchuck is the true serf among the animals; he belongs to the soil, and savors of it. IIe is of the earth, earthy. There is generally a decided odor about his dens and lurking-places, but it is not at all disagreeable in the clorer-scented air; and his shrill whistle, as he takes to his hole or defies the farm dog from the interior of the stone wall, is a pleasant summer sound.

Burrougus: Pepacton.

\section{6}

The sorrel now reddens the fields far and wide. As I look over the fields thus reddened in extensive patches, now deeper, now passing into green, and think of the season now in its prime and heyday, it looks as if it were the blood mantling in the cheek of the beautiful year, - the rosy cheek of its health, its rude June health.

Thoreav: Summer.

Bathing is an undescribed luxury. To feel the wind blow on your body, and the water flow upon you and lave you, is a rare physical enjoyment this hot day.

Thoreav: Summer. 


\section{JUNE}

\section{5}

Hedge Bindweed.

\section{6}

\section{Cone-flower.}




\section{JUNE}

\section{7}

Meanwhile that devil-may-care, the bobolink, Remembering duty, in mid-quaver stops

Just ere he sweeps o'er rapture's tremulous brink,

And 'twixt the winrows most demurely drops,

A decorous bird of business, who provides

For his brown mate and fledglings six besides, And looks from right to left, a farmer mid his crops.

LowelL: An Indian-Summer Reverie.

The pretty little Mitchella repens, with its twin flowers, spots the ground under the pines, its downypetaled, cross-shaped flowers, and its purplish buds.

Thoreav: Summer.

28

He who traverses the woodland paths, at this season, will have occasion to remember the small, drooping, bell-like flowers and slender red stem of the dogsbane ; ... and if "the sun casts such a reflecting heat from the sweet-fern" as makes him faint, when he is climbing the bare hills, as they complained who first penetrated into these parts, the cool fragrance of the swamp pink restores him again, when traversing the valleys between.

Thoreau : A Walk to Wachusett. 


\section{JUNE}

27

Partridge-berty (.Vitchella regens).

28

Meadow-Sweet 


\section{JUNE}

29

We hug the earth, - how rarely we mount! Methinks we might elevate ourselves a little more. We might climb a tree at least. I found my account in climbing a tree once. It was a tall white pine, on the top of a hill; and though I got well pitched, I was well paid for it, for I discovered new mountains in the horizon which I had never seen before, - so much more of the earth and the heavens. ... But, above all, I discovered around me, - it was near the end of June, - on the ends of the topmost branches only, a few minute and delicate red cone-like blossoms, the fertile flower of the white pine looking heavenward.

Thoreav: Walking.

30

Saw a little skunk coming up the river bank in the woods at the white oak, a funny little fellow, about six inclies long and nearly as broad. It faced me and actually compelled me to retreat before it for five minutes. Perhaps I was between it and its hole. Its broad black tail, tipped with white, was erect like a kitten's. It had what looked like a broad white band drawn tight across its forehead or top-head, from which two lines of white ran down one on each side of its back, and there was a narrow white line down its snout.

Thoreav: Summer. 


\section{JUNE}

29

Tall Meadow-Rue; Swamp Loosestrife (Lysimachia stricta).

Great Willow-herb; Pipsissewa ; Round-leaved Pyrola. 


\section{JULY}

The long, narrow, open intervals in the woods near the Assabet are quite dry now, in some parts yellow with the upright loosestrife. One of these meadows, a quarter of a mile long by a few rods wide, narrow and winding, and bounded on all sides by maples showing the under-sides of their leaves, swamp white-oaks, with their glossy darkgreen leaves, birches, etc., and full of meadowsweet just coming into bloom, and cranberry vines, and a dry kind of grass, is a very attractive place to walk in.

Thoreau: Summer.

\section{2}

To-day the milk-weed is blossoming. Some of the raspberries are ripe, the most innocent and simple of fruits, the purest and most ethereal. Cherries, too, are ripe.

Thoread: Summer.

Now, just before sundown, a nighthawk is circling implike with undulating, irregular flight over the sproutland on the Cliff Hill with an occasional squeak, and showing the spot on his wings.

Thoreau: Summer. 


\section{JULY}

Chicory; Indian Pipe; Blue Vervain; Chestnut.

Common Milkweed. 


\section{JULY}

In the night the eyes are partly closed or retire into the head. Other senses take the lead. The walker is guided as well by the sense of smell. Every plant and field and forest emits its odor now, swamp-pink in the meadow and tansy in the road; and there is the peculiar dry scent of corn which has begun to show its tassels. The senses both of hearing and smelling are more alert. We hear the tinkling of rills which we never detected before. From time to time, high up on the sides of hills, you pass through a stratum of warm air.

THoreau: Night and Moonlight.

4

Nathaniel Hawthorne, 1804.

At Potter's sand bank, the sand, though cold on the surface, begins to be warm two inches beneath, and the warmth reaches at least six inches deeper. The tortoise buries her eggs just deep enough to secure this greatest constant warmth.

I passed into and along the bottom of a lake of cold and dewy evening air. Anon, as I rise higher, here comes a puff of warm air, trivially warm, a straggler from the sun's retinue, now buffeted about by the vanguard night breezes.

Thoreav. Summer. 


\section{JULY}

3

Common Evening Primrose.

4

Wild Red Raspberries ripen. 


\section{JULY}

\section{5}

I picked a handful or two of blueberries. These and huckleberries deserve to be celebrated, such simple, wholesome, universal fruits, food for the gods and for aboriginal men. They are so abundant that they concern our race much. Tournefort called some of this genus at least, Vitis-Idaca, which apparently means the vine of Mount Ida. I carnot imagine any country without this kind of berry. Berry of berries, on which men live like birds, still covering our hills as when the red men lived here. Are they not the principal wild fruit?

Thoreau: Summer.

\section{6}

Alexaxder Wrlson, 1766.

The Chimaphila umbellata, winter-green, must have been in blossom some time. The back side of its petals, "cream-colored, tinged with purple," which is turned toward the beholder, while the face is toward the earth, is the handsomer. It is a very pretty little chandelier of a flower, fit to adorn the forest floor. Its buds are nearly as handsome. They appear to be long in unfolding.

THoreaU: Summer. 


\section{JULY}

5

Dwarf Blueberries ripen.

Pickerel-weed.

6 
And now I see an army of skaters advancing in loose array, chasseurs or scouts, as Indian allies are drawn in old books. Now the rays of the sun have reached my seat, a few feet above the water. Flies begin to buzz, mosquitoes to be less troublesome. . . . The birds begin to sing generally, and if not loudest, at least most noticeably on account of the quietness of the hour, a few minutes before sunrise. They do not sing so incessantly and earnestly, as a regular thing, half an hour later.

Thoreau: Summer.

8

One of the nighthawk's eggs is hatched. The young is unlike any that I have seen, exactly like a pinch of rabbit's fur, or down of that color, dropped on the ground, not two inches long, with a dimpling, somewhat regular arrangement of minute feathers in the middle, destined to become the wings and tail. Yet it even half opened its eye, and peeped, if I mistake not. Was ever bird more completely protected, both by the color of its eggs and of its own body that sits on them, and of the young bird just hatched? . . . There was one egg still, and by the side of it this little pinch of down glattened out and not observed at first.

THoreaU: Summer. 


\section{JULY}

\section{7}

Thimbleberries ripen.

Common Mullein.

8

Butter-and-Eggs. 


\section{JULY}

9

The wood thrush's is no opera music; it is not so much the composition as the strain, the tone that interests us, cool bars of melody from the atmosphere of everlasting morning or evening. .... In the pewee's note there is some sultriness, but in the thrush's, though heard at noon, there is the liquid coolness of things drawn from the bottom of springs. The thrush's alone declares the immortal wealth and vigor that is in the forest. . . . Most other birds sing, from the level of my ordinary cheerful hours, a carol, but this bird never fails to speak to me out of an ether purer than that I breathe, of immortal vigor and beauty.

Thoreav: Summer.

10

In one somewhat muddier place close to the shore I came upon an old pout cruising with her young. She dashed away at my approach, but the fry remained. ... They were constantly moring about in a somewhat circular or rather lenticular school, about fifteen or eighteen inches in diameter, and I estimated that there were at least one thousand of them. Presently the old pout came back and took the lead of her brood, which followed her, or rather gathered about her, like chickens about a hen; but this mother had so many children she did n't know what to do. Her maternal yearnings must be on a great scale.

THOREAU: Summer. 


\section{JULY}

9

10

Monkey-flower (Mimulus ringens); Jewel-weed or Spotted Touch-menot. 


\section{JULY}

\section{I}

I meet to-day with a wood-tortoise which is eating the leaves of the early potentillas, and soon after another . . . deliberately eating sorrel. ... It continued to eat when I was within a few feet, holding its head high and biting down at it, each time bringing away a piece of the leaf. It made you think of an old and sick tortoise eating some salutary herb to cure itself with, and reminded me of the stories of the ancients, who, I think, made the tortoises thus cure themselves with dittany or origanum when bitten by a venomous snake.

Thoreav: Summer.

\section{2}

Henry David Thoreau, 1817.

He saw the partridge drum in the woods;

He heard the woodcock's evening hymn;

He found the tawny thrushes' broods,

And the shy hawk did wait for him;

What others did at distance hear,

And guessed within the thicket's gloom,

Was shown to this philosopher,

And at his bidding seemed to come.

EMErsox: Woodnotes.

Hast thou named all the birds without a gun?

Loved the wood-rose, and left it on its stalk?

EMErson: Forbearance. 


\section{JULY}

I I

High-bush Blueberries ripen.

12

Wild Yellow Lily. 


\section{JULY}

\section{3}

A bittern leaves the shore at my approach. A nighthawk squeaks and booms before sunrise. . . I hear the blackbird's conqueree, and the kingfisher darts away with his alarum and outstretched neck.

Thoreav: Summer.

When the yellow lily flowers in the meadows, and the red in dry lands and by woodpaths, then, methinks, the flowering season has reached its height. They surprise me as perhaps no more can. Now I am prepared for anything.

THOREAU: Summer.

\section{4}

As we come in sight of the lilies, where they cover the water at the outlet of the lake, a brisk gust of wind, as if it had been waiting to surprise us, sweeps down and causes every leaf to leap from the water and show its pink underside. Was it a fluttering of hundreds of wings, or the clapping of a multitude of hands? But there rocked the lilies with their golden hearts open to the sun, and their tender white petals as fresh as crystals of snow. What a queenly flower, indeed, the type of unsullied purity and sweetness! Its root, like a black, corrugated, ugly reptile, clinging to the slime, but its flower in purity and whiteness like a star.

BURroughs: Riverby. 


\section{JULY}

13

Wild Red Lily.

Downy False Foxglove; Horned Bladderwort. 


\section{JULY}

\section{5}

I find an Attacus luna half hidden under a skunkcabbage leaf, with its back to the ground and motionless, on the edge of a swamp. The underside is a particularly pale, hoary green. It is somewhat greener above, with a slightly purplish brown border on the front edge of its front wings, and a brown, yellowish, and whitish eye-spot in the middle of each wing. It is very sluggish, and allows me to turn it over and cover it up with another leaf, sleeping till the night comes. It has more relation to the moon by its pale, hoary green color, and its sluggishness by day, than by the form of its tail.

ThoreaU: Summer.

\section{I6}

The sandpiper tilts along the shelving shore. Out of an embowered harbor a wood duck convoys her fleet of ducklings, and on the ripples of their wake the anchored argosies of the water lilies toss and cast adrift their cargoes of perfume. Above them the green heron perches on an overhanging branch, uncouth but alert, whether sentinel or scout, flapping his awkward way along the ambient bends and reaches. With slow wing-beats he signals the coming of some more lazily moving boat, that drifts at the languid will of the current or indolent pull of oars that grate on the goldenmeshed sand and pebbles.

Robisson: In New England Fields and Woods. 


\section{JULY}

I 5

Low Blackberries and Black Huckleberries ripen.

Checkerberry. 


\section{I7}

There are many interesting objects of study, as you walk up and down a clear river like this in the water, where you can see every inequality in the bottom, and every object on it. The breams' nests are interesting and even handsome, and the shallow water in them over the sand is so warm to my hand that I think their ova will soon be hatched; also, the numerous heaps of stones, made I know not certainly by what fish, many of them rising above the surface. . . The bottom is also scored with furrows made by the clams moving about, sometimes a rod long, and always the clam lies at one end.

Thoreau: Summer.

\section{8}

Gilbert White, 1720.

About ten o'clock, - when man is asleep, and day fairly forgotten, - the beauty of moonlight is seen over lonely pastures where cattle are silently feeding. On all sides novelties present themselves. Instead of the sun there are the moon and stars, instead of the wood thrush there is the whip-poorwill, - instead of butterflies in the meadows, fireflies, winged sparks of fire I who would have believed it?... Instead of singing birds the half throttled note of a cuckoo flying over, the croaking of frogs, and the intenser dream of crickets.

Thoreau: Night and Moonlight. 


$$
\text { JULY }
$$

17

Meadow Beauty.

IS

Common Arrowhead. 


\section{JULY}

In the erening, if you walk through the dusking fields or by the deeper-shadowed wood borders, an enchanted bird flits on before you, lighting now on the fence rail, now on some conspicuous stone, and thence throwing out a lure of brief, sweet melody touched by twilight and the dew. This is the vesper sparrow.

Edith M. Thомаs: Birds and "Birds."

The bullfrogs trump to usher in the night, and the note of the whip-poor-will is borne on the rippling wind from over the water. Sympathy with the fluttering alder and poplar leaves almost takes away my breath ; yet, like the lake, my serenity is rippled but not ruffled. These small wares raised by the evening wind are as remote from storm as the smooth reflecting surface. Though it is now dark, the wind still blows and roars in the wood, the waves still dash, and some creatures lull the rest with their notes. The repose is never complete.

THOREAU: Walden. 
JULY

19

Hardhack.

20

Button-bush. 


\section{JULY}

2 I

I wonder if any Roman emperor ever indulged in such a luxury as this, - of walking up and down a river in torrid weather with only a hat to shade the head. ... Now we traverse a long watery plain some two feet deep; now we descend into a dark river valley, where the bottom is lost sight of and the water rises to our armpits; now we go over a hard iron pan; now we stoop and go under a low bough of the Salix nigra; now we slump into soft mud, amid the pads of the Nymphora odorata, at this hour shut.... We finally return to the dry land and recline in the shade of an apple-tree on a bank overlooking the meadow.

Thoreav: Summer.

22

I climbed a hill path strange and new With slow feet, pausing at each turn;

A sudden waft of west wind blew

The breath of the sweet fern.

That fragrance from my vision swept The alien landscape; in its stead, Up fairer hills of youth I stepped, As light of heart as tread.

Whittier: Sweet Fern. 
JULY

2 I

22 


\section{JULY}

23

Regularly at half past seven, in one part of the summer, after the evening train had gone by, the whip-poor-wills chanted their vespers for half an hour, sitting on a stump by my door, or upon the ridgepole of the house. ... I had a rare opportunity to become acquainted with their habits. Sometimes I heard four or five at once in different parts of the wood, by accident one a bar behind another, and so near me that I distinguished not only the cluck after each note, but often that singular buzzing sound like a fly in a spider's web, only proportionally louder.

Thoreav: Walden.

\section{4}

As I bent over a pool, taking now and then a sip of the icy water, a small trout suddenly jumped near the foot of the fall below. He was intensely busy working about in the edge of the falling water, where rising bubbles and whirling foam half concealed him. In color he looked not unlike a beech leaf, and he moved so constantly that only an attentive eye could distinguish him from the waste of the stream whirled about in the eddies. . . . His eagerness and restlessness seemed born of the restlessness of the stream and the keen temperature of the water in which he lived.

Bolles: At the North of Bearcamp Water. 
JULY

23

24

Common Tansy. 


\section{JULY}

\section{5}

I have passed down the river before sunrise on a summer morning, between fields of lilies still shut in sleep; and when, at length, the flakes of sunlight from over the bank fell on the surface of the water, whole fields of white blossoms seemed to flash open before me, as I floated along, like the unfolding of a banner, so sensible is this flower to the influence of the sun's rays.

Thoreau: A Week on the Concord and Merrimack Rivers."

\section{6}

That note from the thicket is the whip-poorwill's. What in all the vocalities of Nature is there to compare with this voice of the cool and the dusk, this cloistered melodist, who was never yet heard in the profane courts of Day? It is " most musical, most melancholy," a not unworthy rival of the English nightingale. Yet close by the whip-poor-will's covert one hears what might be called the mechanical process of his song - a harsh, unlubricated whir, or rattle, which suggests a laryngean ailment of some sort, as, in the same way, the wild dove's note, heard close by, suggests asthmatic breathing.

Edith M. Thomas: The Round Year. 


\section{JULY}

25

26

Early Goldenrod (Solidago juncea). 


\section{JULY}

But when vivid color is wanted, what can surpass or equal our cardinal-flower? There is a glow about this flower as if color emanated from it as from a live coal. The eye is baffled, and does not seem to reach the surface of the petal; it does not see the texture or material part as it does in other flowers, but rests in a steady, still radiance. It is not so much something colored as it is color itself. And then the moist, cool, shady places it affects, usually where it has no floral rivals, and where the large, dark shadows need just such a dab of fire ! Often, too, we see it double, its reflected image in some dark pool heightening its effect.

Burrovgrs: Riverby.

28

As the light is obscured after sunset, the birds rapidly cease their songs, and the swallows cease to flit over the river. Soon the bats are seen taking the places of the swallows, and flying back and forth like them, and commonly a late kingbird will be heard twittering still in the air. After the bats, or half an hour after sunset, the water bugs begin to spread themselves over the stream (though fifteen minutes earlier not one was seen without the pads), now when it is difficult to see them or the dimples they make, except you look toward the reflected western sky.

Thoreau: Summer. 


\section{JULY}

27

Cardinal-flower; Poke.

28 


\section{JULY}

\section{9}

When other birds are still the screech owls take up the strain, like mourning women their ancient u-lu-lu. Their dismal scream is truly Ben Jonsonian. Wise midnight hags! It is no honest and blunt tu-whit tu-who of the poets, but, without jesting, a most solemn graveyard ditty, the mutual consolations of suicide lovers remembering the pangs and the delights of supernal love in the infernal groves.

Thoreau: Walden.

30

Sit down upon some moss-covered log, or against some small tree, a sapling maple for instance, only let it be something behind which you can look without too much trouble, and keep perfectly still. You will not have to wait long, and you will catch the indefinable speech of softly swaying limbs above or behind you. Wait a moment: there it is again; the rhythm of lightly bending sprays of hemlock. Look quickly up and you will see the self-same squirrel that was hiding a moment before, making his way through the hemlock-tops, with here and there a running leap, with tail spread out to its fullest width behind for a rudder.

Sylvester: Homestead Highways. 


\section{JULY}

29

Common Clematis.

30

Common Thistle. 
One day when I went out to my wood-pile, or rather my pile of stumps, I observed two large ants, the one red, the other much larger, nearly half an inch long, and black, fiercely contending with one another. Having once got hold they never let go, but struggled and wrestled and rolled on the chips incessantly. Looking farther, I was surprised to find that the chips were covered with such combatants, that it was not a duellum, but a bellum, a war between two races of ants, the red always pitted against the black, and frequently two red ones to one black. The legions of these myrmidons covered all the hills and vales in my wood-yard, and the ground was already strewn with the dead and dying, both red and black. . . . On every side they were engaged in deadly combat, yet without any noise that I could hear, and human soldiers never fought so resolutely.

Thoreav: Walden. 
JULY

31 


\section{AUGUST}

Come, whether the Muse will go with us or prefers to remain in tamer fields, come away to the "slashing," where the Maryland yellow-throat warns the visitor with "Witches here! Witches here!" where the geometric spider constructs her silken theorems on the largest scale, where poke and silkweed make prodigious growth, and where a not mythic Briareus holds out in his hundred scraggy hands a sweet and spicy lure. In order to prize the blackberry at its full worth it must be wrested from the ogreish genius by single-handed contest.

Edith M. Thomas : The Round Year.

The bullfrogs begin with one or two notes, and with each peal add another trill to their trump, er-roonk - er-er-roonk - er-er-er-roonk, etc. I am amused to hear one after another, and then an unexpectedly deep and confident bass, as if he had charged himself with more wind than the rest. And now, as if by a general agreement, they all trump together, making a deafening noise.... Suddenly a tree-toad in the overhanging woods begins, and another answers, and another, with loud ranging notes, such as I never heard before, and in three minutes they are all silent again.

THoread: Summer. 


\section{AUGUST}

I

High-bush Blackberries ripen.

White Alder (Clethra alnifolia).

Pearly Everlasting. 


\section{AUGUST}

3

This small lake was of most value as a neighbor in the intervals of a gentle rainstorm in August, when, both air and water being perfectly still, but the sky overcast, mid-afternoon had all the serenity of evening, and the wood thrush sang around, and was heard from shore to shore. A lake like this is never smoother than at such a time; and the clear portion of air above it being shallow and darkened by clouds, the water, full of light and reflections, becomes a lower heaven itself so much the more important.

Thoreav: Walden.

4

Burly, dozing humble-bee, Where thou art is clime for me.

Let them sail for Porto Rique, Far-off heats through seas to seek;

I will follow thee alone, Thou animated torrid-zone!

Zigzag steerer, desert cheerer, Let me chase thy waving lines; Keep me nearer, me thy hearer, Singing over shrubs and vines.

Emerson: The Humble-Bee. 


\section{AUGUST}

3

4

Aster (A, umbellatus). 


\section{AUGUST}

\section{5}

Our American goldfinch is one of the loveliest of birds. With his elegant plumage, his rhythmical, undulatory flight, his beautiful song, and his more beautiful soul, he ought to be one of the best beloved, if not one of the most famous. . . . He is like the clickadee, and yet different. He is not so extremely confiding, nor should I call him merry. But he is always cheerful, in spite of his so-called plaintive note, from which he gets one of his names, and always amiable. So far as I know, he never utters a harsh sound; even the young ones, asking for food, use only smooth, musical tones.

Torrey: Birds in the Bush.

\section{6}

Early apples begin to be ripe about the first of August; but I think that none of them are so good to eat as some to smell. One is worth more to scent your handkerchief with than any perfume which they sell in the shops. The fragrance of some fruits is not to be forgotten, along with that of flowers. Some gnarly apple which I pick up in the road reminds me by its fragrance of all the wealth of Pomona, - carrying me forward to those days when they will be collected in golden and ruddy heaps in the orchards and about the cidermills.

ThoREAU: Wild Apples. 


\section{AUGUS'T}

5

Lance-leaved Goldenrod; Turtle-head. 


\section{AUGUST}

\section{7}

August is the month of the high-sailing hawks. The hen-hawk is the most noticeable. He likes the haze and calm of these long, warm days. He is a bird of leisure, and seems always at his ease. How beautiful and majestic are his movements ! So self-poised and easy, such an entire absence of haste, such a magnificent amplitude of circles and spirals, such a haughty, imperial grace, and, occasionally, such daring aerial evolutions !

Burrovghs: Wake-Robin.

8

Very warm. This melting weather makes a stage in the year. The crickets creak louder and more steadily. . . . The dry z-ing of the locust is heard. The drouth begins. Bathing cannot be omitted. The conversation of all boys in the streets is whether they will or will not, or who will, go in a-swimming. . . . The North River, Assabet, by the old stone bridge, affords the best bathing-place I think of, - a pure, sandy, uneven bottom, with a swift current, a grassy bank, and overhanging maples, transparent water, deep enough, where you can see every fish in it.

Thoreav: Summer. 


\section{AUGUST}

7

8

Ground-nut or Wild Bean (Apios tuberosa). 


\section{AUGUST}

9

The fireflies in the meadows are very numerous, as if they had replenished their lights from the lightning. The far-retreated thunder-clouds low in the southeast horizon and in the north, emitting low flashes which reveal their forms, appear to lift their wings like fireflies, or it is a steady glare like the glow-worm. Wherever they go, they make a meadow.

ThoreaU: Summer.

\section{IO}

When a storm is brewing among the hills after a sultry forenoon, it is field-day on the uplands for the swift-winged swallows, who hardly wait for mid-day to get well past before they begin their multiplex gyrations, shooting in and out among the hay-makers, scouring the stubble for insects, with many a shrill, clear whistle and fife-like note, dodging here and there, now high, now low, sweeping, skimming, and curveting over and among the orchard treetops with arrowy, graceful flight, their coats of polished purple gleaming in the afternoon sun with every dip and rise a-wing like bits of blued steel.

Sylvester: Homestead Highways. 


\section{AUGUST}

9

Slender Gerardia.

10

Joe-Pye Weed. 


\section{AUGUST}

\section{I}

The lustre of the season begins to dim, the foliage of the trees and woods to tarnish, the plumage of the birds to fade, and their songs to cease. The hints of approaching fall are on every hand. How suggestive this thistledown, for instance, which, as I sit by the open window, comes in and brushes softly across my hand! The first snowflake tells of winter not more plainly than this driving down heralds the approach of fall. Come here, my fairy, and tell me whence you come and whither you go? What brings you to port here, you gossamer ship sailing the great sea?

Burroughs: Winter Sunshine.

\section{2}

Editi M. Thomas, 1854.

The nighthawk circled overhead in the sunny afternoons - for I sometimes made a day of it like a mote in the eye, or in heaven's eye, falling from time to time with a swoop and a sound as if the heavens were rent, torn at last to very rags and tatters, and yet a seamless cope remained; small imps that fill the air and lay their eggs on the ground on the bare sand or rocks on the tops of hills, where few have found them; graceful and slender like ripples caught up from the pond, as leaves are raised by the wind to float in the heavens; such kindredship is in Nature.

Tiroreav: Walden. 
AUGUST

II

I 2

Swainp Rose-Mallow. 


\section{AUGUST}

13

Nothing that May puts into her lap is more exquisite than are the purple gerardias with which August and September embroider the pasture and the woodland road. They have not the sweet breath of the arbutus, nor even the faint elusive odor of the violet, but for daintiness of form, perfection of color, and gracefulness of habit it would be impossible to praise them too highly. Of our three species, my own favorite is the one of the narrow leaves (Gerardia tenuifolia), its longer and slighter flower-stems giving it an airiness and grace peculiarly its own.

TorreY: The Foot-Path Way.

\section{I4}

Might we not have more confidential relations with the Lake, more official knowledge, if we tried to get our living therefrom? The sandpiper has this advantage over us. He runs like a fly along the wet sand, his line of travel a series of scallops bounded by the coming and receding of the waves. Sometimes, "for fun," he lets the water overtake and wash around his slender legs. He runs well, but cannot maintain a graceful standing position; for he seems to have the centre of gravity misplaced, always nodding and swaying (tip-up, teeter), as though shaken by the wind, or troubled with a St. Vitus's dance.

Epith M. Thomas: The Round Year. 


\section{AUGUST}

13

Purple Gerardia (G. purpurea and var. paupercula).

14 


\section{AUGUST}

\section{5}

\section{JoHX TORREX, 1796.}

Rana sylvatica, the wood-frog, betrayed himself by leaping over the dry beech leaves. I followed him quickly as he sought to elude me. Not only were his leaps long, but his skill in doubling was something marvelous. His second jump was generally at right angles with the first, and thrice he no sooner struck the ground than he turned and rebounded upon his tracks, so that he passed over or between my feet.

Bolles: At the North of Bearcamp Water.

\section{I6}

I see a pickerel in the brook showing his whitish, greedy upper lips projecting over the lower. How well concealed he is. He is generally of the color of the muddy bottom, or the decayed leaves and wood that compose it, and the longitudinal light stripe on his back, and the transverse ones on his sides are the color of the yellowish sand here and there exposed. He heads up stream and keeps his body perfectly motionless, however rapid the current, chiefly by the motion of his narrow pectoral fins, though also by the waving of his other fins and tail as much as is necessary, a motion which a frog might mistake for that of weeds.

Thoreav: Summer. 


\section{AUGUST}

I 5

Elderberries ripen.

16

Ladies' Tresses (Spiranthes cernua). 


\section{AUGUST}

\section{I7}

The leaves of the elms on the dry highways begin to roll up. I have to lift my hat to let the air cool my head. But I find a refreshing breeze from over the river and meadow. In the hottest day you can be comfortable in the shade on the open shore of a pond or river, where a zephyr comes over the water sensibly cooled by it; that is, if the water is deep enough to cool it.

Thoreau: Summer.

\section{8}

Thoreau speaks of rain waking the lichens into life, and we saw this as never before. Not only does it bring out the colors and give a brightness and richness they show at no other time, but it raises the leaves - if one may so call themmakes them stand out fresh. The beeches were marvelous with many shades of green, and of pink, from a delicate blush over the whole tree, to bright vermilion in small patches. . . Every hollow under the trees had become a clear pond to reflect these beauties, and lively little brooks ripple across the path, adding to the woods the only thing they lacked, - running water.

Olive Thorne Miller: Little Brothers of the Air. 
AUGUST

17

18 


\section{AUGUST}

I9

The pine wood loves a clean floor, and is intolerant of undergrowth. Grasses and sedges, with all bushes, it frowns upon, as a model housekeeper frowns upon dirt. A plain brown carpet suits it best, with a modest figure of green - preferably of evergreen - woven into it; a tracery of partridgeberry vine, or, it may be, of club moss, with here and there a tuft of pipsissewa and pyrola. Its mood is sombre, its taste severe.

Torrey: The Foot-Path Way.

I love to hear thine earnest voice,

Wherever thou art hid,

Thou testy little dogmatist,

Thou pretty Katydid!

Thou mindest me of gentlefolks, -

Old gentlefolks are they, -

Thou say'st an undisputed thing

In such a solemn way.

Holmes: To an Insect. 
AUGUST

19

20 


\section{AUGUST}

2 I

The Purple Grass (Eragrostis pectinacea) is now in the height of its beauty. I remember still when I first noticed this grass particularly. Standing on a hillside near our river, I saw, thirty or forty rods off, a stripe of purple half a dozen rods long, under the edge of a wood, where the ground sloped toward a meadow.... On going to and examining it, I found it to be a kind of grass in bloom, hardly a foot high, with but few green blades, and a fime spreading panicle of purple flowers, a shallow, purplish mist trembling around me.

Thoreav: Autumnal Tints.

\section{2}

Along the roadside, like the flowers of gold That tawny Incas for their gardens wrought, Heavy with sunshine droops the goldenrod, And the red pemmons of the cardinal-flowers Hang motionless upon their upright staves. The sky is hot and hazy, and the wind, Wing-weary with its long flight from the south, Unfelt ; yet, closely scamned, yon maple leaf With faintest motion, as one stirs in dreams, Confesses it. The locust by the wall Stabs the noon-silence with his sharp alarm. Whittier: Among the Hills. 


\section{AUGUST}

2 I

22 


\section{AUGUST}

\section{3}

Cuvier, 1769.

For the last two or three days, I have found scattered stalks of the cardinal-flower, the gorgeous scarlet of which it is a joy even to remember. The world is made brighter and sunnier by flowers of such a hue. Even perfume, which otherwise is the soul and spirit of a flower, may be spared when it arrays itself in this scarlet glory. It is a flower of thought and feeling, too; it seems to have its roots deep down in the hearts of those who gaze at it. Other bright flowers sometimes impress me as wanting sentiment; but it is not so with this.

Hawthorve: American Note-Books.

\section{4}

Now we coasted along some shallow shore by the edge of a dense palisade of bulrushes, which straightly bounded the water as if clipped by art, reminding us of the reed forts of the East-Indians of which we had read; and now the bank, slightly raised, was overhung with graceful grasses and various species of brake, whose downy stems stood closely grouped and naked as in a vase, while their heads spread several feet on either side. The dead limbs of the willow were rounded and adorned by the climbing mikania, which filled every crevice in the leafy bank.

Thoreav: A Week on the Concord and Merrimack Rivers. 


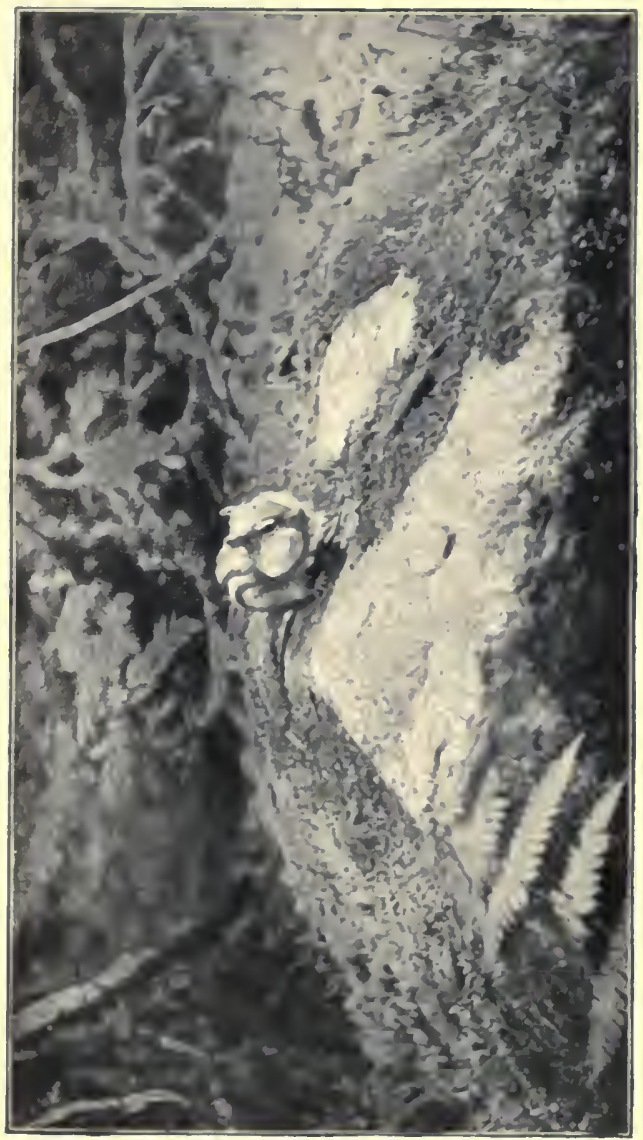



AUGUST

23

24 


\section{AUGUST}

\section{5}

As you look over the pond westward you are obliged to employ both your hands to defend your eyes against the reflected as well as the true sun, for they are equally bright; and if, between the two, you survey its surface critically, it is literally as smooth as glass, except where the skater insects, at equal intervals scattered over its whole extent, by their motions in the sun produce the finest imaginable sparkle on it, or, perchance, a duck plumes itself, or ... a swallow skims so low as to touch it.

Troneau: Walden.

\section{6}

The small rose-colored polygonum raised its head proudly above the water on either hand, and flowering at this season and in these localities, in front of dense fields of the white species which skirted the sides of the stream, its little streak of red looked very rare and precious. The pure white blossoms of the arrow-head stood in the shallower parts, and a few cardinals on the margin still proudly surveyed themselves reflected in the water, though the latter, as well as the pickerel-weed, was now nearly out of blossom.

Thoreau: A Week on the Concord and Merrimack Rivers. 
AUGUST

25

26 


\section{AUGUST}

\section{7}

I made quite an excursion up and down the river in the water, a fluvial . . . walk. It seemed the properest highway for this weather, now in water a foot or two deep, now suddenly descending through valleys up to my neck, but all alike agreeable.

Thoreau: Summer.

Dense flocks of blackbirds were winging their way along the river's course, as if on a short evening pilgrimage to some shrine of theirs, or to celebrate so fair a sunset.

Thoread: A Week on the Concord and Merrimack Rivers.

\section{8}

Formerly I had come to this pond adventurously, from time to time, in dark summer nights, with a companion, and making a fire close to the water's edge, which we thought attracted the fishes, we caught pouts with a bunch of worms strung on a thread, and when we had done, far in the night, threw the burning brands high into the air like skyrockets, which coming down into the pond, were quenched with a loud hissing, and we were suddenly groping in total darkness. Through this, whistling a tune, we took our way to the haunts of men again.

Thoreav: Walden. 
AUGUST

27

28 


\section{AUGUST}

\section{9}

Ouiver Wendell Holmes, 1809.

Frogs appear slow to make up their minds, but then they act precipitately. As long as they are here, they are here, and express no intention of removing. But the idea of removing fills them instantaneously, as Nature, abhorring, fills a vacuum. Now they are fixed and imperturbable like the sphinx, and now they go off with short, squatty leaps over the spatterdock on the irruption of the least idea.

Thoreau: Summer.

\section{0}

If you want to know how good salt is, see a cow eat it. She gives the true saline smack. How she dwells upon it, and gnaws the sward and licks the stones where it has been deposited! The cow is the most delightful feeder among animals. It makes one's mouth water to see her eat pumpkins, and to see her at a pile of apples is distracting. How she sweeps off the delectable grass! The sound of her grazing is appetizing; the grass betrays all its sweetness and succulency in parting under her sickle.

Burrovgrs: Signs and Seasons. 


\section{AUGUST}

29

30 


\section{AUGUST}

\section{1}

These experiences were very memorable and valuable to ine, - anchored in forty feet of water, and twenty or thirty rods from the shore, surrounded sometimes by thousands of small perch and shiners, dimpling the surface with their tails in the moonlight, and communicating by a long flaxen line with mysterious nocturnal fishes which had their dwelling forty feet below, or sometimes dragging sixty feet of line about the pond as I drifted in the gentle night breeze, now and then feeling a slight vibration along it, indicative of some life prowling about its extremity, or dull uncertain blundering purpose there, and slow to make up its mind. At length you slowly raise, pulling hand over hand, some horned pout squeaking and squirming to the upper air.

Thoreav: Walden.

What if we were to mature as perfectly, root and branch, glowing in the midst of our decay, like the Poke! I confess that it excites me to behold them. I cut one for a cane, for I would fain handle and lean on it. I love to press the berries between my fingers, and see their juice staining my hand.

Thoreav: Autumnal Tints. 


\section{AUGUST}

$3 I$ 


\section{SEPTEMBER}

Late in the afternoon we passed a man on the shore fishing with a long birch pole, its silvery bark left on, and a dog at his side ; ... and when we had rowed a mile as straight as an arrow, with our faces turned towards him, and the bubbles in our wake still visible on the tranquil surface, there stood the fisher still with his dog, like statues under the other side of the heavens, the only objects to relieve the eye in the extended meadow; and there would he stand abiding his luck, till he took his way home through the fields at evening with his fish.

Thorenu: A Week on the Concord and Merrimack Rivers.

A marsh hawk in brown plumage comes skimming over the grass. This way and that he swerves in ever graceful lines. For one to whom ease and grace come by nature, even the chase of meadow mice is an act of beauty, while another goes awkwardly though in pursuit of a goddess.

Several times I have noticed a kingfisher hovering above the grass (so it looks, but no doubt he is over an arm of the creek), striking the air with quick strokes, and keeping his head pointed downward, after the manner of a tern. . . . Now I remark him sitting motionless upon the top of a post in the midst of the marsh.

Torrey: A Florida Sketch-Book. 


\section{SEPTEMBER}

I

Summer Grapes, Wild Black Cherries, Beechnuts, Hazel-nuts, and the fruit of the Smooth Sumach ripen.

2 


\section{SEPTEMBER}

Wonderful is human speech, - the work of generations upon generations, each striving to express itself, its feelings, its thoughts, its needs, its sufferings, its joys, its inexpressible desires. Wonderful is human speech, for its complexity, its delicacy, its power. But the pine-tree, under the visitations of the heavenly influence, utters things incommunicable; it whispers to us of things we have never said and never can say, - things that lie deeper than words, deeper than thought. Blessed are our ears if we hear, for the message is not to be understood by every comer, nor indeed, by any, except at happy moments.

Torrex: The Foot-Path Way.

4

The water willow when it is of large size and entire, is the most graceful and ethereal of our trees. Its masses of light-green foliage, piled one upon another to the height of twenty or thirty feet, seemed to float on the surface of the water, while the slight gray stems and the shore were hardly visible between them. No tree is so wedded to the water, and harmonizes so well with still streams. It is even more graceful than the weeping willow, or any pendulous trees which dip their branches in the stream instead of being buoyed up by it.

Thoreav: $A$ Week on the Concord and Merrimack Rivers. 
SEPTEMBER

3

4 


\section{SEPTEMBER}

\section{5}

As we sailed up the river, there was a pretty good-sized pickerel poised directly over the sandy bottom close to the shore, and motionless as a shadow. It is wonderful how they resist the slight current, and remain thus stationary for hours. He no doubt saw us plainly on the bridge, - in the sunny water, his whole form distinct and his shadow, - motionless as the steel-trap which does not spring till the fox's foot has touched it.

Troreau: Days and Nights in Concord.

\section{6}

Though the shadows of the hills were beginning to steal over the stream, the whole river valley undulated with mild light, purer and more memorable than the noon. For so day bids farewell even to solitary vales uninhabited by man. Two herons (Ardea herodias), with their long and slender limbs relieved against the sky, were seen traveling ligh over our heads, - their lofty and silent flight, as they were wending their way at evening, surely not to alight in any marsh on the earth's surface, but perchance on the other side of our atmosphere, a symbol for the ages to study, whether inpressed upon the sky, or sculptured amid the hieroglyphics of Egypt.

Thonenv: A Week on the Concord and Merrimack Rivers. 
SEPTEMBER

5

6 


\section{SEPTEMBER}

\section{7}

Asters and goldenrods were the livery which nature wore at present. The latter alone expressed all the ripeness of the season, and shed their mellow lustre over the fields, as if the now declining summer's sun had bequeathed its hues to them. ... On every hillside, and in every valley, stood countless asters, coreopses, tansies, goldenrods, and the whole race of yellow flowers, like Brahminical devotees, turning steadily with their luminary from morning till night.

Thoreav: A Week on the Concord and Merrimack Rivers.

\section{8}

Shoals of golden and silver minnows rose to the surface to behold the heavens, and then sheered off into more sombre aisles; they swept by as if moved by one mind, continually gliding past each other, and yet preserving the form of their battalion unchanged, as if they were still embraced by the transparent membrane which held the spawn; a young band of brethren and sisters trying their new fins; now they wheeled, now shot ahead, and when we drove them to the shore and cut them off, they dexterously tacked and passed underneath the boat.

ThoreaU: A Week on the Concord and Merrimack Rivers. 
SEPTEMBER

7

8 


\section{SEPTEMBER}

9

Maurice Thompson, 1844.

The woodland paths are never seen to such advantage as in a moonlight night, so embowered, still opening before you almost against expectation as you walk. You are so completely in the woods, and yet your feet meet no obstacles. It is as if it were not a path, but an open, winding passage through the bushes, which your feet find. Now I go by the spring, and when I have risen to the same level as before, find myself in the warmer stratum again. These warmer veins, in a cool evening like this, do not fail to be agreeable.

Thoreav: Summer.

\section{IO}

Thomas Nutrall, died, 1859.

How autumnal is the scent of wild grapes, now by the roadside! The cross-leaved polygala emits its fragrance as at will; you mist not hold it too near, but on all sides and at all distances. The pendulous, drooping barberries are pretty well reddened.

\section{Thoreav: Days and Nights in Concord.}

The gentian (Andrewsii) now generally in prime, on low, moist, shady banks. Its transcendent blue shows best in the shade and suggests coolness; contrasts there with the fresh green; a splendid blue, light in the shade, turning to purple with age.

Thoreau: Autumn. 


\section{SEPTEMBER}

9

IO

Northern Fox Grapes ripen.

Closed Gentian. 


\section{SEPTEMBER}

\section{I}

With our heads so low in the grass, we heard the river whirling and sucking, and lapsing downward, kissing the shore as it went, sometimes rippling louder than usual, and again its mighty current making only a slight limpid, trickling sound, as if our water-pail had sprung a leak, and the water were flowing into the grass by our side. The wind, rustling the oaks and hazels, impressed us like a wakeful and inconsiderate person up at midnight, moving about, and putting things to rights, occasionally stirring up whole drawers full of leaves at a puff.

Troreav: A Week on the Concord and Merrimack Rivers.

\section{2}

Beside a ditch in a field beyond, we find the great blue lobelia, and near it, amid the weeds and wild grasses and purple asters, the most beautiful of our fall flowers, the fringed gentian. What a rare and delicate, almost aristocratic look the gentian has amid its coarse, unkempt surroundings! It does not lure the bee, but it lures and holds every passing human eye.

Burroughs: Pepacton. 


\section{SEPTEMBER}

I I

12

Fringed Gentian. 


\section{SEPTEMBER}

\section{I3}

I am particularly attracted by the motions of the serpent tribe. They make our hands and feet, the wings of the bird, and the fins of the fish seem very superfluous, as if nature had only indulged her fancy in making them. The black snake will dart into a bush when pursued, and circle round and round with an easy and graceful motion, amid the thin and bare twigs, five or six feet from the ground, as a bird flits from bough to bough, or hang in festoons between the forks.

Thoreav: Natural History of Massachusetts.

\section{I4}

Alexander von Humboldt, 1769.

The rain, which had fallen heavily for hours, light and fine now, drew a shimmering veil before the trees, - a veil like a Japanese bead-hanging, which hides nothing, only the rain veil was more diaphanous than anything fashioned by human hands. It did not conceal, but enhanced the charm of everything behind it, lending a glamour that turned the woods into enchanted land.

Olive Thorve Miller: Little Brothers of the Air. 
SEPTEMBER

I 3

14 


\section{SEPTEMBER}

\section{5}

The jays scream and the red squirrels scold while you are clubbing and shaking the chestnuttrees, for they are there on the same errand, and two of a trade never agree. I frequently see a red or gray squirrel cast down a green chestnut-burr, as I am going through the woods, and I used to think, sometimes, that they were cast at me. In fact, they are so busy about it, in the midst of the chestnut season, that you cannot stand long in the woods without hearing one fall.

Thoreav: The Succession of Forest Trees.

\section{6}

The chipping or striped squirrel sat upon the end of some Virginia fence or rider reaching over the stream, twirling a green nut with one paw, as in a lathe, while the other held it fast against its incisors as chisels. Like an independent russet leaf, with a will of its own, rustling whither it could; now under the fence, now over it, now peeping at the voyageurs through a crack with only its tail visible, now at its lunch deep in the toothsome kernel, and now a rod off playing at hide-and-seek, with the nut stowed away in its chops, where were half a dozen more besides, extending its cheeks to a ludicrous breadth.

Thoreau: A Week on the Concord and Merrimack Rivers. 


\section{SEPTEMBER}

\section{5}

Chestnuts ripen.

16 


\section{SEPTEMBER}

\section{7}

Belonging to a genus which is remarkable for the beautiful form of its leaves, I suspect that some scarlet-oak leaves surpass those of all other oaks in the rich and wild beauty of their outlines. . . .

Stand under this tree and see how finely its leaves are cut against the sky, - as it were, only a few sharp points extending from a mid-rib. They look like double, treble, or quadruple crosses. They are far more ethereal than the less deeply scalloped oak-leaves.

Thoreav: Autumnal Tints.

As I sit there, I see the shadow of a hawk flying above and behind me. I think I see more hawks nowadays. Perhaps it is both because the young are grown and their food, the small birds, are flying in flocks and are abundant. I need only sit still a few minutes on any spot which overlooks the river meadows before I see some black circling mote beating along the meadow's edge, now lost for a moment as it turns edgewise in a peculiar light, now reappearing farther or nearer.

Thoread: Autumn. 
SEPTEMBER

17

18 


\section{SEPTEMBER}

19

Going along this old Carlisle road, ... . I perceived the grateful scent of the Dicksonia fern now partly decayed. It reminds me of all up country, with its springy mountain sides and unexhausted vigor. . . . When I wade through by narrow cowpaths, it is as if I had strayed into an ancient and decayed herb garden. Nature perfumes her garments with this essence now especially. . . The very scent of it, if you have a decayed frond in your chamber, will take you far up country in a twinkling. You would think you had gone after the cows there, or were lost on the mountains.

THoreav: Autumn.

\section{0}

We heard the sigh of the first autumnal wind, and even the water had acquired a grayer hue. The sumach, grape, and maple were already changed, and the milkweed had turned to a deep, rich yellow. In all woods the leaves were fast ripening for their fall; for their full veins and lively gloss mark the ripe leaf and not the sered one of the poets; and we knew that the maples, stripped of their leaves among the earliest, would soon stand like a wreath of smoke along the edge of the meadow.

Thoreav: A Week on the Concord and Merrimack Rivers. 


\section{SEPTEMBER}

19

Shagbarks and Pignuts ripen. 


\section{SEPTEMBER}

\section{I}

Beautiful yet for me this autumn day

Melts on its sunset hills; and, far away,

For me the ocean lifts its solemn psalm,

To me the pine-woods whisper ; and for me

Yon river, winding through its vales of calm,

By greenest banks, with asters purple-starred,

And gentian bloom and goldenrod made gay,

Flows down in silent gladness to the sea,

Like a pure spirit to its great reward!

Whittier: The Prisoners of Naples.

These almost invisible nets, as it were, are spread for us, and whole coveys of desmodium and bidens seeds steal transportation out of us. I have found myself often covered, as it were, with an imbricated coat of the brown desmodium seeds or a bristling chevaux-de-frise of beggar ticks, and had to spend a quarter of an hour or more picking them off in some convenient spot; and so they get just what they wanted, deposited in another place. How surely the desmodium growing on some rough cliff-side, or the bidens on the edge of a pool, prophesy the coming of the trareler, brute or human, that will transport their seeds on his coat!

ThoreaU: Autumn. 
SEPTEMBER

2 I

22 


\section{SEPTEMBER}

\section{3}

One looks upon the woods with a new interest when he suspects they hold a colony of bees. What a pleasing secret it is - a tree with a heart of comb honey, a decayed oak or maple with a bit of Sicily or Mount Hymettus stowed away in its trunk or branches; secret chambers where lies hidden the wealth of ten thousand little freebooters, great nuggets and wedges of precious ore gathered with risk and labor from every field and wood about !

Burroughs: Pepacton.

\section{4}

White birches have fairly begun to yellow, and blackberry vines here and there in sunny places look like a streak of blood in the grass. I sit on the hillside at Miles's Swamp. A woodbine, investing the leading stem of an elm in the swamp quite to its top, is seen as an erect, slender red column through the thin and yellowing foliage of the elm.

Thoreav: Autumn. 
SEPTEMBER

23

24 


\section{SEPTEMBER}

25

By the twenty-fifth of September, the red maples generally are beginning to be ripe. Some large ones have been conspicuously changing for a week, and some single trees are now very brilliant. I notice a small one, half a mile off across a meadow, against the green woodside there, a far brighter red than the blossoms of any tree in summer, and more conspicuous. I have observed this tree for several autumns invariably changing earlier than its fellows, just as one tree ripens its fruit earlier than another. It might serve to mark the season, perhaps.

Thorenu: Autumnal Tints.

\section{6}

The scarlet of the dogwood is the most conspicuous and interesting of the autumnal colors at present. You can now easily detect them at a distance. Every one in the swamps you have overlooked is revealed. The smooth sumach and the mountain ash are a darker, deeper, bloodier red.

Thoreav: Autumn.

How beautiful, when a whole tree is like one great scarlet fruit full of ripe juices, every leaf, from lowest limb to topmost spire, all aglow, especially if you look towards the sun!

Thoreav: Autumnal Tints. 


\section{SEPTEMBER}

25

26 


\section{SEPTEMBER}

\section{7}

I observed the other day that those insects whose ripple I could see from the peak were water bugs. I could detect the progress of a water bug over the smooth surface in almost any part of the pond, for they furrow the water slightly, making a conspicuous ripple, bounded by two diverging lines, but the skaters slide over it without producing a perceptible ripple. In this clear air, and with this glassy surface, the motion of every water bug, here and there amid the skaters, was perceptible.

Thoreav: Autumn.

\section{8}

The pearly everlasting is an interesting white at present. Though the stem and leaves are still green, it is dry and unwithering like an artificial flower; its white flexuous stem and branches, too, like wire wound with cotton. Neither is there any scent to betray it. Its amaranthine quality is instead of high color. Its very brown centre now affects me as a fresh and original color. It monopolizes small circles in the midst of sweet fern, perchance, on a dry hillside.

Thoreav: Autumn. 
SEPTEMBER

27

28 


\section{SEPTEMBER}

29

I see many myrtle-birds now about the house, this forenoon, on the advent of cooler weather. They keep flying up against the house and the window, and fluttering there as if they would come in, or alight on the woodpile or the pump. They would commonly be mistaken for sparrows, but show more white when they fly, beside the yellow on the rump and sides of breast, seen near to, and two white bars on the wings; chubby birds.

Troreau: Autumn.

\section{0}

Standing on the railroad, I look across the pond to Pine Hill, where the outside trees, and the shrubs scattered generally through the wood, glow yellow and scarlet through the green, like fires just kindled at the base of the trees, a general conflagration just fairly under way, soon to envelop every tree. The hillside forest is all aglow along its edge, and in all its cracks and fissures, and soon the flames will leap upwards to the tops of the tallest trees.

Thoreau: Autumn. 


\section{SEPTEMBER}

29

Slate-colored Junco; Myrtle Warbler. 


\section{OCTOBER}

Now too, the first of October, or later, the elms are at the height of their autumnal beauty, great brownish yellow masses, warm from their September oven, hanging over the highway. Their leaves are perfectly ripe. I wonder if there is any answering ripeness in the lives of the men who live beneath them. As I look down our street, which is lined with them, they remind me both by their form and color of yellowing sheaves of grain, as if the harrest had indeed come to the village itself, and we might expect to find some maturity and flavor in the thoughts of the villagers at last.

Thoreau: Autumnal Tints.

The intense brilliancy of the red-ripe maples scattered here and there in the midst of the green oaks and hickories on the hilly shore of Walden is quite charming. They are unexpectedly and incredibly brilliant, especially on the western shore and close to the water's edge, where, alternating with yellow birches and poplars and green oaks, they remind me of a line of soldiers, redcoats and riflemen in green mixed together.

Thoreav: Autumn. 


\section{OCTOBER}

White-throated Sparrow.

Brown Creeper; Golden-crowned Kinglet. 


\section{OCTOBER}

A large flock of grackles amid the willows by the river-side, or chiefly concealed low in the button-bushes beneath them, though quite near me. There they keep up their spluttering notes, though somewhat less loud, I fancy, than in spring. These are the first I have seen, and now for some time I think the redwings have been gone. These are the first arrivers from the north, where they breed.

Thoreav: Autumn.

\section{4}

Succory still, with its cool blue, here and there, and Hieracium Canadense still quite fresh, with its pretty, broad, strap-shaped rays, broadest at the end, alternately long and short, with five very regular sharp teeth in the end of each. The scarlet leaves and stem of the rhexia, some time out of flower, make almost as bright a patch in the meadow now as the flowers did. Its seed vessels are perfect little cream pitchers of graceful form.

THoreav: Autumn. 


\section{OCTOBER}

3

Rusty Blackbird; Yellow Palm Warbler.

4 


\section{OCTOBER}

5

The witch-hazel loves a hillside with or without wood or shrubs. It is always pleasant to come upon it unexpectedly as you are threading the woods in such places. Methinks I attribute to it some elfish quality apart from its fame. I love to behold its gray speckled stems. The leaf first green, then yellow for a short season; then, when it touches the ground, tawny leather-color.

Troreau: Autumn.

The jays scream on the right and left as we go by, flitting and screaming from pine to pine.

Thoreav: Days and Nights in Concord.

\section{6}

The scarlet maples burn, the golden leaves of poplar and birch shine through the misty veil, and the deep purple of the ash glows as if it held a smouldering fire that the first breeze might fan into a flame, and through all this luminous leafage one may trace branch and twig as a wick in a candle flame. Only the evergreens are dark as when they bear their steadfast green in the desolation of winter, and only they brood shadows.

Robisson: In New England Fields and Woods. 


\section{OCTOBER}

$$
5
$$

Witch-Hazel.

6 


\section{OCTOBER}

\section{7}

In the huckleberry pasture, by the fence of old barn boards, I notice many little pale-brown, domeshaped puffballs puckered to a centre beneath. When you pincl them, a smoke-like, brown, snuffcolored dust rises from the orifice at their top, just like smoke from a chimney. . . . They are low Oriental domes or mosques, sometimes crowded together in nests, like a collection of humble cottages on the moor; for there is suggested some humble hearth beneath, from which this smoke comes up, as it were the homes of slugs and crickets.

Thoreav: Autumn.

\section{8}

The nights now are very still, for there is hardly any noise of birds or insects. The whip-poor-will is not heard, nor the mosquito; only the occasional lisping of some sparrow. As I go through the woods, I perceive a sweet dry scent from the underwoods like that of the fragrant life-everlasting. I suppose it is that. I frequently see a light on the ground within thick and dark woods, where all around is in shadow, and hasten forward expecting to find some decayed and phosphorescent stump, but find it to be some clear moonlight that falls through a crevice in the leaves.

THOREAU: Autumn. 
OCTOBER

7

8 


\section{OCTOBER}

\section{9}

Bradford Torrey, 1843.

The ash her purple drops forgivingly

And sadly, breaking not the general hush;

The maple-swamps glow like a sunset sea,

Each leaf a ripple with its separate flush;

All round the wood's edge creeps the skirting

blaze

Of bushes low, as when, on cloudy days,

Ere the rain fall, the cautious farmer burns his brush.

LOWELL: An Indian-Summer Reverie.

\section{IO}

Some white oak acorns in the path by a woodside I found to be unexpectedly sweet and palatable, the bitterness being scarcely perceptible. To my taste they are quite as good as chestnuts. No wonder the first men lived on acorns. Such as these are no mean food, as they are represented to be. Their sweetuess is like the sweetness of bread. The whole world is sweeter to me for having discovered such palatableness in this neglected nut. I am related again to the first men. What can be handsomer, wear better to the eye, than the color of the acorn, like the leaves on which it falls, polished or varnished.

Thoreav: Autumn. 


\section{OCTOBER}

9

Hermit Thrush.

10

Ruby-crowned Kinglet. 


\section{OCTOBER}

\section{I}

In such weather the woodland air is laden with the light burden of odor, the faintly pungent aroma of the ripened leaves, more subtle than the scent of pine or fir, yet as apparent to the nostrils, as delightful and more rare, for in the round of the year its days are few, while in summer sunshine and winter wind, in springtime shower and autumnal frost, pine, spruce, balsam, hemlock, and cedars distill their perfume and lavish it on the breeze or gale of every season.

Robinson: In New England Fields and Woods.

\section{2}

The chestnut leaves already rustle with a great noise as you walk through the woods, lying light, firm, and crisp. Now the chestnuts are rattling out. The burrs are gaping and showing the plump nuts. They fill the ruts in the road and are abundant amid the fallen leaves in the midst of the wood. The jays scream and the red squirrels scold while you are clubbing and shaking the trees. Now it is true autumn, and all things are crisp and ripe.

Thoreat: Autumn. 


\section{OCTOBER}

II

12 


\section{OCTOBER}

\section{3}

The birch, most shy and ladylike of trees, Her poverty, as best she may, retrieves,

And hints at her foregone gentilities With some saved relics of her wealth of leaves;

The swamp-oak, with his royal purple on,

Glares red as blood across the sinking sun, As one who proudlier to a falling fortune cleaves.

LowELL: An Indian-Summer Reverie.

\section{4}

For beautiful variety no crop can be compared with this. Here is not merely the plain yellow of grains, but nearly all the colors that we know, the brightest blue not excepted: the early blushing maple, the poison-sumach blazing its sins as scarlet, the mulberry ash, the rich chrome yellow of the poplars, the brilliant red huckleberry, with which the hills' backs are painted, like those of sheep. The frost touches them, and, with the slightest breath of returning day or jarring of earth's axle, see in what showers they come floating down! The ground is all party-colored with them.

Thoreau: Autumnal Tints. 


\section{OCTOBER}

I3

14 


\section{OCTOBER}

\section{5}

As I pushed up the river past Hildreth's, I saw a blue heron arise from the shore, and disappear round a bend in front; the greatest of the bitterns, with heavy undulating wings low over the water, seen against the woods, just disappearing round a bend in front; with a great slate-colored expanse of wing, suited to the shadows of the stream, a tempered blue as of the sky and dark water commingled.

Thoreau: Autumn.

\section{I6}

The witch-hazel here is in full blossom on this magical hillside, while its broad yellow leaves are falling. Some bushes are completely bare of leaves, and leather-colored they strew the ground. It is an extremely interesting plant, October and November child, and yet reminds me of the very earliest spring. Its blossoms smell like the spring, like the willow catkins. By their color as well as fragrance they belong to the saffron dawn of the year, suggesting amid all these signs of autumn, falling leaves, and frost, that the life of nature by which she eternally flourishes is untouched.

Thoreau: Autumn. 


\section{OCTOBER}

I 5

16 


\section{OCTOBER}

\section{7}

There is hardly a more striking feature in the landscape nowadays than the red patches of blueberry and whortleberry bushes, as seen on a sloping hillside, like islands among the grass, with trees growing in them; or crowning the summit of a bare, brown hill with their somewhat russet liveliness; or circling round the base of an earthimbedded rock. At a distance, this hue, clothing spots and patches of the earth, looks more like a picture than anything else, - yet such a picture as I never saw painted.

Hawthorne: American Note-Books.

\section{8}

The leaves of late red maples, still bright, strew the earth, often crimson-spotted on a yellow ground, like some wild apples, - though they preserve these bright colors on the ground but a day or two, especially if it rains. On causeways I go by trees here and there all bare and smoke-like, having lost their brilliant clothing; but there it lies, nearly as bright as ever on the ground on one side, and making nearly as regular a figure as lately on the tree. . . . A queen might be proud to walk where these gallant trees have spread their bright cloaks in the mud.

Thoreav: Autumnal Tints. 


\section{OCTOBER}

17

I 8 


\section{OCTOBER}

19

I hear the alarum of a small red squirrel, and see him running by fits and starts along a chestnut bough toward me.... He chirrups and vibrates his tail, holds himself in, and scratches along a foot as if it was a mile... He gets down the trunk at last upon a projecting knob, head downward, within a rod of you, and chirrups and chatters louder than ever, trying to work himself into a fright. The hind part of his body is urging the forward part along, snapping the tail over it like a whiplash, but the fore part mostly clings fast to the bark with desperate energy.

Thorkau: Autumn.

\section{0}

Now and for some weeks is the time for flocks of sparrows of various kinds flitting from bush to bush and tree to tree (and both bushes and trees are thinly leaved or bare), and from one seared meadow to another. They are mingled together and their notes even, being faint, are, as well as their colors and motions, much alike. The sparrow youth are on the wing. They are still further concealed by their resemblance in color to the gray twigs and stems which are now beginning to be bare.

Thoreav: Autumn. 
OC'TOBER

19

20 


\section{OC'TOBER}

\section{I}

To-day, October 21st, I found the air in the bushy fields and lanes under the woods loaded with the perfume of the witch-hazel, - a sweetish, sickening odor. With the blooming of this bush, Nature says, "Positively the last." It is a kind of birth in death, of spring in fall, that impresses one as a little uncanny. All trees and shrubs form their flower-buds in the fall, and keep the secret till spring. How comes the witch-hazel to be the one exception, and to celebrate its floral nuptials on the funeral day of its foliage?

Burrovgrs: Winter Sunshine.

\section{2}

The air this morning is full of bluebirds, and again it is spring. There are many things to indicate the renewing of spring at this season, the blossoming of spring flowers, not to mention the witch-hazel, the notes of spring birds, the springing of grain and grass and other plants.

\section{Thoreav: Autumn.}

The jay is the bird of October. I have seen it repeatedly flitting amid the bright leaves, of a different color from them all, and equally bright, taking its flight from grove to grove. It, too, with its bright color, stands for some ripeness in the bird harvest.

Thoreav: Autumn. 
OCTOBER

21

22 


\section{OCTOBER}

\section{3}

The wasps came by thousands to my lodge in October, as to winter quarters, and settled on my windows within and on the walls overhead, sometimes deterring visitors from entering. Each morning, when they were numbed with cold, I swept some of them out, but I did not trouble myself much to get rid of them; I even felt complimented by their regarding my house as a desirable shelter. They never molested me seriously, though they bedded with me; and they gradually disappeared, into what crevices I do not know, avoiding winter and unspeakable cold.

Troreau: Walden.

\section{4}

With Blake up Assabet. Saw in the pool at the Hemlocks what I at first thought was a brighter leaf moved by the zephyr on the surface of the smooth, dark water, but it was a splendid male summer duck, which allowed us to approach within seven or eight rods. It was sailing up close to the shore, and then rose and flew up the curving stream. It was a perfect floating gem, and Blake, who had never seen the like, was greatly surprised, not knowing that so splendid a bird was found in this part of the world.

Troreav: Autumn. 


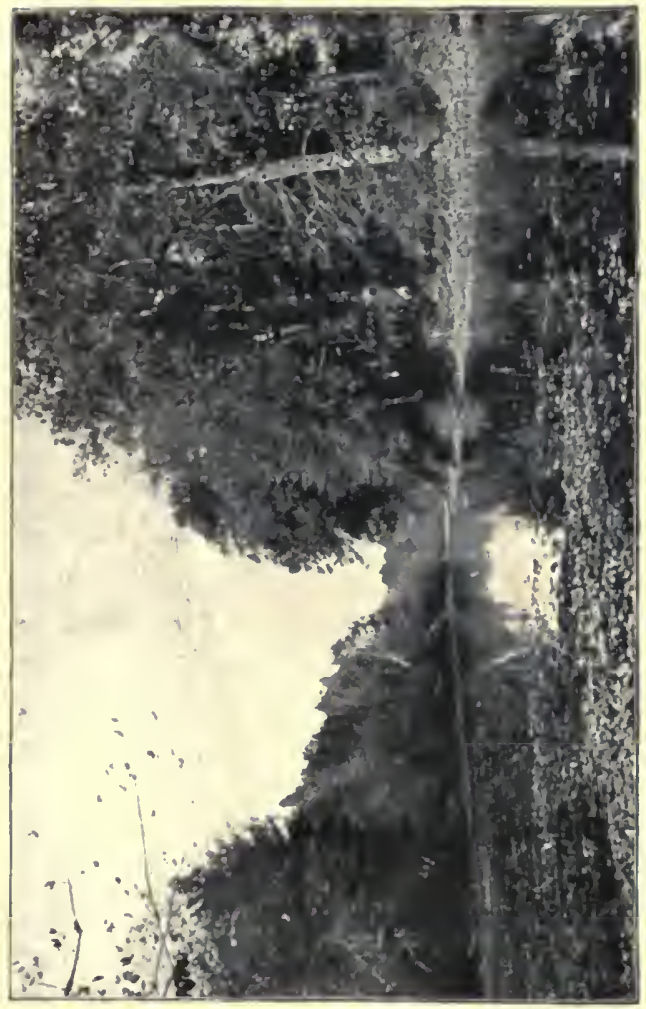





\section{OCTOBER}

23

24

Fox Sparrow. 


\section{OCTOBER}

\section{5}

Invade some butternut or hickory-nut grove on a frosty October morning, and hear the red squirrel beat the "juba" on a horizontal branch. It is a most lively jig, what the boys call a "regular break-down," interspersed with squeals and snickers and derisive laughter. The most noticeable peculiarity about the vocal part of it is the fact that it is a kind of duet. In other words, by some ventriloquial tricks, he appears to accompany himself, as if his voice split up, a part forming a low guttural sound, and a part a shrill nasal sound.

Burroughs: Winter Sunshine.

\section{6}

I slowly discover that this is a gossamer day. I first see the fine lines stretching from one weed, or grass-stem or rush, to another, sometimes seven or eight feet distant horizontally, and only four or five inches above the water. When I look further, I find that they are everywhere and on everything, sometimes forming conspicuous fine white gossamer webs on the heads of grasses. They are so abundant that they seem to have been suddenly produced in the atmosphere by some chemistry, spun out of air, I know not for what purpose.

Thoreav: Autumn. 


\section{OCTOBER}

25

26 


\section{OCTOBER}

\section{7}

But it requires a particular alertness if not devotion to these phenomena, to appreciate the widespread, but late and unexpected glory of the scarlet oaks. I do not speak here of the small trees and shrubs, which are commonly observed, and which are now withered, but of the large trees. Most go in and shut their doors, thinking that bleak and colorless November has already come, when some of the most brilliant and memorable colors are not yet lit.

Thoreav: Autumnal Tints.

\section{8}

It was late in mild October, and the long autumnal rain

Had left the summer harvest-fields all green with grass again ;

The first sharp frosts had fallen, leaving all the woodlands gay

With the hues of summer's rainbow, or the meadow-flowers of May.

WhitTIER: The Huskers. 


\section{OCTOBER}

27

28 


\section{OCTOBER}

\section{9}

Going over the large hillside stubble field west of Holden wood, I start up a large flock of shore larks, hear their sveet sveet and sveet sveet sveet, and see their tails dark beneath. They are very wary, and run in the stubble, for the most part invisible, while one or two appear to act the sentinel at some rock, peeping out behind it, perhaps, and give their note of alarm, when away goes the whole flock. Such a flock circled back and forth several times over my head, just like ducks reconnoitring before they alight. If you look with a glass, you are surprised to see how alert the spies are. These larks have dusky bills and legs.

Thoreav: Autumn.

To appreciate the wild and sharp flavors of these October fruits, it is necessary that you be breathing the sharp October or November air. The out-door air and exercise which the walker gets give a different tone to his palate, and he craves a fruit which the sedentary would call harsh and crabbed. They must be eaten in the fields, when your system is all aglow with exercise, when the frosty weather nips your fingers, the wind rattles the bare boughs or rustles the few remaining leaves, and the jay is heard screaming around. What is sour in the house a bracing walk makes sweet. Some of these apples might be labeled, "To be eaten in the wind."

THOREAU: Wild Apples. 
OCTOBER

29

30 


\section{OCTOBER}

\section{1}

Frank Bolles, 1856.

I see a pretty large flock of tree sparrows, very lively and tame, pursuing each other and drifting along a bushy fence and ditch like driving snow. Two pursuing each other would curl upward like a breaker in the air, and drop into the hedge again.

Thoreau: Autumn.

There is something witch-like in the appearance of the witch-hazel, which blossoms late in October and in November, with its irregular and angular spray and petals like furies' hair, or small ribbon streamers. Its blossoming, too, at this irregular period, when other shrubs have lost their leaves, as well as blossoms, looks like witches' craft. Certainly it blooms in no garden of man's. There is a whole fairy-land on the hillside where it grows.

THoreav: A Week on the Concord and Merrimack Rivers. 


\section{OCTOBER}

$$
3 \text { I }
$$

Tree Sparrow. 


\section{NOVEMBER}

The other day I could hardly find a well-known spring, and even suspected that it had dried up, for it was completely concealed by freshly fallen leaves; and when I swept them aside and revealed it, it was like striking the earth, with Aaron's rod, for a new spring. Wet grounds about the edges of swamps look dry with them. At one swamp, where I was surveying, thinking to step on a leafy shore from a rail, I got into the water more than a foot deep.

Thoreav: Autumnal Tints.

\section{2}

Several crows are walking about a newly sowed wheatfield we pass through, and we pause to note their graceful movements and glossy coats. I have seen no bird walk the ground with just the same air the crow does. It is not exactly pride; there is no strut or swagger in it, though perhaps just a little condescension; it is the contented, complaisant, and self-possessed gait of a lord over his domains. All these acres are mine, he says, and all these crops; men plow and sow for me, and I stay here or go there, and find life sweet and good wherever I am.

Burrovgrs: Pepacton. 


\section{NOVEMBER}

1

2 


\section{NOVEMBER}

Looking across this woodland valley, a quarter of a mile wide, how rich those scarlet oaks embosomed in pines, their bright red branches intimately intermingled with them! The pine-boughs are the green calyx to their red petals. Or, as we go along a road in the woods, the sun, striking endwise through it, and lighting up the red tents of the oaks, which on each side are mingled with the liquid green of the pines, makes a very gorgeous scene. Indeed, without the evergreens for contrast, the autumnal tints would lose much of their effect.

Thoreau: Autumnal Tints.

\section{4}

Occasionally, when threading the roods in the fall, you will hear a.sound as if some one had broken a twig, and, looking up, see a jay pecking at an acorn, or you will see a flock of them at once about it, in the top of an oak, and hear them break them off. They then fly to a suitable limb, and placing the acorn under one foot, hammer away at it busily, making a sound like a woodpecker's tapping, looking round from time to time to see if any foe is approaching, and soon reach the meat, and nibble at it, holding up their heads to swallow, while they hold the remainder very firmly with their claws.

Thoreav: The Succession of Forest Trees. 
NOVEMBER

3

4 
The oaks are now beginning to look sere, and their leaves have withered borders. It is pleasant to notice the wide circle of greener grass beneath the circumference of an overshadowing oak. Passing an orchard, one hears an uneasy rustling in the trees, and not as if they were struggling with the wind. Scattered about are barrels to contain the gathered apples; and perhaps a great heap of golden or scarlet apples is collected in one place.

HaWthomse: American Note-Books.

\section{6}

In Weston's field in springy land on the edge of a swamp I counted thirty-three or four of those large silvery brown cocoons within a rod or two, and probably there are many more; about a foot from the ground, commonly on the main stem, though sometimes on a branch close to the stem, of the alder, sweet fern, brake, etc. The largest are four inches long by two and one half wide, bagshaped and wrinkled, and partly concealed by dry leaves, alder, fern, etc., attached, as if sprinkled over them.

Thokeav: Winter. 
NOVEMBER

5

6 


\section{NOVEMBER}

\section{7}

The beech leaves have all fallen except some about the lower part of the trees, and they make a fine thick bed on the ground. They are very beautiful, fine and perfect leaves, unspotted, not eaten by insects, of a handsome, clear leather color, like a book bound in calf, crisp and elastic. They cover the ground so perfectly and cleanly as to tempt you to recline on it, and admire the beauty of the smooth boles from that position, covered with lichens of various colors, green, etc.

Thoreau: Autumn.

\section{8}

See this great fleet of scattered leaf-boats which we paddle amid, in this smooth river-bay, each one curled up on every side by the sun's skill, each nerve a stiff spruce-knee, - like boats of hide, and of all patterns, Charon's boat probably among the rest, and some with lofty prows and poops, like the stately vessels of the ancients, scarcely moving in the sluggish current, - like the great fleets, the dense Chinese cities of boats, with which you mingle on entering some great mart, some New York or Canton, which we are all steadily approaching togetlier.

Tuoneav: Autumnal Tints. 
NOVEMBER

7

8 
9

On the side of the meadow moraine, just north of the boulder field, I see barberry bushes three inches in diameter and ten feet high. What a surprising color this wood has. It splits and splinters very much when I bend it. I cut a cane, and, shaving off the outer bark, find it of imperial yellow, as if painted, - fit for a Chinese mandarin.

Thoreav: Early Spring in Massachusetts.

IO

In a stubble field started up a bevy (about twenty) of quail which went off to some young pitch pines with a whir like a shot, the plump round birds.

Thoreav: Early Spring in Massachusetts.

The muskrat houses appear now, for the most part, to be finished, though some are still rising. They line the river all the way. Some are as big as small haycocks.

Thoreau: Autumn. 
NOVEMBER

9

10 


\section{NOVEMBER}

\section{I}

The eagle is a bird of large ideas; he embraces long distances; the continent is his home. I never look upon one without emotion; I follow him with my eye as long as I can. I think of Canada, of the Great Lakes, of the Rocky Mountains, of the wild and sounding seacoast. The waters are his, and the woods and the inaccessible cliffs. He pierces behind the veil of the storm, and his joy is height and depth and vast spaces.

Burroughs: Pepacton.

\section{2}

As I stood . . . near Flint's Pond, a flock of a dozen chickadees came flitting and singing about me with great ado, a most cheering and enlivening sound, with incessant day-day-day, and a fine wiry strain, between whiles, flitting ever nearer and nearer inquisitively, till the boldest was within five feet of me; then suddenly, their curiosity sated, they flitted by degrees farther away, disappeared, and I heard with regret their retreating day-daydays.

Thoreav: Autumn. 


\section{NOVEMBER}

I I

12 


\section{NOVEMBER}

\section{I3}

All apples are good in November. Those which the farmer leaves out as unsalable and unpalatable to those who frequent the markets are choicest fruit to the walker. But it is remarkable that the wild apple, which I praise as so spirited and racy when eaten in the fields or woods, being brought into the house, has frequently a harsh and crabbed taste. The Saunterer's Apple not even the saunterer can eat in the house. The palate rejects it there, as it does haws and acorns, and demands a tamed one; for there you miss the November air, which is the sauce it is to be eaten with.

Thoreav: Wild Apples.

\section{4}

This afternoon I heard a single cricket singing, chirruping on a bank, the only one I have heard for a long time, like a squirrel, or a little bird, clear and shrill, - as I fancied, like an evening robin singing in this evening of the year. A very fine and poetical strain for such a little singer. I had never before heard the cricket so like a bird. It is a remarkable note, the earth-song.

That delicate, waving, feathery, dry grass which I saw yesterday is to be remembered with the autumn. The dry grasses are not dead for me. A beautiful form has as much life at one season as at another.

ThoreaU: Autumn. 


\section{NOVEMBER}

13

14 


\section{NOVEMBER}

15

The rare whistle of a bluebird - a skyward and vanishing sound, lost like the bird's own color in the soft autumnal blue - affects us as a momentary revisitation of spring.

Edith M. Thomas: The Round Year.

The partridges go off with a whir, and then sail a long way, level and low, through the woods with that impetus they have got, displaying their neat forms perfectly.

Thoreav: Autumn.

\section{I6}

By the middle of November the wild apples have lost some of their brilliancy, and have chiefly fallen. A great part are decayed on the ground, and the sound ones are more palatable than before. The note of the chickadee sounds now more distinct, as you wander amid the old trees, and the autumnal dandelion is half closed and tearful. But still, if you are a skillful gleaner, you may get many a pocketful even of grafted fruit, long after apples are supposed to be gone out-of-doors.

Thoreav: Wild Apples. 


\section{NOVEMBER}

15

16 


\section{NOVEMBER}

\section{I7}

The sonorous, quavering sounds of the geese are the voice of the cloudy air, a sound that comes from directly between us and the sky, an aerial sound, and yet so distinct, heavy, and sonorous; a clanking chain drawn through the heavy air. I saw through my window some children looking up, and pointing their tiny bows into the heavens, and I knew at once that the geese were in the air. It is always an exciting event. The children, instinctively aware of its importance, rushed into the house to tell their parents. Those travelers are revealed to you by the upward-turned gaze of men.

Thoreav: Autumn.

\section{8}

Asa Grax, 1810.

This swamp [the spruce swamp in Conant's Grove] contains beautiful specimens of the sidesaddle flower, Sarracenia purpurea, better called pitcher-plant. The leaves ray out around the dry scape and flower, which still remain, resting on rich uneven beds of a coarse reddish moss, through which the small-flowered andromeda puts up, presenting altogether a most rich and luxuriant appearance to the eye. Thongh the moss is comparatively dry, I cannot walk without upsetting the numerous pitchers, which are now full of water, and so wetting my feet.

Thoreav: Autumn. 
NOVEMBER

I 7

18 
Ascending a little knoll covered with sweet fern, the sun appearing but little above the sweet fern, its light was reflected from a dense mass of the bare, downy twigs of this plant in a surprising manner which would not be believed, if described. It was quite like the sunlight reflected from grass and weeds covered with hoar frost. Yet in an ordinary light, these are but dark or dusky-looking with scarcely a noticeable downiness. But as I saw them, there was a perfect halo of light resting on the knoll. . . . This is one of the hundred silvery lights of November.

ThoreaU: Autumn.

I see in the path some rank thimble-berry shoots covered very thickly with their peculiar hoary bloom. It is only rubbed off in a few places down to the purple skin, by some passing hunter, perchance. It is a very singular and delicate outer coat surely for a plant to wear. I find that I can write my name on it with a pointed stick very distinctly, each stroke, however fine, going down to the purple. It is a new kind of enameled card. What is this bloom and what purpose does it serve? Is there anything analogous in animated nature?

Thoreav: Autumn. 


\section{NOVEMBER}

19

20 


\section{NOVEMBER}

\section{I}

With startling suddenness out of the monotony of lifeless color in an eddying flurry of dead leaves, fanned to erratic flight by his wing-beats, the ruffed grouse bursts into view, in full flight with the first strokes of his thundering pinions, and you have a brief vision of untamed nature as it was in the old days.

Rosrssox: In New England Fields and Woods.

In the afternoon I met Flood, who endeavored to draw my attention to a flock of geese in the mizzling air, but encountering me he lost sight of them, while I at length, looking that way, discov: ered them, though he could not.

Thoreau: Autumn.

\section{2}

Birds generally wear the russet dress of nature at this season. They have their fall, no less than the plants. The bright tints depart from their foliage or feathers, and they flit past like withered leaves in rustling flocks. The sparrow is a withered leaf. Perchance I heard the last cricket of the season yesterday, - they chirp here and there at longer and longer intervals till the snow quenches their song, - and the last striped squirrel, too, perchance, yesterday. They then do not go into winter quarters till the ground is covered with snow.

Thoreav: Autumn. 


\section{NOVEMBER}

2 I

22 


\section{NOVEMBER}

\section{3}

Again I am struck by the singularly wholesome colors of the withered oak leaves, especially the shrub oak, so thick and firm and unworn, without speck, clear reddish-brown, sometimes paler or yellowish-brown, the whitish under sides contrasting with the upper in a very cheerful manner, as if the tree or shrub rejoiced at the advent of winter. It exhibits the fashionable colors of the winter on the two sides of its leaves. It sets the fashions; colors good for bare ground or for snow, grateful to the eyes of rabbits and partridges. This is the extent of its gaudiness, red-brown and misty-white, and yet it is gay.

Thoreav: Autumn.

\section{4}

Who knows not Silver-Rod, the lovely and reverend old age of Golden-Rod,- else Golden-Rod beatified and sainted, looking moonlit and misty even in the sunshine! In this soft, canescent afterbloom beginning at the apex of the flower cluster and gradually spreading downward, the eye finds an agreeable relief from the recent dazzle of yellow splendor. I almost forget that the herb is not literally in bloom, that it is no longer ministered to by sunshine and dew.

Edith M. Thomas: The Round Year. 
NOVEMBER

23

24 


\section{NOVEMBER}

\section{5}

The forest floor is covered with a thick coat of moist brown leaves, but what is that perennial and spring-like verdure that clothes the rocks, of small green plumes pointing various ways? It is the cheerful community of the polypody. It survives at least as the type of vegetation, to remind us of the spring which shall not fail. These are the green pastures where I browse now. Why is not this form copied by our sculptors instead of the foreign acanthus leaves and bays? How fit for a tuft about the base of a column!

Thoreav: Autumn.

\section{6}

The muskrats are more active since the cold weather. I see more of them about the river now, swimming across back and forth, and diving in the middle where I lose them. They dive off the round-backed black mossy stones, which when small and slightly exposed look much like themselves. In swimming, show commonly three parts, with water between. One, sitting in the sun, as if for warmth, on the opposite shore to me, looks quite reddish-brown. They avail themselves of the edge, of the ice now found along the sides of the river, to feed on.

Thoreau: Autumn. 


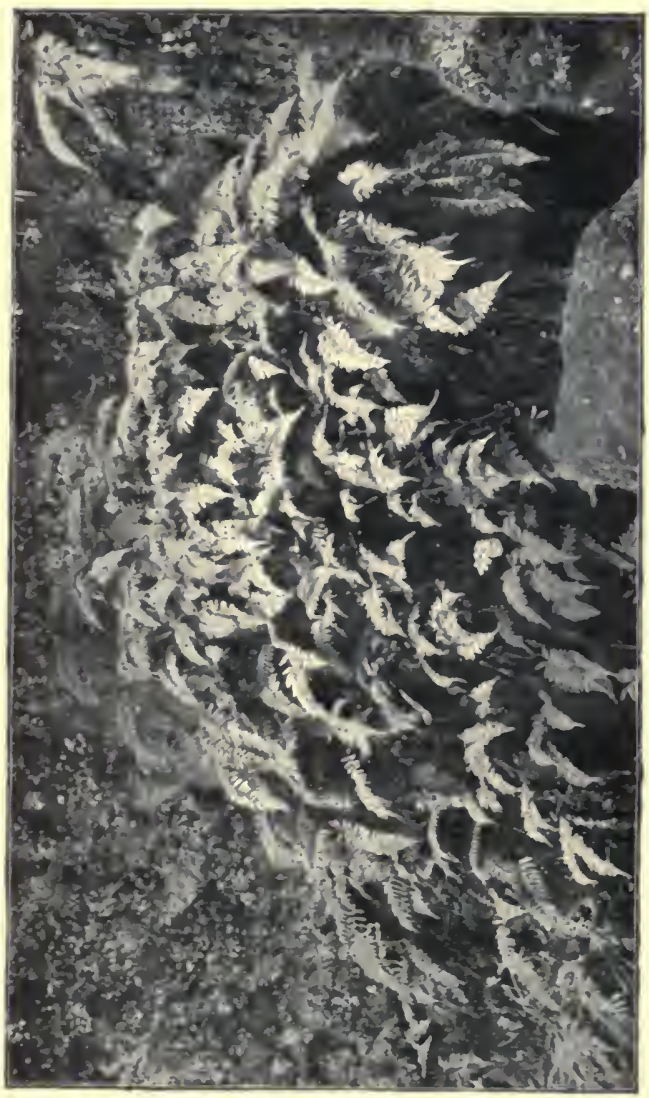


s 
NOVEMBER

25

26 


\section{NOVEMBER}

\section{7}

With mingled sound of horns and bells,

A far-heard clang, the wild geese fly,

Storm-sent, from Arctic moors and fells,

Like a great arrow through the sky,

Two dusky lines converged in one,

Chasing the southward-flying sun;

While the brave snowbird and the hardy jay

Call to them from the pines, as if to bid them stay.

Whittier: The Last Walk in Autumn.

\section{8}

I hear a red squirrel barking at me amid the pine and oak tops, and now I see him coursing from tree to tree. How securely he travels there fifty feet from the ground, leaping from the slender, bending twig of one tree across an interval of three or four feet, and catching at the nearest twig of the next, which so bends under him that it is hard at first to get up. His traveling is a succession of leaps in the air at that height, without wings! And yet he gets along about as rapidly as on the ground.

Thoreav: Autumn. 


\section{NOVEMBER}

27

28 


\section{NOVEMBER}

\section{9}

Everything stands silent and expectant. If I listen, I hear only the note of a chickadee, our most common bird at present, most identified with our forests, or perchance the scream of a jay, or from the solemn depths of the woods I hear tolling far away the knell of one departed. Thought rushes in to fill the vacuum. As you walk, however, the partridge bursts away from the foot of a shrub oak, like its own dry fruit; immortal bird! This sound still startles us. The silent, dry, almost leafless, certainly fruitless woods, you wonder what cheer that bird can find in them.

Thoreau: Autumn.

\section{0}

The dear wholesome color of shrub-oak leaves, so clean and firm, not decaying, but which have put on a kind of immortality, not wrinkled and thin like the white-oak leaves, but full-veined and plump as nearer earth. Well-tanned leather on the one side, sun-tanned, color of colors, color of the cow and the deer, silver-downy beneath, turned toward the late bleached and russet fields. . . . I love and could embrace the shrub oak, with its scanty garment of leaves rising above the snow, lowly whispering to me, akin to winter thoughts, and sunsets, to all virtue; coverts which the hare and the partridge seek, and I too seek.

Thoreav: Autumn. 


\section{NOVEMBER}

29

30 


\section{DECEMBER}

Ah, the beautiful tree, the hemlock, with its green canopy, under which little grows, not exciting the cupidity of the carpenter, whose use most men have not discovered. I know of some memorable ones worth walking many miles to see. These little cheerful hemlocks, the lisp of chickadees seems to come from them now, each standing with its foot on the rery edge of the stream, reaching sometimes part way over its channel, and here and there one has lightly stepped across. These evergreens are plainly as much for shelter for the birds as for anything else.

Thoreav: Autumn.

The cawing of the crow resounds among the woods. A sentinel is aware of your approach a great way off, and gives the alarm to his comrades loudly and eagerly,-Caw, caw, caw! Immediately the whole conclave replies, and you behold them rising above the trees, flapping darkly, and winging their way to deeper solitudes. Sometimes, however, they remain till you come near enough to discern their sable gravity of aspect, each occupying a separate bough, or perhaps the blasted tip-top of a pine. As you approach, one after another, with loud cawing, flaps his wings and throws himself upon the air.

Hawthorne: American Note-Books. 


\section{DECEMBER}

I

2 


\section{DECEMBER}

\section{3}

Saw a shrike pecking to pieces a small bird, apparently a snowbird. At length he took him up in his bill, almost half as big as himself, and flew slowly off with his prey dangling from his beak. I find that I had not associated such actions with my idea of birds. It was not bird-like.

TroRenu: Winter.

A flock of snow buntings pass high above us, uttering their contented twitter, and their white forms seen against the intense blue give the impression of large snowflakes drifting across the sky.

Burroughs: Pepacton.

\section{4}

The brook here is full of cat-tails, Typha latifolia, reed-mace. I found on pulling open, or breaking in my hand, as one would break bread, the still perfect spikes of this fine reed, that the flowers were red or crimson at their base where united to the stem. When I rubbed off what was at first but a thimbleful of these dry flowerets, they suddenly took in air and flashed up like powder, expanding like feathers or foam, filling and overflowing my hand, to which they imparted a sensation of warmth quite remarkable.

Troreav: Winter. 


\section{DECEMBER}

3

4 


\section{DECEMBER}

\section{5}

All things considered, no evergreen can be equal to a summer-green, on which we see the leaves budding, unfolding, ripening, and falling, - a "worlde whiche neweth everie daie." What would winter be worth without the naked branches of maples and elms, beeches and oaks? We speak of them sadly :

"Bare ruined choirs, where late the sweet birds sang."

But the sadness is of a pleasing sort, that could ill be spared by any who know the pleasures of sentiment and sober reflection.

TorreY: The Foot-Path Way.

\section{6}

The deciduous trees are inconstant friends that fail us when adverse winds do blow; but the pine and all its tribe look winter cheerily in the face, tossing the snow, masquerading in his arctic livery, in fact holding high carnival from fall to spring. The Norseman of the woods, lofty and aspiring, tree without bluster or noise, that sifts the howling storm into a fine spray of sound; symmetrical tree, tapering, columnar, shaped as in a lathe, the preordained mast of ships, the mother of colossal timbers; centralized, towering, patriarchal, coming down from the foreworld, counting centuries in thy rings and outlasting empires in thy decay.

Burrovgrs: Signs and Seasons. 


\section{DECEMBER}

5

б 


\section{DECEMBER}

\section{7}

I picked up on the bare ice of the river... a furry caterpillar, black at the two ends and redbrown in the middle, rolled into a ball or close ring, like a woodchuck. I pressed it hard between my fingers and found it frozen, put it into my hat, and when $I$ took it out in the evening, it soon began to stir, and at length crawled about, though a portion of it seemed not quite flexible. It took some time for it to thaw. This is the fifth cold day, and it must have been frozen so long.

THoreav: Winter.

\section{8}

In the birches, on the grasses

Stiffly rising through the snow crust,

On the slope of yonder sand-bank

Where the snow has slipped and wasted,

Rest a flock of trustful strangers,

Lisping words of gentle greeting,

Rest and find the sun's rays warming,

Rest and find their food abundant,

Resting, sing of weary journeys

From a Northland cold and distant.

Bolles: The Red-Poll Linnet. 


\section{DECEMBER}

7

8 


\section{DECEMBER}

9

This afternoon I go to the woods down the railroad, seeking the society of some flock of little birds, or some squirrel, but in vain. I only hear the faint lisp of probably a tree sparrow. I go through empty halls, apparently unoccupied by bird or beast. Yet it is cheering to walk there, while the sun is reflected from far through the aisles with a silvery light from the needles of the pine. The contrast of light or sunshine and shade, though the latter is now so thin, is food enough for me.

Thoreau: Autumn.

10

A winter neighbor of mine, in whom I am interested, and who perhaps lends me his support after his kind, is a little red owl, whose retreat is in the heart of an old apple-tree just over the fence. Where he keeps himself in spring and summer, I do not know, but late every fall, and at intervals all winter, his hiding-place is discovered by the jays and nut-hatches, and proclaimed from the treetops for the space of half an hour or so, with all the powers of voice they can command. Four times during one winter they called me out to behold this little ogre feigning sleep in his den, sometimes in one apple-tree, sometimes in another.

Burrovghs: Signs and Seasons. 


\section{DECEMBER}

9

10 


\section{DECEMBER}

I I

Rigid as iron, clean as the atmosphere, hardy as virtue, innocent and sweet as a maiden, is the shrub oak. In proportion as I know and love it, I am natural and sound as a partridge. I felt a positive yearning toward one bush this afternoon. There was a match found for me at last. I fell in love with a shrub oak. Tenacious of its leaves which shrivel not, but retain a certain wintry life in them, firm shields painted in fast colors, a rich brown. The deer-mouse, too, knows the shrub oak, and has its hole in the snow by the shrub oak's stem.

Thoreau: Autumn.

I watch with interest the first tendency towards solidification in a stream of water. Notice how sluggishly the current drags along; how dark and mantling it looks, like some dense liquid slowly cooling off. Large bubbles collect on the surface. Next, fine crystal bayonets and spears are thrust out from the margin, as though they would impale and hold the unwilling current. Dipping reeds and willow whips are soon glazed over, and made the nuclei of small glacial reefs; the web spreads, and the stream is firmly woven under.

Edith M. Thomas: The Round Year. 


\section{DECEMBER}

I I

12 


\section{DECEMBER}

13

Slate-colored snowbirds flit before me in the path, feeding on the seeds, the countless little brown seeds that begin to be scattered over the snow, so much the more obvious to bird and beast. A hundred kinds of indigenous grain are harvested now, broadcast upon the surface of the snow. Thus, at a critical season, these seeds are shaken down on to a clean, white napkin, unmixed with dirt and rubbish, and off this the little pensioners pick them. Their clean table is thus spread a few inches or feet above the ground.

Thoreav: Autumn.

\section{4}

The bravado of the butcher-bird is great, but it is not unlimited. I saw him, one day, shuffling along a branch in a very nervous, unshrikely fashion, and was at a loss to account for his unusual demeanor till I caught sight of a low-flying hawk sweeping over the tree. Every creature, no matter how brave, has some other creature to be afraid of ; otherwise, how would the world get on?

Torrey: Birds in the Bush.

Yesterday [skating] we saw the pink light on the snow within a rod of us. The shadows of the bridges, etc., on the snow were a dark indigo blue.

Thoreav: Winter. 


\section{DECEMBER}

13

14 


\section{DECEMBER}

\section{5}

When some rare northern bird, like the pine grosbeak, is seen thus far south, in the winter, he does not suggest poverty, but dazzles us with his bealty. There is in them a warmth that is akin to the warmth that melts the icicle. Here is no imperfection suggested. The winter with its snow and ice is not an evil to be corrected. It is as it was designed and made to be, for the artist has had leisure to add beauty to use.

Thoreav: Autumn.

The sun ... was melting the ice on the rocks, and the water was purling downwards in dark bubbles exactly like pollywogs.

Thoreav: Winter.

\section{6}

On the wide lawn the snow lay deep,

Ridged o'er with many a drifted heap;

The wind that through the pine-trees sung

The naked elm-boughs tossed and swung;

While, through the window, frosty-starred, Against the sunset purple barred,

We saw the sombre crow flap by,

The hawk's gray fleck along the sky,

The crested blue-jay flitting swift,

The squirrel poising on the drift,

Erect, alert, his broad gray tail

Set to the north wind like a sail.

WhitTiER: Red Riding-Hood. 
DECEMBER

15

16 


\section{DECEMBER}

\section{7}

Johx Greenleaf Whittrer, 1807.

The alder is one of the prettiest trees and shrubs in the winter. It is evidently so full of life, with its conspicuously pretty red catkins dangling from it on all sides. It seems to dread the winter less than other plants. It has a certain heyday and cheery look, less stiff than most, with more of the flexible grace of summer. With those dangling clusters of red catkins which it switches in the face of winter, it brags for all vegetation. It is not daunted by the cold, but still hangs gracefully over the frozen stream.

Thoread: Winter.

\section{8}

Plum-colored masses of berry bushes encroached upon the wide expanse of snow as headlands reach out into a calm sea. Tiny forests of wiry grass reared their heads above the snow. In color they were what is called "sandy." Goldenrod and aster stems, holding aloft dry and brittle suggestions of long-lost flowers; the heads of brunella, looking like chess castles, and of the Indian pipe, upright and pineapple-shaped; and many delicate hairlike stems from which all trace of leaf and flower had departed, broke the evenness of the snow-fields and were beautiful in an unassuming, unconscious, unintentional way.

Bolles: At the North of Bearcamp Water. 
DECEMBER

17

18 


\section{DECEMBER}

Stood within a rod of a downy woodpecker on an apple-tree. . . . It is briskly and incessantly tapping all round the dead limbs, but hardly twice in a place, as if to sound the tree, and so see if it has any worm in it, or perchance to start them. How much he deals with the bark of trees, all his life long tapping and inspecting it. He it is that scatters these fragments of bark and lichens about on the snow at the base of trees. . . . How briskly he glides up or drops himself down a limb, creeping round and round, and hopping from limb to limb, and now flitting with a rippling sound of his wings to another tree.

Thoreau: Winter.

The country is more of a wilderness, more of a wild solitude, in the winter than in the sunmer. The wild comes out. ... The partridge comes to the orchard for buds; the rabbit comes to the garden and lawn; the crows and jays come to the ashheap and corncrib, the snow buntings to the stack and to the barnyard; the sparrows pilfer from the domestic fowls; the pine grosbeak comes down from the north and shears your maples of their buds; the fox prowls about your premises at night; and the red squirrels find your grain in the barn or steal the butternuts from your attic. In fact, winter, like some great calamity, changes the status of most creatures and sets them adrift.

Burrovghs: Sigus and Seasons. 
DECEMBER

19

20 


\section{DECEMBER}

2 I

In winter when there are no flowers, and leaves are rare, even large buds are interesting and somewhat exciting. I go a-budding like a partridge. I am always attracted at this season by the buds of the swamp pink, the poplars, and the sweet gale.

THOREAv: Winter.

Whichever side you walk in the woods the par. tridge bursts away on whirring wings, jarring the snow from the dry leaves and twigs on high, which comes sifting down in the sunbeams like golden dust, for this brave bird is not to be scared by winter.

Thoreav: Walden.

Drink deep, or be careful how you taste this December vintage. The first sip may chill, but a full draught warms and invigorates. . . . The sunbeams are welcome now. They seem like pure electricity, - like friendly and recuperating lightning. Are we led to think electricity abounds only in summer when we see in the storm-clouds, as it were, the veins and ore-beds of it? I imagine it is equally abundant in winter, and more equable and better tempered. Who ever breasted a snowstorm without being excited and exhilarated, as if this meteor had come charged with latent auroræ of the North, as it doubtless has? It is like being pelted with sparks from a battery.

Burrovghs: Winter Sunshine. 


\section{DECEMBER}

2 I

22 


\section{DECEMBER}

23

The hills seen from Fair Haven Pond make a wholly new landscape. Covered with snow and yellowish green or brown pines, and shrub oaks, they look higher and more massive. Their white mantle relates them to the clouds in the horizon and to the sky. Perhaps what is light-colored looks loftier than what is dark.

THoreav: Winter.

Here comes a little flock of titmice plainly to keep me company, with their black caps and throats making them look top-heavy, restlessly hopping along the alders with a sharp, clear, lisping note.

Thoreav: Winter.

\section{4}

To-day, the noise of the woods was twofold: the great wave or surge sound in the treetops as the wind swept through them ; then, the fitful, cautionary, light whisper, the "sh" and " hist," that ran everywhere among the dry leaves. And what is the tragedy of the cast-off honors of the tree, that, as the feet stir the leafy drift, there go forth the syllables, "hor-ror, hor-ror"?

Eогт M. Thomas: From Winter Solstice to Vernal

Equinox. 


\section{DECEMBER}

23

24 


\section{DECEMBER}

\section{5}

It is surprising what things the snow betrays. I had not seen a meadow-mouse all summer, but no sooner does the snow come and spread its mantle over the earth than it is printed with the tracks of countless mice and larger animals. I see where the mouse has dived into a little hole in the snow not larger than my thumb by the side of a weed, and a yard farther reappeared, and so on alternately above and beneath. A snug life it lives. - The crows come nearer to the houses, alight on trees by the roadside, apparently being put to it for food.

Thoreav: Winter.

\section{6}

The snow is dazzling, the sky far and brightly blue, with a radiant mellow haze about the sun, the air most pure and living, and the trodden path rings with a crisp, metallic echo to the foot. The oxen, in exceeding leisure, sway their gross bulk in balanced step, and drag the heavy sled, whose bent wooden runners squeak in answering cadence. They look at you with great, serious eyes, and puff out long eddies of frosty breath. Their nostrils are fringed beneath with rime, and so are their dewlaps and their knees from the moist warmth of the stables.

Whiting: The Saunterer. 


\section{DECEMBER}

25

26 


\section{DECEMBER}

\section{7}

Coming over the side of Fair Haven Hill at sunset, we saw a long, large, dusky cloud in the northwest horizon, apparently just this side of Wachusett, or at least twenty miles off, which was snowing, when all the rest was clear sky. It was a complete snow-cloud. It looked like rain falling at an equal distance, except that the snow fell less directly, and the upper outline of a part of the cloud was more like that of a dusky mist. . . . It was a rare and strange sight, that of a snowstorm twenty miles off, on the verge of a perfectly clear sky. Thus local is all storm, surrounded by serenity and beauty.

Thoreav: Autumn.

\section{8}

Observed the track of a squirrel in the snow under one of the apple-trees on the southeast side of the hill, and looking up saw a red squirrel with a nut or piece of frozen apple (?) in his mouth within six feet, sitting in a constrained position, partly crosswise, on a limb over my head, perfectly still, and looking not at me, but off into the air, evidently expecting to escape my attention by this trick. I stood, and watched and chirruped to him about five minutes, so near, and yet he did not once turn his head to look at me, or move a foot, or wink. The only motion was that of his tail curled over his back in the wind.

Thoreav: Early Spring in Massachusetts. 


\section{DECEMBER}

\section{7}

28 


\section{DECEMBER}

\section{9}

The apples that cling to the trees, the pods that hang to the lowest branches, and the seeds that the various weeds and grasses hold above the deepest snows, alone make it possible for many birds to pass the winter among us.

Burroughs: Signs and Seasons.

You hear the lisping music of chickadees from time to time, and the unrelenting steel-cold scream of a jay, unmelted, that never flows into a song, a sort of wintry trumpet, screaming cold, hard, tense, frozen music like the winter sky itself.

Thoreav: Winter.

\section{0}

Come see the north wind's masonry.

Out of an unseen quarry evermore

Furnished with tile, the fierce artificer

Curves his white bastions with projected roof

Round every windward stake, or tree, or door.

Speeding, the myriad-handed, his wild work

So fanciful, so savage, naught cares he

For number or proportion.

Emersox: The Snowstorm.

Take long walks in stormy weather, or through deep snows in the fields and woods, if you would keep your spirits up. Deal with brute nature. Be cold and hungry and weary.

Thoreav: Winter. 


\section{DECEMBER}

29 


\section{DECEMBER}

\section{$3 I$}

Going along the turnpike I look over to the pitch pines on Moore's hillside, and it strikes me that this pine, take the year round, is the most cheerful tree and most living to look at and have about your house, it is so sunny and full of light. . . . The deciduous trees are apparently dead and the white pine is much darker, but the pitch pine has an ingrained sunniness and is especially valuable for imparting warmth to the landscape at this season.

Thoreav: Early Spring in Massachusetts.

We skate near to where the blackbird, the pewee, and the kingbird hung their nests over the water, and the hornets builded from the maple in the swamp. How many gay, warblers, following the sun, have radiated from this nest of silver-birch and thistledown. On the swamp's outer edge was hung the supermarine village, where no foot penetrated. In this hollow tree the wood duck reared her brood, and slid away each day to forage in yonder fen.

THoreav: Excursions. 
DECEMBER

3 I 


\section{NOTE}

The selections contained in this volume are taken from the following books by the following authors :-

Frank Bolles:

Land of the Lingering Snow.

At the North of Bearcamp Water.

Chocorua's Tenants.

JOHN BURROUGHS:

Wake-Robin.

Winter Sunshine.

Birds and Poets.

Locusts and Wild Honey.

Pepacton.

Signs and Seasons.

Riverby.

RALPH WALDO EMERSON:

Poems.

NATHANIEL HAWTHORNE:

American Note-Books.

Mosses from an Old Manse.

Oliver Wendell Holmes:

Poems.

James Russell Lowell:

Literary Essays, containing My Garden Acquaintance and A Good Word for Winter.

Poems.

Olive Thorne Miller:

Little Brothers of the Air. 
ROWLAND E. RoBINSON:

In New England Fields and Woods.

Herbert Milto. SYlvester:

Homestead Highways.

EDITH M. Thomas:

The Round Year.

Birds and "Birds," in The Atlantic Monthly, vol. 69.

From Winter Solstice to Vernal Equinox, ibid. vol. 73.

Henry Davil' Thoreau:

A Week on the Concord and Merrimack Rivers.

Walden; or, Life in the Woods.

Early Spring in Massachusetts.

Summer.

Autumn.

Winter.

Excursions, contameng Narural History of Massachusetts; A Walk to Wachusett ; A Winter Walk; The Succession of Forest Trees; Walking; Autumnal Tints; Wild Apples; Night and Moonlight; May Days : Days and Nights in Concord.

BRADFORD TORREY :

Birds in the Bush.

A Rambler's Lease.

The Foot-Path Way.

A Florida Sketch-Book.

Charles Goodrich Whiting:

The Saunterer.

John GreenleaF WhitTier:

Poems. 


\section{(Cbe Itiuersioe 㻆resid}

CAMBRIDGR, MASSACHUSETTS, U. S. A. ELECTROTYPED AND PRINTED BY H. O. HOUGHTON AND CO. 



UNIVERSITY OF CALIFORNIA LIBRARY Los Angeles

This book is DUE on the last date stamped below.

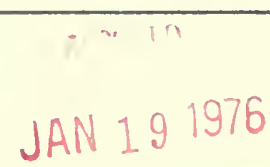

L.9-Series 444 
